\title{
Bruna Pereira de Morais
}

\section{"ESTUDO IN VITRO DO POTENCIAL DE DIFERENCIAÇÃO DAS CÉLULAS TRONCO IMATURAS DA POLPA DENTÁRIA HUMANA EM NEURÔNIOS RETINAIS"}

\begin{abstract}
Dissertação apresentada ao Programa de PósGraduação Interunidades em Biotecnologia USP/Instituto Butantan/IPT, para obtenção do Título de Mestre em Biotecnologia.
\end{abstract}




\title{
Bruna Pereira de Morais
}

\section{"ESTUDO IN VITRO DO POTENCIAL DE DIFERENCIAÇÃO DAS CÉLULAS TRONCO IMATURAS DA POLPA DENTÁRIA HUMANA EM NEURÔNIOS RETINAIS"}

\author{
Dissertação apresentada ao Programa de Pós- \\ Graduação Interunidades em Biotecnologia \\ USP/Instituto Butantan/IPT para obtenção do \\ Título de Mestre em Biotecnologia. \\ Área de concentração: Biotecnologia \\ Orientador: Prof $^{-}$Dr $^{-a}$ Irina Kerkis \\ Versão Original
}


DADOS DE CATALOGAÇÃO NA PUBLICAÇÃO (CIP)

Serviço de Biblioteca e Informação Biomédica do

Instituto de Ciências Biomédicas da Universidade de São Paulo

reprodução não autorizada pelo autor

Morais, Bruna Pereira de.

Estudo in vitro do potencial de diferenciação das células tronco imaturas da polpa dentária humana em neurônios retinais / Bruna Pereira de Morais. -- São Paulo, 2012.

Orientador: Profa. Dra. Irina Kerkis.

Dissertação (Mestrado) - Universidade de São Paulo. Instituto de Ciências Biomédicas. Programa de Pós-Graduação Interunidades em Biotecnologia USP/IPT/Instituto Butantan. Área de concentração: Biotecnologia. Linha de pesquisa: Células tronco.

Versão do título para o inglês: Study in vitro differentiation of human immature dental pulp stem cells into retinal neurons cells.

1. Células tronco imaturas da polpa dentária 2. Diferenciação in vitro 3. Retina 4. Neurônios retinais 5. Fotorreceptores 6. Terapia celular I. Kerkis, Profa. Dra. Irina II. Universidade de São Paulo. Instituto de Ciências Biomédicas. Programa de Pós-Graduação Interunidades em Biotecnologia USP/IPT/Instituto Butantan III. Título. 
Título da

Orientador(a):
Estudo in vitro do potencial de diferenciação das células tronco imaturas da polpa dentária humana em neurônios retinais.

Profa. Dra. Irina Kerkis.

A Comissão Julgadora dos trabalhos de Defesa da Dissertação de Mestrado, em sessão pública realizada a considerou
( ) Aprovado(a)
( ) Reprovado(a)
Examinador(a): Assinatura:
Nome:
Instituição:
Examinador(a): Assinatura:
Nome:
Instituição:
Presidente: Assinatura:
Nome:
Instituição:


Gostaria de dedicar mais esta vitória aos verdadeiros responsáveis por todas as vitórias da minha vida, meus amados pais, Adriana e Fernando, que nunca deixaram a base ruir, apesar de todas as adversidades da vida. Vocês são meus exemplos! Serei eternamente grata por tudo que passamos pra chegar até aqui!! 


\section{AGRADECIMENTOS}

À minha orientadora, Dra Irina Kerkis, por idealizar este projeto e pela incansável paciência de se sentar comigo na bancada sempre que as coisas não saíam como planejado! Obrigada por nunca me deixar desistir!

À meus queridos amigos e colegas de laboratório, Cris, Camila, Jéssica, Marília, Diana, Milena, Leandro, Dener, Ana, Paulo, André, e em especial para a Lis, Baby, Nelson e a muitos que neste tempo também já passaram por lá e se foram...Adoro a companhia de vocês. Obrigada de coração por tudo que me ensinaram nestes anos de convivência! Sem vocês nada teria dado certo!

Aos amigos da genética "do lado de lá", Rodrigo, Jack, Tati e pra minha querida Pri que nos "abandonou" mas que sempre estará presente. Foi muito bom contar com vocês nas horas boas e ruins!! Vocês também são especiais pra mim! Adorooooo!!

Dentre meus queridos amigos, gostaria de fazer um agradecimento especial à minha amiga do coração, Lis, que esteve comigo todos os dias olhando as culturas e me ajudando, tanto na parte prática, teórica, quanto no seu otimismo de que tudo ia sempre dar certo!! Dentro e fora do laboratório!! Obrigada de verdade por tudo que fez por mim esses anos!! Adoro você!!

Ao Dr. Alexandre Kerkis que está sempre por perto pra apoiar e auxiliar nossos projetos.

Ao Álvaro, que muitas vezes substituiu a Dra Irina sempre cuidando do laboratório com muito empenho e ao Alexandre Pereira que sempre me "pentelhou" (no bom sentido!), mas que esteve sempre lá pra me ajudar, principalmente com a impressão da tese.

A toda a equipe do laboratório de Genética que colaboraram para que tudo saísse da melhor maneira possível!

Ao Dr. José Álvaro, por ser colaborador deste projeto, com o qual pretendemos ainda ter grandes sucessos! Agradeço por deixar as portas da UNIFESP sempre abertas para mim.

Às agências de fomento, CNPq e FAPESP, por acreditarem neste trabalho e financiarem meus estudos.

A meus pais, Adriana e Fernando, por possibilitarem essa conquista. Tenho certeza que a base sólida que tenho em casa é a responsável pelo que sou hoje. "Sem vocês eu nada seria!!" 
À minha amiga irmã, Mônica, que me fez entender o quanto é bom ter uma irmã como companheira! Adoro ir pra casa quando você está lá, o fim de semana fica bem mais legal, rs!! E por ter me dado essa pessoinha tão especial que é minha sobrinha linda! Isa a tia te ama demais!

Ao meu namorado, amigo e companheiro, pelo apoio durante todos esses anos. Nada foi fácil pra mim, mas mesmo à distância, sentir o seu amor sempre me fez mais forte!! Te amo Ju!!

Às minhas amigas de todos os tempos e todas as horas, Mariana, Elaine e Luciana e à minha prima Carla, o meu "muito obrigada", por estarem sempre comigo, principalmente nas horas em que mais preciso do apoio de vocês!!

À minha família, que amo tanto, por todo o apoio incondicional que me deram! À minhas tias, Biga, Sofia e Lilia, à vovó Terezinha e ao vovô Morais, à vó Ude, à Dedei e ao Beto, e a todos que de uma maneira ou outra torceram por esta realização!! Família, vocês são as pessoais mais especiais da minha vida!! 
"Que os nossos esforços desafiem as impossibilidades. Lembrai-vos que as grandes proezas da história foram conquistadas do que parecia impossível".

Charles Chaplin 


\section{RESUMO}

MORAIS, B. P. Estudo in vitro do potencial de diferenciação das células-tronco imaturas da polpa dentária humana em neurônios retinais. 2012. 96 f. Dissertação (Mestrado em Biotecnologia) - Instituto de Ciências Biomédicas, Universidade de São Paulo, São Paulo, 2012.

Introdução: A retina é o tecido do olho, sensível à luz, que converte a energia captada em imagem através de células neuronais especializadas, as quais são consideradas células permanentes e portanto, quando danificadas são incapazes de se regenerar. Os tratamentos atuais visam apenas diminuir os danos na retina ao invés de promover uma recuperação eficaz da visão. Células-tronco (CT) são uma promissória fonte para substituir o tecido lesado. Células Tronco Imaturas da Polpa Dentária (CTIPD) apresentam características de CT pluripotentes e são capazes de se diferenciar em quase todos os tipos celulares. Objetivos: O nosso objetivo é avaliar o potencial de diferenciação das CTIPD em neurônios retinais, o que poderia representar uma nova fonte para o tratamento de doenças degenerativas da retina. Métodos: CTIPD indiferenciadas, previamente estabelecidas, foram analisadas por imunofluorescência para expressão de vimentina e de CD73, um marcador de precursor de fotorreceptores. Em seguida, estas células foram submetidas a formação de neuroesferas e a partir de então, à indução da diferenciação em neurônios retinais. A capacidade das CTIPD de se diferenciar em neuroesfera foi avaliada pela expressão de nestin, $\beta$-III-tubulin e Pax-6. A diferenciação retinal foi avaliada pela expressão dos marcadores específicos da diferenciação retinal: Pax-6, Chx-10, Crx, Nrl, Calbindin, Recoverin e Rhodopsin e novamente pelo CD73, agora pós-diferenciação. Resultados: As CTIPD indiferenciadas reagiram positivamente ao CD73 e vimentina. Observou-se também a reação positiva dos anticorpos anti-nestin e anti- $\beta$ III-tubulin na esfera, sugerindo um comprometimento com linhagem neural. Pax-6, um marcador de células progenitoras da retina, também foi positivo nas neuroesferas. Nas células diferenciadas a partir da neuroesfera, observamos com maior intensidade a expressão de Chx10, Crx e CD73 e com menor expressão, Nrl, Calbindin, Recoverin e Rhodopsin. Conclusão: Este estudo sugere que as CTIPD apresentam potencial de desenvolvimento de estruturas semelhantes à retinoesferas, com propriedades retinais e neurais in vitro, as quais podem ser induzidas à diferenciação em neurônios retinais. Nossos dados demonstraram que as CTIPD podem ser uma fonte alternativa para regenerar tecidos danificados da retina. Entretanto, estudos adicionais são necessários para elucidar a formação da retina neural.

Palavras-chave: Células tronco. Retina. Polpa dentária. Terapia celular. Retinopatias. 


\begin{abstract}
MORAIS, B. P. Study of in vitro differentiation of human immature dental pulp stem cells into retinal neurons cells. 2012. 96 p. Masters thesis (Biotechnology) - Instituto de Ciências Biomédicas, Universidade de São Paulo, São Paulo, 2012.

Introduction: Retina is the light-sensitive eye tissue which converts captured energy in image by specialized neuronal cells. If these cells are damaged they are unable to regenerate. Treatments aim only to decrease retinal damages instead of promoting an effective vision recovery. Stem cells (SC) are a promissive source to substitute injured tissue. Immature dental pulp stem cells (IDPSC) have characteristics of pluripotent SC and are able to acquire properties of almost all cell types. Objectives: We aim to evaluate the potential of IDPSC to develop retinal neurons, which can represent a new source for treatment of retinal degenerative diseases. Methods: Undifferentiated IDPSC, previously established by us, were analyzed by immunocytofluorescence to evaluate CD73 expression, an early photoreceptor marker. Further, these cells were submitted to progenitor neural differentiation. The capacity of IDPSC to differentiate towards retinal spheres similar structures was evaluated by the expression of Nestin, $\beta$-III-tubulin and Pax-6 antibodies. Retinal cells differentiation was perfomed from retinal spheres and was evaluated by the expression of specialized retinal neurons antibodies: Pax-6, Chx-10, Crx, Nrl, Calbindin, Recoverin and Rhodopsin. Results: Undifferentiated IDPSC reacted positively to CD73. We also observed the positive reaction of anti-nestin and anti- $\beta$-III-tubulin in retinal spheres, indicating that these structures have previous commitment with neural lineage. Anti-Pax-6, a marker of progenitor retina cells, was also positive in retinal spheres. Regarding other specialized retinal markers, they did not show any positive reaction in formed spheres. On the other hand, in differentiated cells from retinal spheres, we observed a high expression of Chx-10 and Crx, in comparison to Nrl, Calbindin, Recoverin and Rhodopsin, which were also positive but less intensive. We confirmed that CD73 was also expressed in these differentiated cells obtained from retinal spheres. Conclusion: This study suggests that IDPSC present the potential of developing retinal spheres structures, with neural and retinal properties in vitro, which can be induced to differentiate into retinal neurons. Our data demonstrated that IDPSC can be an alternative source to regenerate damaged retinal tissues. Nevertheless, it is still required some factors that can facilitate the induction of mature retinal characteristics. Further studies are needed in order to elucidate respective roles of retinal tissue formation.
\end{abstract}

Keywords: Stem cell. Retina. Dental pulp. Stem cell therapy. Degenerative retinopathies. 


\section{LISTA DE ILUSTRAÇÕES}

Figura 1 - Estruturas do Olho Humano ................................................................ 22

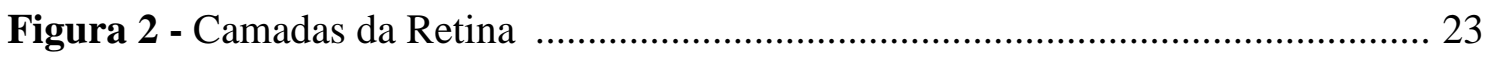

Figura 3 - Degeneração Macular Relacionada à Idade............................................... 26

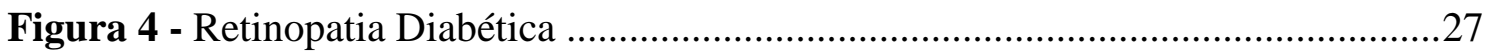

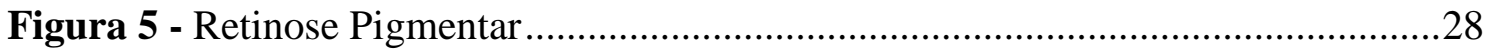

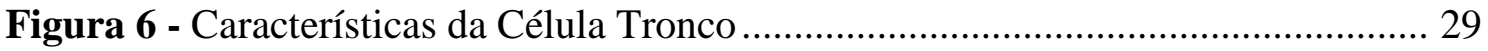

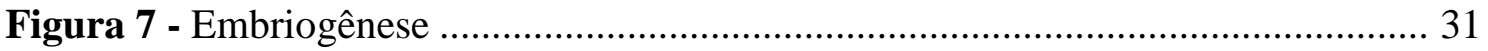

Figura 8 - Etapas da Diferenciação das CTIPD em Neurônios Retinais-símile ............. 46

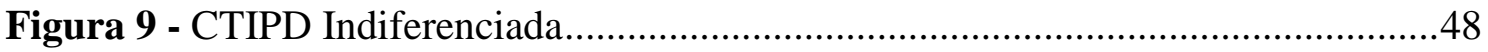

Figura 10 - Células do Epitélio Pigmentar da Retina .................................................49

Figura 11 - Imunofluorescência - CTIPD Indiferenciadas .........................................5 50

Figura 12 - Imunofluorescência - CTIPD Indiferenciadas - Marcadores Retinais........ 51

Figura 13 - Citometria de Fluxo - CTIPD Indiferenciadas ........................................ 52

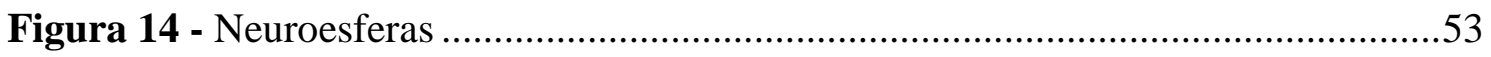

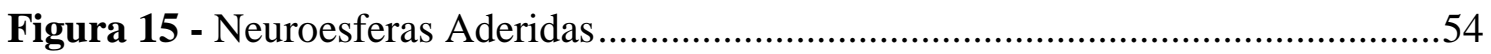

Figura 16 - Microscopia Eletrônica de Transmissão.................................................. 55

Figura 17 - Neuroesferas Aderidas - Meio de Diferenciação......................................... 56

Figura 18 - Coloração das Neuroesferas com Hematoxilina/Eosina.............................. 57

Figura 19 - Imunofluorescência - Neuroesferas ........................................................ 58

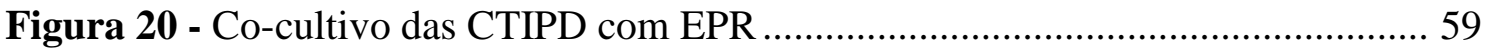

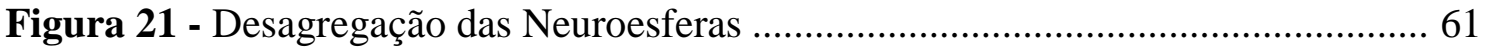

Figura 22 - Diferenciação Direta das CTIPD em Células Neural-like.......................... 63

Figura 23 - Diferenciação das Neuroesferas em Neurônios Retinais ............................ 65

Figura 24 - Diferenciação das Neuroesferas em Neurônios Retinais - Rosetas ............ 67

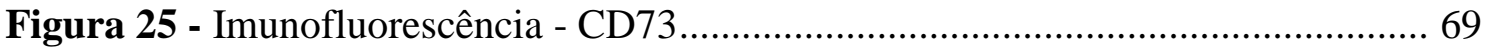




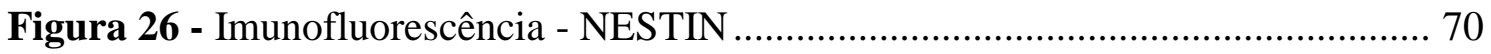

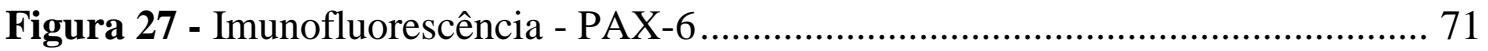

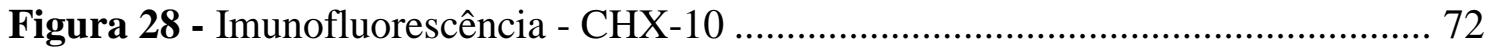

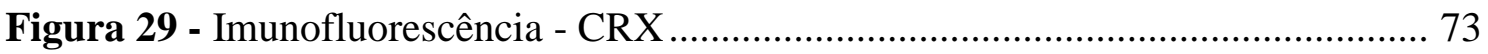

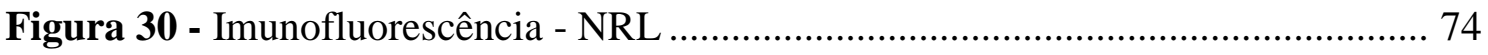

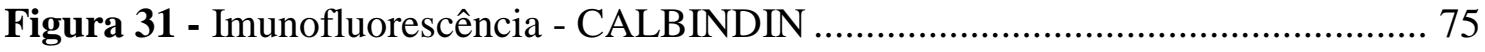

Figura 32 - Imunofluorescência - RECOVERIN ….................................................. 76

Figura 33 - Imunofluorescência - RHODOPSIN ......................................................... 77

Figura 34 - Marcadores Expressos Durante o Desenvolvimento Ocular .......................82 


\section{LISTA DE QUADROS}

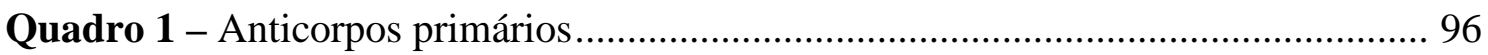

Quadro 2 - Anticorpos primários - Precursores neurais .......................................... 96

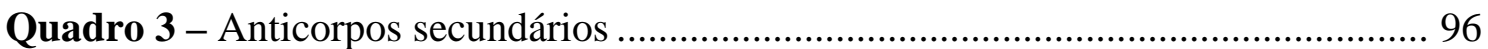




\section{LISTA DE ABREVIATURAS}

ANE

AR

ARPE-19

BSA

CASO

CD73

CD90

CD105

Chx-10

CONEP

Crx

CT

CTA

CTCN

CTE

CTIPD

CTPD

CTM

DAPI

$\mathrm{DL}$

DMEM-F12

DMRI
Aminoácidos não-essenciais

Ácido retinóico

do inglês "Adult Retinal Pigment Epithelium"

do ingles "Bovine Serum Albumin"

Centro Avançado de Superfície Ocular

do inglês "Clusters of Differentiation"

do inglês "Clusters of Differentiation"

do inglês "Clusters of Differentiation"

do inglês "homeobox-containing transcription factor"

Comissão Nacional de Ética em Pesquisa

do inglês "Cone-rod homeobox"

Célula Tronco

Células Tronco Adultas

Células Tronco da Crista Neural

Células Tronco Embrionárias

Células Tronco Imaturas da Polpa Dentária

Células Tronco da Polpa Dentária

Células Tronco Mesenquimais

do inglês "4'6-Diamidino-2-phenylindol"

Dente de Leite

do inglês "Dulbecco's Modified Eagle's Medium-Ham's F12"

Degeneração Macular Relacionada à Idade 
EPR

FACS

FGF

GFAP

HE

iPS

$\mathrm{Nrl}$

Oct-4

OMS

Pax-6

PBS

$\mathrm{RD}$

$\mathrm{RP}$

RPM

SFB

SNC

SSEA-3/SSEA-4

TBS

TRA-1-61/1-81

UNIFESP
Epitélio Pigmentar da Retina

do inglês "fluorescence-activated cell sorter"

do inglês "Fibroblast Grown Factor"

do inglês "Glial Fibrillary Acidic Protein"

Hematoxilina/Eosina

do inglês "Induced Pluripotent Stem Cells"

do inglês "Neural retina-specific leucine zipper"

do inglês "Octamer binding transcription factor 4"

Organização Mundial da Saúde

do inglês "Paired box 6"

do inglês "Phosphate-Buffered Saline"

Retinopatia Diabética

Retinose Pigmentar

Rotação por minuto

Soro Fetal Bovino

Sistema Nervoso Central

do inglês "specific-stage embrionic antigen"

do inglês "Tween Buffered Saline"

do inglês "Tetracarcinoma Antigen"

Universidade Federal do Estado de São Paulo 


\section{SUMÁRIO}

1 INTRODUÇÃ

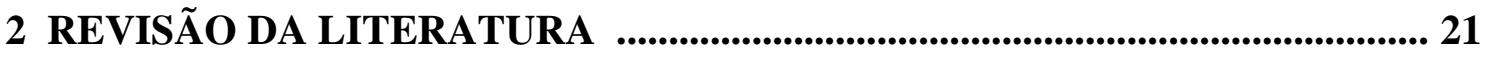

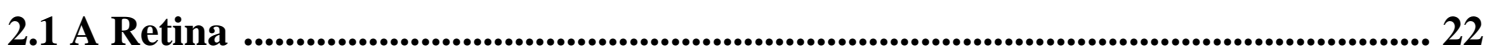

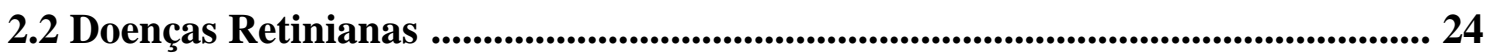

2.3 Degeneração Macular Relacionada à Idade ........................................................ 25

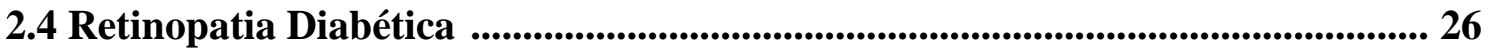

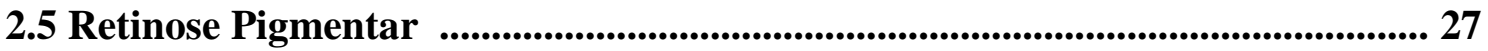

2.6 Fisiologia das Degenerações Retinianas ................................................................. 28

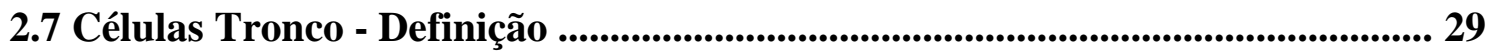

2.8 Células Tronco Adultas...............................................................................................31

2.9 Células Tronco Imaturas da Polpa Dentária (CTIPD) ..................................... 32

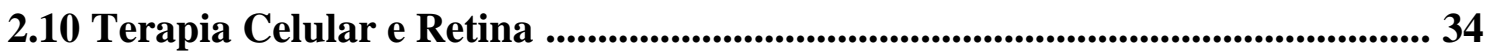

2.11 Células Tronco Imaturas da Polpa Dentária e Retina ...................................... 36

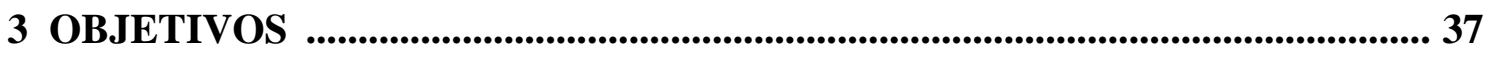

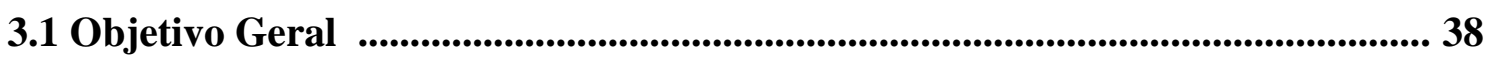

3.2 Objetivos Específicos ................................................................................... 38

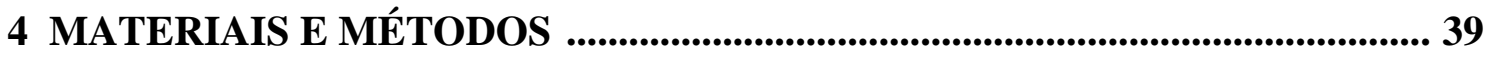

4.1 Células Tronco Imaturas da Polpa Dentária ..............................................................40

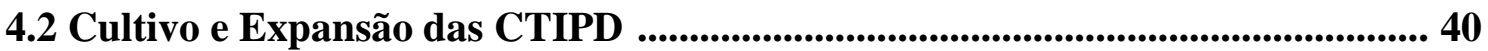

4.3 Cultivo e Expansão das Células do Epitélio Pigmentar da Retina (EPR) ........ 40

4.4 Caracterização .....................................................................................................................................41

4.4.1 Imunofluorescência ......................................................................................................... 41

4.4.2 Citometria de Fluxo .................................................................................. 41

4.5 Diferenciação das CTIPD em Neuroesferas ......................................................... 42

4.6 Transferência das Neuroesferas ..................................................................... 42 
4.7 Microscopia Eletrônica de Transmissão. .42

4.8 Diferenciação das Neuroesferas em Progenitores Retinais ..................................... 43

4.9 Co-cultivo das Neuroesferas com Células do EPR ......................................... 43

4.10 Desagregação das Neuroesferas ................................................................... 44

4.11 Diferenciação das CTIPD em Neurônios Retinais............................................. 44

4.12 Diferenciação das Neuroesferas em Neurônios Retinais........................................ 45

4.13 Imunofluorescência nas Neuroesferas Diferenciadas em Neurônios Retinais 46

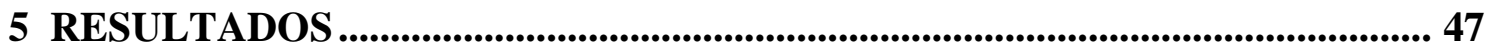

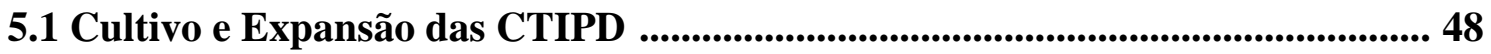

5.2 Cultivo e Expansão das Células Epiteliais da Retina ......................................... 48

5.3 Caracterizaçãa das CTIPD ........................................................................................... 49

5.3.1 Imunofluorescência .......................................................................................................... 49

5.3.2 Imunofluorescência - Marcadores retinais ..................................................... 50

5.3.3 Citometria de Fluxo (FACS) ........................................................................ 51

5.4 Diferenciação das CTIPD .................................................................................. 53

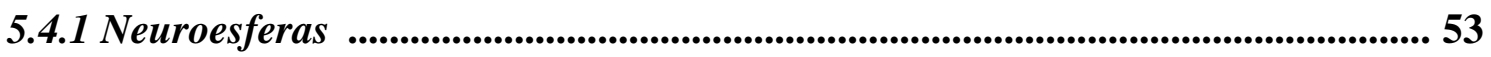

5.4.2 Adesão das Neuroesferas ..................................................................................... 54

5.4.3 Microscopia Eletrônica de Transmissão .........................................................55

5.4.4 Coloração das Neuroesferas com Hematoxilina/Eosina .................................... 56

5.4.5 Imunofluorescência nas Neuroesferas .......................................................... 57

5.4.6 Co-cultivo das CTIPD com Células do EPR ..................................................... 58

5.4.7 Desagregação das Neuroesferas ............................................................................. 59

5.4.8 Diferenciação Direta das CTIPD em Células Neural-like ................................62

5.4.9 Diferenciação das Neuroesferas em Neurônios Retinais....................................64

5.4.10 Imunofluorescência - Avaliação das Células Diferenciadas ..............................68

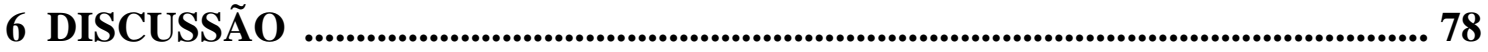




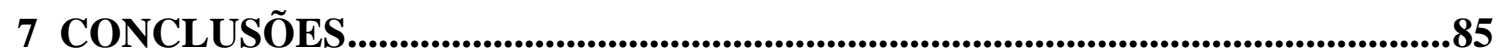

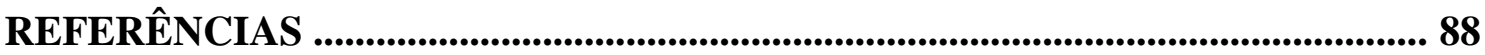

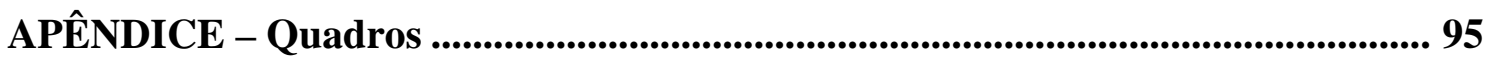


1 INTRODUÇÃO 
A deficiência visual, que pode ser definida como cegueira ou baixa visão, atinge atualmente, segundo estimativas da Organização Mundial da Saúde (OMS), 180 milhões de pessoas, sendo 45 milhões de pessoas com cegueira e 135 milhões de pessoas com baixa visão (RESNIKOFF et al., 2004). Tanto a deficiência visual quanto a cegueira causam um impacto significativo no desenvolvimento socioeconômico do país. Suas consequências são um grave problema de saúde pública com maior impacto nos países em desenvolvimento, onde está concentrada cerca de $80 \%$ da cegueira mundial (CONGDON; FRIEDMAN; LIETMAN, 2003). Na América Latina, estimam-se cerca de 7 a 10 milhões de indivíduos com baixa visão. Estima-se ainda que, só no Brasil, existem mais de 1 milhão de pessoas com algum tipo de deficiência visual e aproximadamente 357 mil cegos, segundo estudo realizado por Salomão, Mitsuhiro e Belfort Junior (2009).

Lesões em neurônios da retina podem acometer pacientes de qualquer idade, raça, sexo e classe social, e são de extrema gravidade devido ao fato destes neurônios serem células permanentes, ou seja, não possuem a capacidade de autorrenovação devido ao seu estado altamente especializado. Assim, uma vez danificados perde-se permanentemente a capacidade de regeneração (CHIOU et al., 2005). Embora as degenerações retinianas possam acometer toda a população, existem grupos mais susceptíveis a tais doenças, como por exemplo, pacientes idosos, diabéticos, portadores de doenças genéticas relacionadas à retina, entre outros. Na Degeneração Macular Relacionada à Idade (DMRI), como o próprio nome sugere, o principal fator para o desenvolvimento da doença, é a idade. Logo, o aumento na expectativa de vida da população tende a aumentar a incidência dessa enfermidade nos próximos anos. Dados da OMS (2004) mostram que o Brasil terá a sexta população de idosos no mundo até 2025. Para portadores do diabetes, num curso de 20 anos da doença, aproximadamente $99 \%$ dos pacientes tipo I e $65 \%$ dos pacientes tipo II, serão afetados por algum grau da Retinopatia Diabética (DURRUTY et al., 2000). A Retinose Pigmentar (RP) constitui um grupo de doenças da retina com caráter de degeneração gradativa das células da retina sensíveis à luz. A RP é causada por inúmeras mutações genéticas, hereditárias e ainda relacionada a fatores ambientais (estresse, tabagismo, medicamentos, etc.). Pessoas afetadas podem ter dificuldade de enxergar em locais com pouca luminosidade ou claridade excessiva e perdem progressivamente a visão periférica ou a visão noturna levando a cegueira irreversível. Os portadores desta doença perdem em média até 7,7\% do seu campo visual por ano. Dados do Conselho Brasileiro de Oftalmologia apontam que cerca de 40 mil pessoas sofrem com esta doença no País. 
Atualmente, os tratamentos existentes para as degenerações retinianas permitem apenas evitar a progressão das doenças ou em casos de detecção precoce, prevenir algum tipo de lesão futura. Porém, estes tratamentos são de elevado custo e risco para o paciente, já que são terapias de alta tecnologia e invasivas. Uma alternativa que vem ganhando grande enfoque nos dias atuais é o uso de células tronco para o tratamento de doenças consideradas até então incuráveis. As células tronco, por apresentarem capacidade de diferenciação para qualquer tipo celular funcional e serem capazes de quando reintroduzidas num organismo, se integrar no tecido lesado, apresentam-se como um potencial tratamento para a cura dos pacientes com degenerações retinianas por meio da regeneração tecidual.

Levando em consideração a enorme quantidade de pacientes que apresentam algum tipo de deficiência visual por problemas na retina e o fato de que um tratamento realmente efetivo na recuperação da visão poderia beneficiá-los, temos por objetivo neste trabalho, desenvolver um método eficiente para a diferenciação das células tronco de polpa dentária humana em neurônios retinais, visando sua futura aplicação clínica em lesões retinianas. 
2 REVISÃO DA LITERATURA 


\subsection{A Retina}

A retina é o tecido do olho sensível à luz que converte o estímulo luminoso em impulso elétrico, através de células altamente especializadas, os fotorreceptores. Estes por sua vez, enviam um estímulo nervoso ao cérebro via nervo óptico, possibilitando o sentido da visão. A retina localiza-se principalmente no fundo do olho e está anteriormente limitada pelo humor vítreo e posteriormente pela coróide.

Figura 1 - Estruturas do Olho Humano

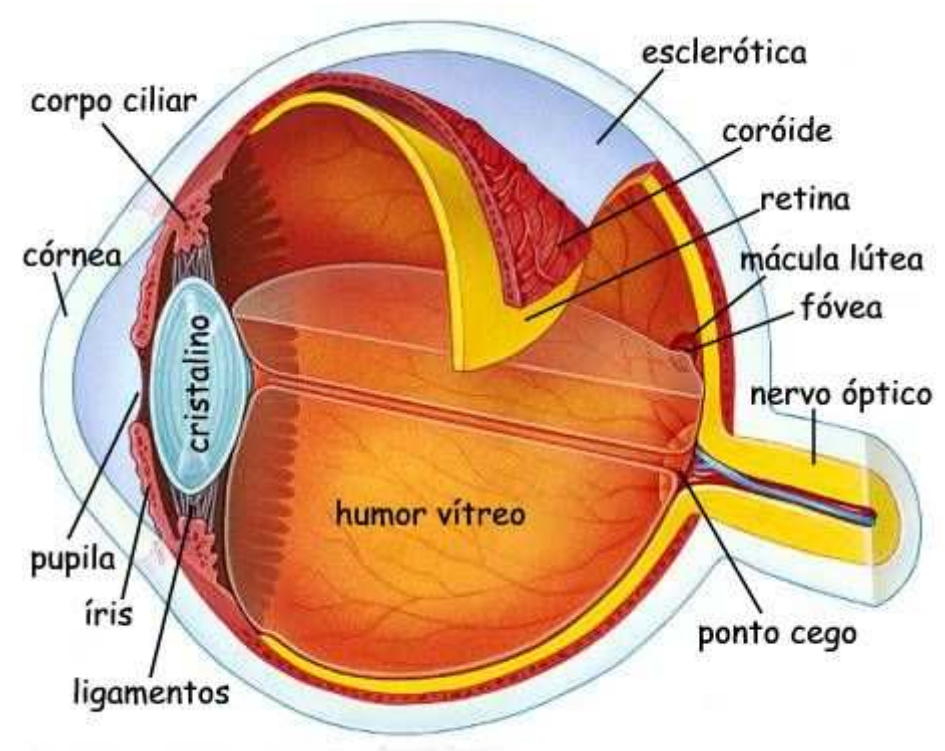

Ilustração das principais estruturas que compõe o olho humano.

Fonte: Grupo Retina São Paulo, 2007.

Embriologicamente, a retina é composta de duas camadas de origem neuroectodérmica: epitélio pigmentar da retina $(E P R)$ e retina neurossensorial, a qual é dividida em mais nove camadas, completando as dez camadas da retina. As camadas, desde o EPR até o vítreo (da mais externa para a mais interna), são: camada de fotorreceptores, membrana limitante externa, camada nuclear externa, camada plexiforme externa, camada nuclear interna, camada plexiforme interna, camada de células ganglionares, camada de fibras nervosas e membrana limitante interna (SCHUBERT, 2004), como mostrado na Figura 2. 
Figura 2 - Camadas da Retina

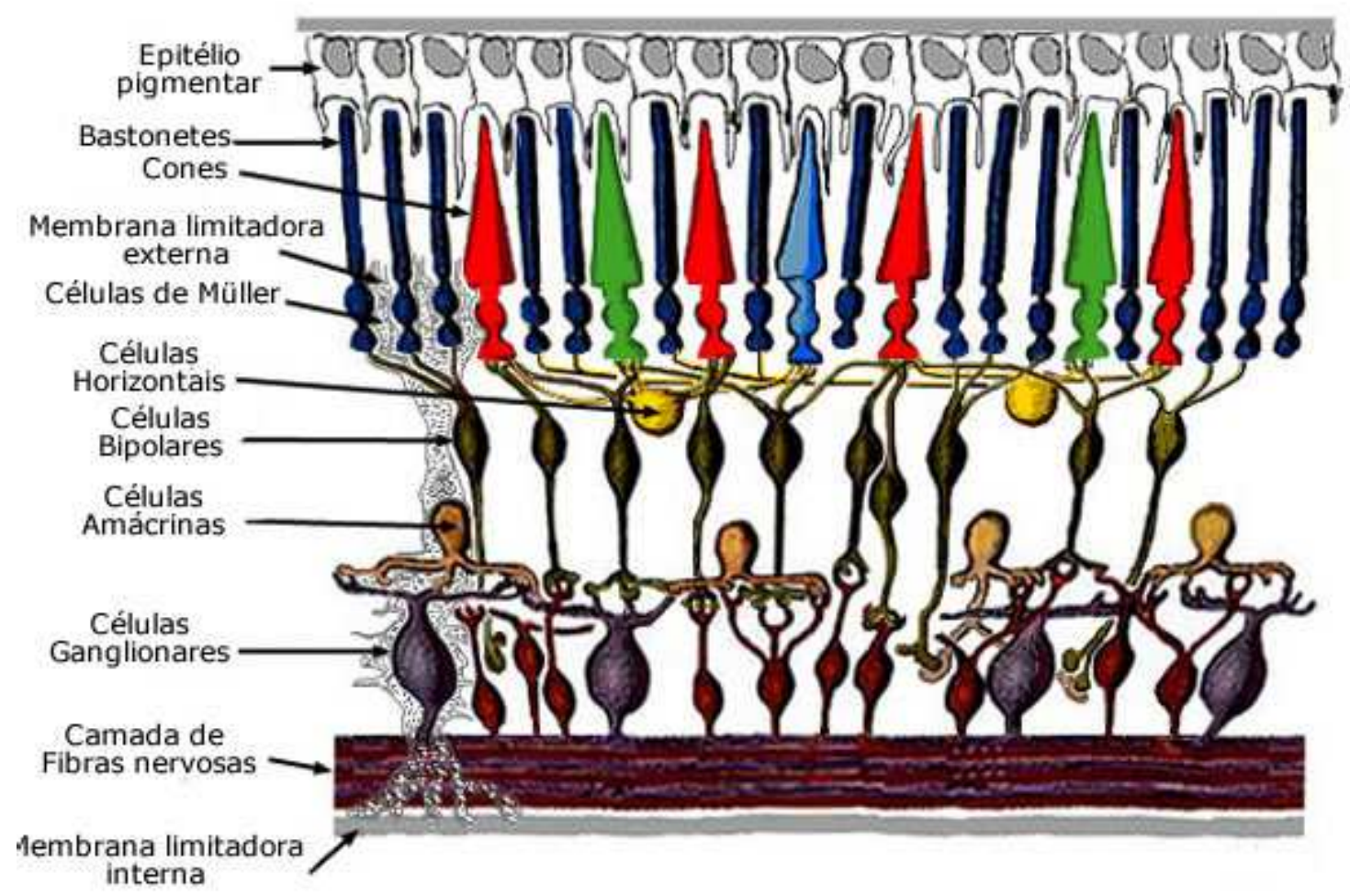

Esquema ilustrativo das camadas que compõe a retina.

Fonte: Meldau, 2010.

O EPR é composto por melanina e está em contato, mais externamente, com a coróide. É o responsável pela manutenção da barreira entre os vasos da coróide e a retina neurossensorial. Tem função de bomba de íons e osmótica, aumentando a aderência e a resistência ao descolamento de retina. Também tem função de reciclagem da camada externa dos fotorreceptores através da fagocitose dos restos celulares e de repor a vitamina A utilizada após estímulo luminoso (MARMOR, 2004; SLATTER, 2005).

Os fotorreceptores são neurônios sensíveis à luz e que podem ser divididos em dois grupos: cones ou bastonetes. A região central da retina, denominada mácula ou fóvea, responsável pela visão mais acurada é composta principalmente por cones, os quais também são responsáveis pela visão das cores. Já o restante da retina é composto basicamente por bastonetes, encarregados da percepção de claro/escuro (SCHUBERT, 2004).

As células gliais de Muller, com funções principais de sustentação e metabolismo dos íons e restos celulares da retina, estão situadas desde a membrana limitante externa até a limitante interna (SCHUBERT, 2004). 
A camada nuclear externa contém os núcleos dos fotorreceptores. A plexiforme externa é a região de sinapse entre os fotorreceptores e as células bipolares (neurônios de $1^{\text {a }}$ ordem). Na camada nuclear interna, situam-se os núcleos das células bipolares, horizontais, de Müller e amácrinas. As células horizontais e amácrinas são interneurônios que modulam a transmissão nervosa (SCHUBERT, 2004).

$\mathrm{Na}$ camada plexiforme interna, estão as sinapses entre as células da camada nuclear interna e as células ganglionares (neurônios de $2^{\mathrm{a}}$ ordem). Na camada das fibras nervosas, estão os axônios das células ganglionares, que se unem para formar o nervo óptico. A camada limitante interna recobre as fibras nervosas e tem contato direto com o vítreo (SCHUBERT, 2004).

As primeiras células produzidas na retina em desenvolvimento são as células ganglionares, seguidas pelos cones e células amácrinas. Posteriormente, surgem as células horizontais e os bastonetes. Por último, as células bipolares e de Müller (LIVESEY; CEPKO, 2001).

Após um estímulo visual, todos os neurônios da retina sofrem uma complexa cascata de interações neurais através de caminhos sinápticos, os quais finalmente transportam para o cérebro as mensagens visuais, por meio das células ganglionares via nervo óptico. Este processo complexo requer conexões intactas dos axônios, as quais são perdidas em processos degenerativos da retina. Uma potencial restauração da função visual depende criticamente do restabelecimento da dinâmica deste caminho neural (SIQUEIRA, 2009).

\subsection{Doenças Retinianas}

As degenerações retinianas podem ser divididas em dois grandes grupos: aquelas que afetam as camadas externas da retina e aquelas que afetam as camadas internas. Em geral, as patologias que afetam a camada mais externa da retina, resultam na perda dos neurônios fotorreceptores, enquanto as patologias que afetam as camadas mais internas podem afetar ambas as células bipolares e ganglionares. As doenças mais comuns que causam a perda da camada de fotorreceptores são respectivamente a degeneração macular relacionada à idade (DMRI) e a retinose pigmentar (RP), podendo ainda causar a perda ou disfunção do EPR. Uma das causas principais das degenerações nas camadas internas da retina são as isquemias retinianas, nas quais ocorre uma privação de oxigênio e nutrientes na vascularização retinal, levando à morte das células bipolares e ganglionares. Dentre as isquemias, a retinopatia 
diabética (RD) é a mais comum, seguida da retinopatia da prematuridade e oclusões vasculares (BULL; MARTIN, 2011).

Ambos os grupos de patologias degenerativas retinianas podem ser passíveis de terapia com células tronco, pois a diferenciação em neurônios retinais não se limita a um tipo exclusivo de neurônio, podendo, portanto, regenerar uma ou outra camada da retina (CHIOU et al., 2005).

\subsection{Degeneração Macular Relacionada à Idade}

A DMRI é uma doença da retina que atinge a mácula, ou seja, a região do olho responsável pela visão central. Acomete principalmente pacientes com mais de 55 anos de idade, sendo o principal sintoma a perda gradual da visão central como mostrado na figura 3. Alguns pacientes observam distorção da imagem, como também manchas na visão. Sua prevalência varia de $0,05 \%$ entre os mais jovens que 50 anos e 11,8\% após os 80 anos de idade (HOPLEY et al., 2004). Existe também uma forma de degeneração macular juvenil, conhecida como doença de Stargardt, a qual se desenvolve de maneira muito semelhante à DMRI. A DMRI ocorre devido ao acúmulo de substâncias residuais na retina, causando uma degeneração retiniana e consequentemente, morte das células retinianas neste local. $\mathrm{O}$ principal mecanismo fisiopatológico envolvido é a disfunção do epitélio pigmentar da retina (EPR), o qual exerce funções essenciais de nutrição e sustentação para os neurônios da retina. Secundariamente, ocorre a perda propriamente da função dos fotorreceptores (de Jong, 2006). Atualmente, não existe tratamento profilático e o uso de antioxidantes e complementos vitamínicos é muito discutível. A fotocoagulação com laser de argônio, a cirurgia retiniana e, mais recentemente, a terapia fotodinâmica são opções de tratamento para casos selecionados. Porém estes tipos de tratamentos visam apenas retardar a perda visual dos pacientes que em longo prazo será inevitável. E não se pode deixar de citar ainda, o fato de serem tratamentos invasivos e de rotina, causando riscos à saúde e desconforto ao paciente. 
Figura 3 - Degeneração Macular Relacionada à Idade

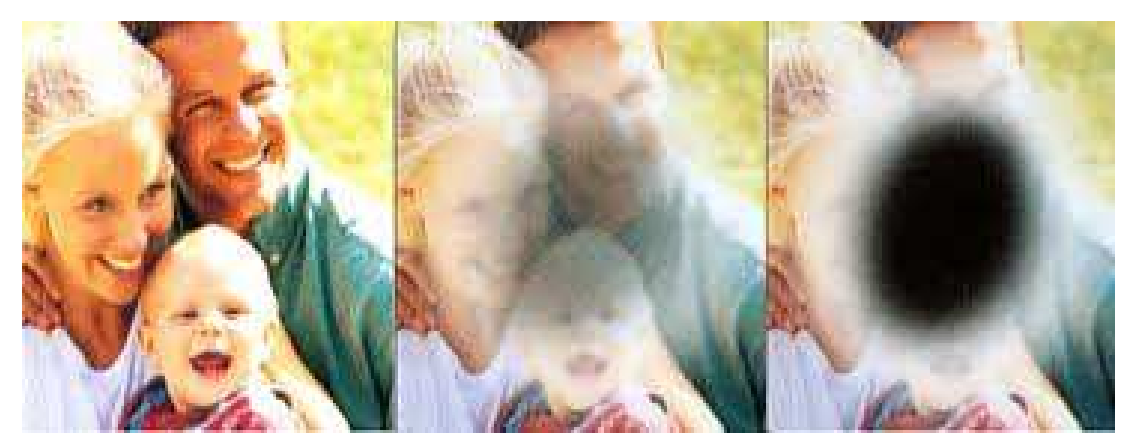

Perda progressiva da visão central em pacientes portadores de DMRI.

Fonte: Isoolhos, 2005.

\subsection{Retinopatia Diabética}

A Retinopatia Diabética (RD) é caracterizada por alterações ou danos vasculares, os quais causam lesões isquêmicas na retina, podendo causar uma neovascularização patológica e, como consequência, a perda da acuidade visual. O paciente passa a enxergar pontos desfocados no campo visual (Figura 4). Uma das complicações microvasculares mais importantes do diabetes mellitus é a RD. No Brasil, estima-se que metade dos pacientes portadores de diabetes seja afetada pela RD, sendo responsável por $7,5 \%$ das causas de incapacidade dos adultos para o trabalho. A prevalência de todos os tipos de retinopatia em diabéticos aumenta com a duração da doença. Após 20 anos de doença, aproximadamente $99 \%$ dos portadores de diabetes tipo 1 e $60 \%$ dos tipo 2 tem algum grau de RD. Em relação à isquemia, se esta ocorrer na região macular, o paciente rapidamente experimentará perda da visão e/ou do campo visual, e se ocorrer na periferia, o estímulo a proliferação de neovasos pode causar sangramento intraocular e descolamento de retina e conseqüentemente, cegueira. A RD tem a tendência de progredir com o tempo, causando maior lesão retiniana anatômica e funcional e, consequentemente, perda visual total (DURRUTY et al., 2000). 
Figura 4 - Retinopatia Diabética

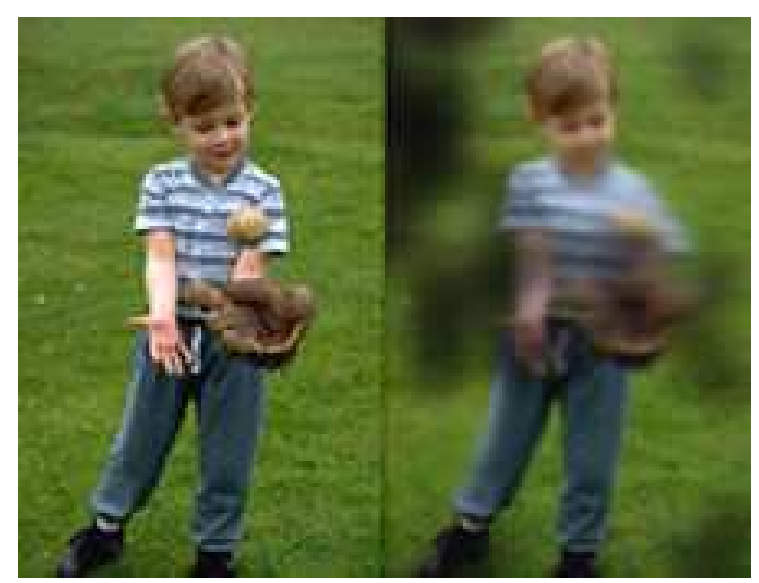

Visão de paciente normal (esquerda) e portador de RD (direita).

Fonte: Conselho Brasileiro de Oftalmologia, 2003.

\subsection{Retinose Pigmentar}

A retinose pigmentar é uma degeneração progressiva dos fotorreceptores retinianos, que são as células sensíveis à luz. O paciente irá perceber alterações do seu campo visual, dificuldade de adaptação ao escuro (cegueira noturna) e diminuição da visão. Ela é hereditária, embora em $42 \%$ dos casos não possamos confirmar a presença familiar da doença. Estima-se que no Brasil existem cerca de 40.000 pessoas com RP. Atinge hoje, um em cada cinco a sete mil recém-nascidos. E se manifesta até os 20 anos de idade. Costuma aparecer entre os 10 e 20 anos, mas pode surgir mais cedo. Existe ainda uma forma mais grave da doença, a RP congênita, também conhecida como Amaurose Congênita de Leber. As primeiras alterações do campo visual são a cegueira noturna e a perda da visão, da periferia para o centro do campo visual. Geralmente, a visão frontal (central) permanece boa até as fases tardias da doença (Figura 5). A retinose pigmentar ainda não tem cura, e o que se tenta é retardar a sua progressão, com o uso de palmitato de vitamina A. Existe também em Cuba, algumas tentativas de impedir o desenvolvimento da doença com estimulação elétrica da retina e ozonização do sangue, mas que não tem mostrado qualquer melhora à função visual e que ainda, em muitos casos, pode atuar desfavoravelmente, agravando o curso da doença (VECINO, 2008). 
Figura 5 - Retinose Pigmentar

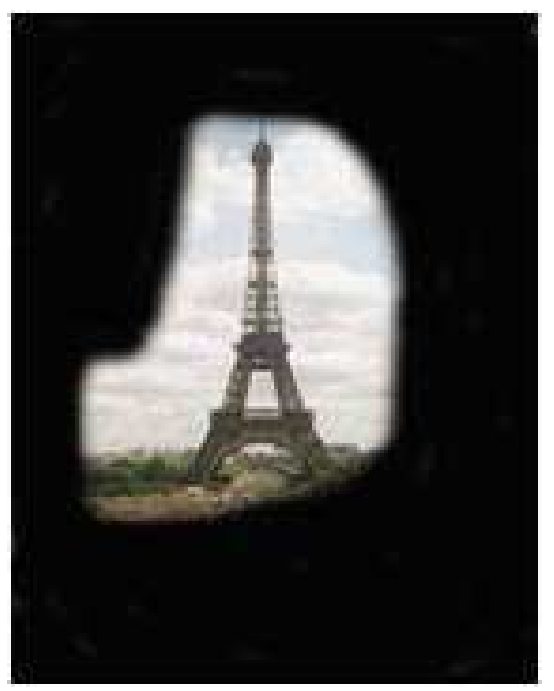

Visão de paciente portador de RP com perda da visão periférica.

Fonte: Sieiro, 2006.

\subsection{Fisiologia das Degenerações Retinianas}

Em mamíferos, o reparo retiniano decorrente de uma lesão local, apresenta várias etapas que consistem em uma série de mudanças características no local da lesão e que resultam ao seu final em mudanças degenerativas progressivas e a formação de tecido cicatricial-gliose. Essas etapas são conhecidas como aguda, subaguda e crônica (LEWIS et al., 2003; POZDNYAKOV et al., 2008).

A fase aguda, que ocorre nas primeiras horas após a lesão, é caracterizada por hemorragia e pelo início de cascatas de morte celular. Além disso, estudos morfológicos mostram que também ocorre uma completa desorganização estrutural e funcional de todas as camadas da retina. A fase subaguda é caracterizada por uma reação inflamatória generalizada na qual, células lesadas liberam citocinas pró-inflamatórias que além de serem neurotóxicas, recrutam componentes do sangue periférico. Ainda há desorganização estrutural total da retina. Com 6 a 7 dias, após a lesão, a inflamação e a proliferação celular cessam e se inicia a fase crônica (BRINGMANN; REICHENBACH, 2001). Durante a fase tardia, as células que migraram para o local da lesão substituem parte da hemorragia por membranas fibrovasculares que podem se retrair, causando problemas severos como, por exemplo, o descolamento retiniano (RYAN; STOUT; DUGEL, 1994). 
Na tentativa de prevenir o processo degenerativo, tratamentos como fotocoagulação focal com laser, uso de drogas antiangiogênicas e até mesmo intervenções cirúrgicas são utilizadas como paliativos. No entanto, tais tratamentos são capazes de somente adiar a perda visual, que em longo prazo é inevitável. Nesse sentido, alternativas de tratamento têm surgido a partir de recentes descobertas no campo das células tronco, ampliando as perspectivas da aplicação de terapias celulares para regenerar tecidos oculares lesados irreversivelmente por alguma doença.

\subsection{Célula Tronco - Definição}

A célula tronco $(\mathrm{CT})$ é uma célula que possui três características fundamentais que a distinguem de outros tipos celulares. Primeiro, são células indiferenciadas, ou seja, não comprometidas com nenhuma linhagem celular. Segundo, são células com capacidade de autorrenovação, gerando células-filhas idênticas à célula-mãe. E por fim, sob certas condições fisiológicas ou experimentais, podem ser induzidas a diferenciar-se, ou seja, tornarem-se células com funções especializadas (ALVARADO, 2008).

Figura 6 - Características da Célula Tronco

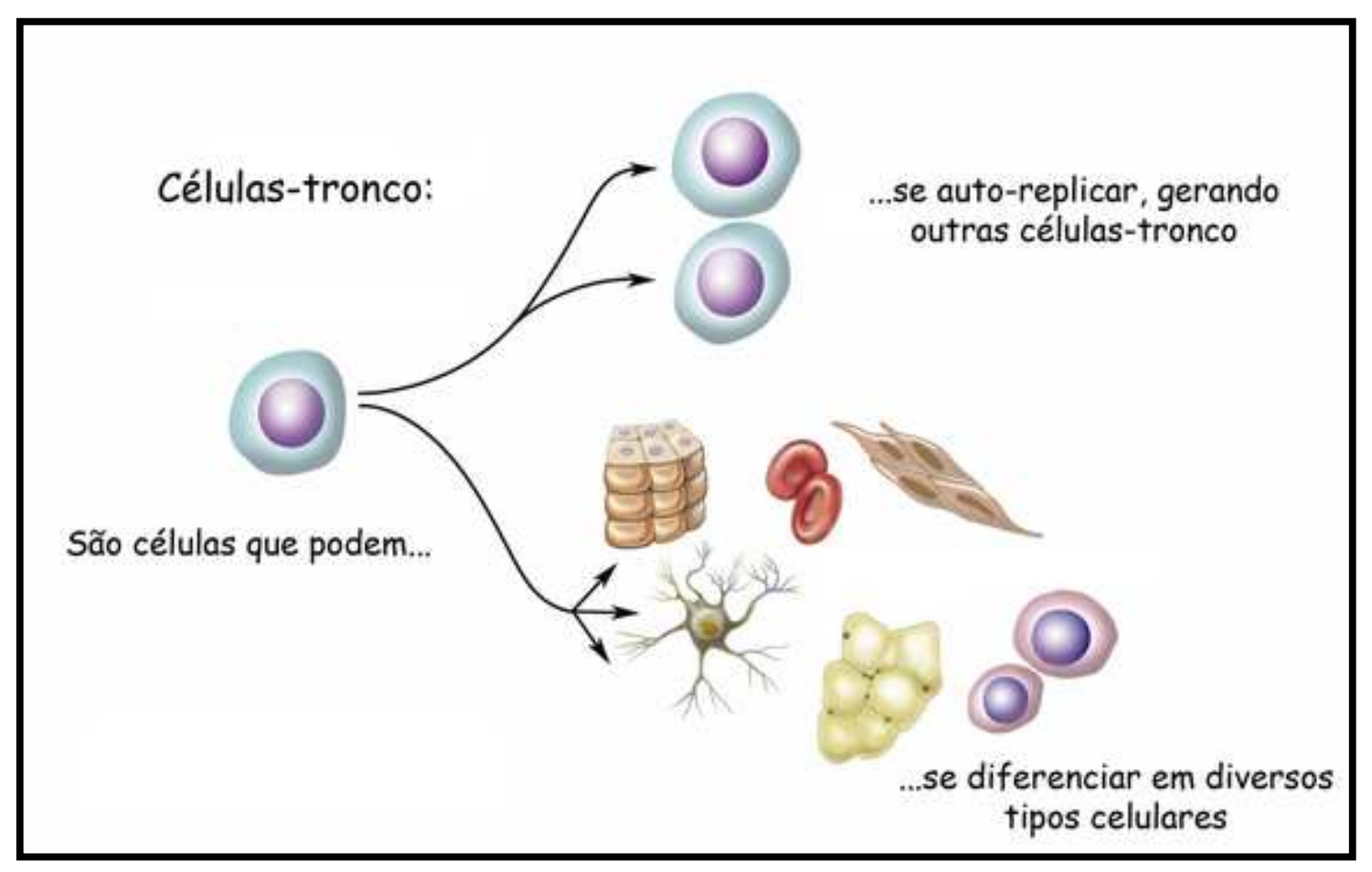

Propriedades das células tronco.

Fonte: Lance, 2010. 
As células tronco, de acordo com sua origem, podem ser classificadas em:

- Adultas: Mais comumente, as células-tronco adultas (CTA) são isoladas de tecidos de origem embrionária mesodermal, como medula óssea (CAPLAN, 1991), tecido adiposo (NAKAGAMI et al., 2005; ZUK et al., 2001, 2002), cordão umbilical (MARKIEWICZ et al., 2011) e músculo (BRACK et al., 2007), e são denominadas células tronco mesenquimais (CTM). Porém, podem ser obtidas de qualquer tecido do corpo, como pele (FRYE; FISHER; WATT, 2007), tecido nervoso (DE FILIPPIS et al., 2007), polpa dentária (KERKIS et al., 2006), entre outros;

- Embrionárias: são obtidas somente a partir da massa celular interna do blastocisto (THOMSON et al., 1998).

Em relação à sua capacidade de diferenciação em outros tipos celulares, as células tronco podem ser classificadas em:

- Totipotentes: são células capazes de diferenciarem-se em todos os 216 tecidos que formam o corpo humano, incluindo a placenta e anexos embrionários. As células totipotentes são encontradas nas primeiras fases de divisão celular após a fecundação, isto é, quando o embrião tem até 16 células, o que corresponde a 3 ou 4 dias de vida;

- Pluripotentes: são células capazes de diferenciarem-se em quase todos os tecidos humanos, exceto placenta e anexos embrionários. Tais células são obtidas a partir da massa celular interna do blastocisto, aproximadamente a partir do $5^{\circ}$ dia após a fecundação. As células internas do blastocisto são pluripotentes e são denominadas células tronco embrionárias (CTE), enquanto as células da membrana externa destinam-se a produção da placenta e às membranas embrionárias;

- Multipotentes: são células capazes de diferenciarem-se em alguns tecidos do corpo humano, mas com potencial reduzido em relação às células tronco pluripotentes. São denominadas CTA e podem ser encontradas em quase todos os tecidos do corpo;

- Oligopotentes: são células que embora já comprometidas com uma linhagem celular, ainda possuem um potencial de diferenciação em tipos celulares diferentes dentro daquela mesma linhagem. Um exemplo de células oligopotentes são as células precursoras ou progenitoras. 
Figura 7 - Embriogênese

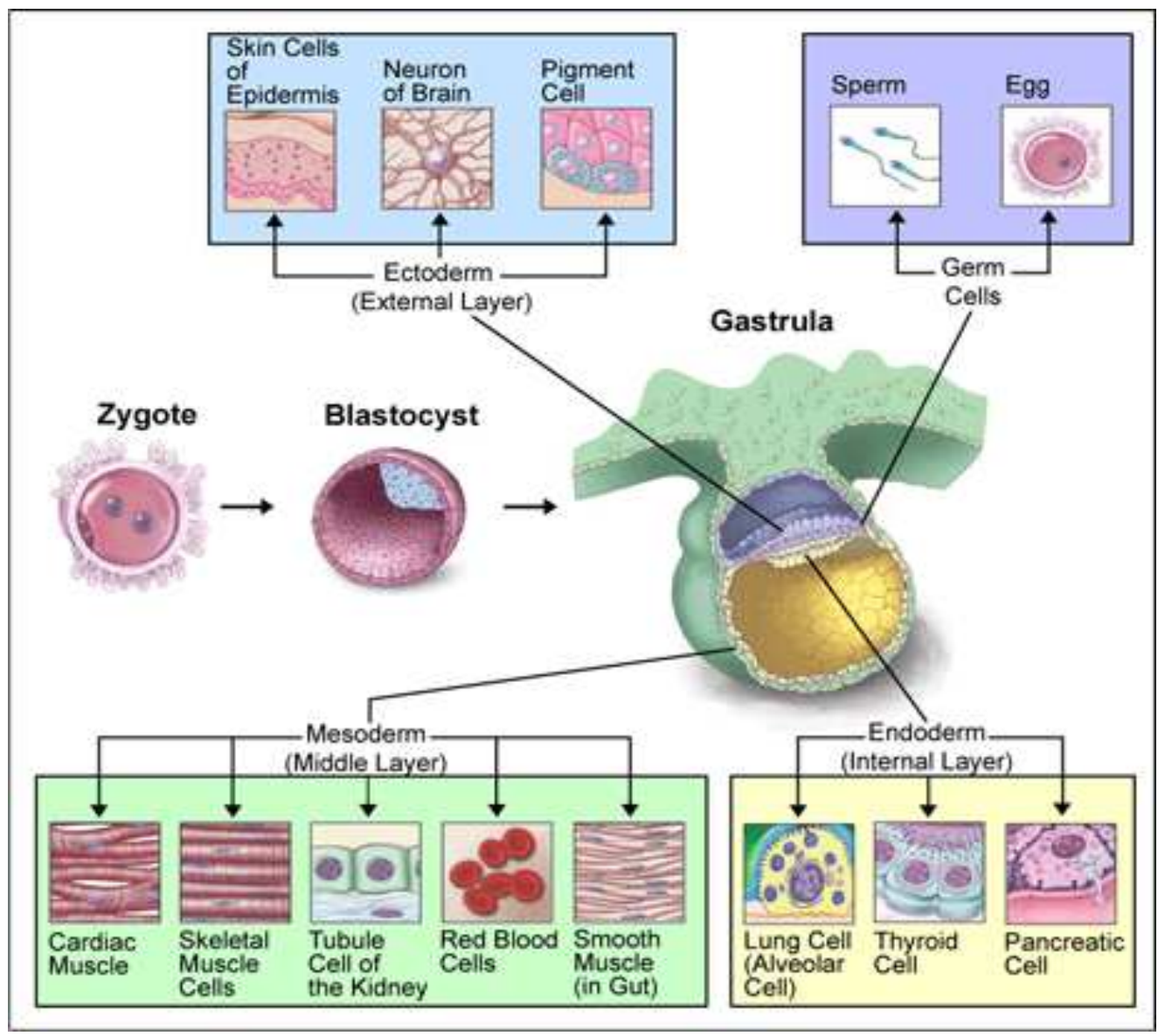

Representação esquemática do desenvolvimento embrionário demonstrando a formação dos três folhetos: endoderma, mesoderma e ectoderma e das células germinativas.

Fonte: Wikimedia Commons, 2009.

\subsection{Células Tronco Adultas}

As CTA constituem uma população de células multipotentes, que ao contrário do que se acreditava inicialmente, não estão envolvidas apenas no processo de reparação e homeostase dos tecidos dos quais são isoladas, mas também possuem diversos efeitos parácrinos que contribuem para a recuperação e regeneração de outros tipos celulares e tecidos do organismo. A capacidade das CTA de originar diversos tipos de células do indivíduo as têm tornado extremamente atrativas para a regeneração de tecidos (CAPLAN, 2000, 2003, 2005). Diferentemente das CTE as CTA não fazem uso de embriões como material biológico, contornando assim as questões éticas, culturais e religiosas envolvidas. Além disso, o avanço tecnológico tem ajudado a visualizar o real potencial da utilização terapêutica das CTA, e a sua capacidade de regeneração de tecidos danificados está sendo 
amplamente estudada em modelos animais (MONTEIRO et al., 2009; PITTENGER; MARTIN, 2004; TOHMA et al., 2008).

Há uma controvérsia na literatura a respeito do potencial de diferenciação de CTA. Alguns autores acreditam que as células originadas de um determinado folheto embrionário não possuem a capacidade de se diferenciar em células originadas de outro folheto. Assim, muitos autores não reconhecem as CTM como uma possível fonte de reposição neuronal devido ao fato destas células terem origem mesodermal e não ectodermal, como a linhagem neurogênica. Até o momento, muitas evidências são descritas sobre o comportamento das CTM, sugerindo que em condições apropriadas, estas podem se diferenciar, não somente na linhagem mesodermal, mas também nas linhagens endodermal e ectodermal in vitro, e que portanto, apresentam sim a capacidade de diferenciação em neurônios (HERZOG et al., 2003).

\subsection{Células Tronco Imaturas da Polpa Dentária}

Ainda que células tronco provenientes de diferentes fontes possuam propriedades similares, o seu potencial terapêutico e de desenvolvimento são devidos à sua origem embrionária. Sabe-se que a polpa dentária é derivada a partir da crista neural, uma estrutura embrionária transitória, que se origina após a migração das células tronco da crista neural (CTCN). Estas constituem uma população de células pluripotentes e migratórias, que exibem um potencial de desenvolvimento similar ao de CTE. CTCN são capazes de se diferenciar em um amplo espectro de tipos celulares durante o desenvolvimento, como células da glia, neurônios, células da retina, ossos, tendões, melanócitos, condrócitos, células endócrinas, células adiposas entre outras (SIQUEIRA DA FONSECA et al., 2009; SIQUEIRA et al., 2011). Embora a pluripotência das CTCN se torne mais restrita durante o desenvolvimento, a sua célula homóloga pós-natal mantém a capacidade de autorrenovação (TAKAHASHI et al., 1998). Uma vez que apenas um número limitado de CTCN pode ser isolado do embrião, uma alternativa seria a utilização de culturas de células tronco com capacidade de expansão e manutenção in vitro e que apresentem características semelhantes às das CTCN. O padrão de expressão de marcadores específicos para origem embrionária, clonogenicidade, capacidade de proliferação e autorrenovação observado em células tronco da polpa dentária (CTPD) sugerem sua equivalência a CTCN.

$\mathrm{Na}$ tentativa de estudar células tronco sem risco de formação tumoral e com potencial de diferenciação em células retinianas, um tipo peculiar de células tem sido nosso foco de 
estudo. Trata-se das células tronco imaturas da polpa dentária (CTIPD) (KERKIS et al., 2006). A originalidade do nosso trabalho com este tipo celular está no fato de utilizarmos condições de cultivo para as CTIPD semelhantes às descritas para CTE. O método de obtenção destas células evita o uso de qualquer tipo de digestão enzimática da polpa dentária e dessa forma obtemos a partir de polpa dentária humana, células multipotentes correspondentes a um tipo celular intermediário entre CTE e CTA (JIANG et al., 2002). Pela primeira vez demonstramos também que as células isoladas de polpa dentária, além de expressar estavelmente os marcadores de CT mesenquimais (SH3, SH4, CD90 e CD105) durante as passagens contínuas, expressam também no seu estado indiferenciado, um grupo de antígenos estágio-específicos de superfície celular (SSEA-3, SSEA-4) e fatores de transcrição específicos de CTE (TRA-1-60, TRA-1-81, Oct-4 e Nanog) (LASLETT; FILIPCZYK; PERA, 2003), demonstrando assim, que nossas células apresentam o perfil de expressão semelhante àquele observado nas CTE humanas (KERKIS et al., 2006). Além disso, as CTIPD são facilmente isoladas e através de um método não invasivo, o que não implica em problemas de segurança biológica. Foi comprovado ainda, por ensaios de injeção das CTIPD em camundongos imunossuprimidos e imunocompetentes, que estas não são capazes de formar tumores e não provocam processos de rejeição imunológica.

Estudos in vivo mostraram significativo potencial das CTIPD para o tratamento da distrofia muscular em modelo canino com a integração das CTIPD humanas ao músculo do receptor animal e a produção de distrofina (KERKIS et al., 2008). Estas células também se mostraram eficazes no tratamento de defeitos ósseos cranianos em modelo murino, com integração morfológica (MENDONÇA COSTA et al., 2008). A melhora funcional também foi observada em outro estudo com CTIPD num modelo de lesão de medula espinhal em camundongos (ALMEIDA et al., 2011). É importante frisar que não foi necessário nenhum protocolo de imunossupressão em quaisquer dos estudos anteriores.

Nosso grupo também estudou o efeito das CTIPD em um modelo de deficiência límbica (queimadura química da córnea) em coelhos. Após remoção cirúrgica do tecido fibrovascular resultante da queimadura, foram transplantadas CTIPD humanas na superfície ocular destes animais. Posteriormente, com tempos diferentes de análise, observamos significativa melhora da transparência da córnea em comparação com o controle, assim como expressão positiva de marcadores específicos de células tronco do limbo (MONTEIRO et al., 2009; GOMES et al., 2010). O nosso grupo está realizando em colaboração com o CASO UNIFESP (Centro Avançado de Superfície Ocular - Universidade Federal Paulista) um ensaio 
clínico fase I para o tratamento de seres humanos com lesões na córnea com uso das CTIPD, sob autorização do CONEP (Comissão Nacional de Ética em Pesquisa).

\subsection{Terapia Celular e Retina}

Recentes avanços na pesquisa com células tronco têm voltado sua atenção na aplicação da terapia celular para regenerar tecidos oculares danificados por uma doença degenerativa ou injúria. Diferentes situações clínicas determinam que as abordagens terapêuticas sejam distintas em cada caso, por exemplo, quando a maioria ou todos os fotorreceptores foram perdidos ou não funcionam ou quando algumas células fotorreceptoras ainda estão funcionando. $\mathrm{Na}$ ausência de fotorreceptores funcionantes, são mais fundamentadas estratégias de tratamentos que substituam as células fotorreceptoras ou substituam a função da retina, como terapia celular e próteses de visão artificial. A reposição de fotorreceptores tem sido estudada utilizando-se transplante de fotorreceptores ou por terapias celulares com células tronco ou células progenitoras.

Muitos estudos apontam como potencial alternativa para reposição de neurônios danificados a utilização das CT, o que tornaria possível a restauração da rede de neurônios retinais, visando recuperar o poder de conexão entre estes e o nervo ótico. Em 2008, pesquisadores realizaram transplantes de CT de medula óssea de rato, tanto indiferenciada (GONG et al., 2008) como pré-diferenciada para neurônios-like (XUFANG et al., 2007), no espaço vítreo de animais da mesma espécie, demonstrando o potencial destas células, porém tais trabalhos não comprovaram a funcionalidade do tecido recuperado, limitando-se a dados histológicos e imunohistoquímicos. As CTE também tem sido diferenciadas em progenitores retinais e injetadas em camundongos, podendo ser úteis em tratamentos de doenças degenerativas da retina (LAMBA et al., 2006). Porém, estas células envolvem questões éticas e de segurança biológica como a possibilidade de desenvolvimento tumoral e reações de histocompatibilidade, o que inviabiliza a aplicação clínica das mesmas.

Durante o desenvolvimento embrionário, o epitélio retiniano dos vertebrados, contém células conhecidas como progenitoras retinianas e ao contrário de hipóteses prévias, foi demonstrado que as células progenitoras do sistema nervoso central permanecem multipotentes durante o desenvolvimento (KLASSEN; SAKAGUCHI; YOUNG, 2004). Por exemplo, células progenitoras retinianas de recém-nascidos apresentam capacidade de diferenciação mais restrita do que aquelas no estágio embrionário. Mesmo assim, estas células são capazes de gerar alguns tipos de neurônios e também células gliais de Müller. Acredita-se 
que essa ação mais restrita após o nascimento esteja relacionada a vários fatores intrínsecos e extrínsecos do ambiente retiniano (KLASSEN, 2004). As células progenitoras retinianas são proliferamente ativas e dão origem a uma progênie que se diferencia em várias linhagens celulares da retina. Desta maneira, as células do EPR também tem sido estudadas por serem capazes de dar origem a diferentes tipos de neurônios (DAS et al., 2005), mas por provirem de outro organismo, acarretam problemas de rejeição imunológica.

A mais significante contribuição na pesquisa de células tronco em retina foi dada com o trabalho de MacLaren et al. (2006), onde foram testadas células progenitoras retinianas extraídas da retina de embriões de camundongos, células precursoras de bastonetes de camundongos recém-nascidos (1 a 7 dias de vida) e células retinianas de camundongos adultos. As células precursoras de bastonetes, que expressam o gene $\mathrm{Nrl}$, incorporaram-se à retina de camundongos sadios e com três tipos diferentes de degeneração retiniana e estabeleceram conexões sinápticas com as células bipolares após injeção subretiniana. Além disso, expressaram marcadores de bastonetes maduros. Nos testes de avaliação funcional, todos os parâmetros estavam melhorados em comparação com o grupo não tratado, mesmo quando injetadas na retina já em degeneração. Desde então, outros estudos já mostraram a real transformação de células tronco em fotorreceptores funcionais. Mais precisamente, três estudos relevantes mostraram que células tronco pluripotentes induzidas (do inglês, iPS) foram pré-diferenciadas in vitro e injetadas no espaço subretiniano de camundongos e porcos. Em ambos os trabalhos, houve integração de células que expressavam marcadores de fotorreceptores e melhora da função visual. No entanto, o maior risco encontrado foi a formação tumoral. Sabe-se que células iPS apresentam este risco aumentado e isso foi constatado em um pequeno percentual dos casos mesmo após diferentes tentativas de eliminação das células que expressavam marcadores oncogênicos (LAMBA et al., 2010; TUCKER et al., 2011; ZHOU et al., 2011).

Idealmente estuda-se a reposição das células da retina, porém este efeito terapêutico é mais difícil de ser alcançado principalmente devido a grande diferenciação e especificidade funcional dos fotorreceptores. Desta maneira, outro efeito terapêutico que tem sido bastante analisado é o efeito parácrino, isto é, a possibilidade das células implantadas melhorarem as condições do microambiente tecidual para que a célula fotorreceptora possa sobreviver e funcionar melhor. O processo de reparação tecidual é fisiológico. Mediadores químicos são liberados para recrutar células inflamatórias que compõe o tecido cicatricial e novos vasos. A expressão celular muda em função de modificações do ambiente. A modulação destes mediadores poderá ser chave para a longevidade celular. 
Outra questão de relevância para o sucesso do transplante de células tronco na retina é o local da injeção destas células. As vias mais comumente utilizadas são a intravítrea e a subretiniana. Embora muitos trabalhos utilizem injeções intravítreas (DORRELL et al., 2004; JONAS et al., 2010), já foi demonstrado que a porcentagem de células capazes de migrar para a retina neural após injeção subretiniana é bem maior (MACLAREN et al., 2006). No trabalho publicado por Sakaguchi et al., (2004) nem sequer houve integração das células transplantadas na retina neural hospedeira após injeção intravítrea. A injeção sistêmica de células tronco de medula óssea para prevenir a degeneração dos fotorreceptores também já foi avaliada em humanos, porém nenhuma melhora da função visual foi constatada (WANG et al., 2010).

\subsection{Células Tronco Imaturas de Polpa Dentária e Retina}

Como já previamente descrito neste trabalho, as CTIPD surgiram como uma fonte promissora de células tronco que podem ser utilizadas na clínica, e uma vez que o tecido pulpar tem origem mista, sendo formado pela junção de células do mesênquima e da crista neural, estas células se mostram extremamente atrativas para a restauração retiniana. Um fato que corrobora com essa possível aplicação é a expressão de nestina (proteína ectodermal) e vimentina (proteína mesenquimal) nas células tronco da polpa dentária (MOSCOVICI, 2009). Kerkis et al. (2006) demonstraram que as CTIPD foram capazes de abandonar sua herança mesenquimal e adquirirem características morfológicas e imunocitoquímicas de neurônios e células da glia em cultura. As características imunocitoquímicas foram determinadas pela expressão de proteínas como beta-tubulina e GFAP.

Sendo a retina neural constituída por células da mesma origem ectodermal que as CTIPD, estas células podem trazer uma 'memória' embrionária e portanto dar origem não somente a neurônios do sistema nervoso central (SNC), mas a neurônios retinais-símile também, o que possibilitaria um grande avanço na tentativa de estabelecer um tratamento efetivo na recuperação da visão. Ressalta-se ainda que esta seria uma nova terapia superior às terapias convencionais, que atualmente são apenas paliativas. 
3 OBJETIVOS 


\subsection{Objetivo Geral}

O presente projeto tem por objetivo: avaliar o potencial de diferenciação, in vitro, das CTIPD em neurônios retinais, visando uma futura aplicação terapêutica em doenças degenerativas da retina.

\subsection{Objetivos Específicos}

- Estabelecer um protocolo efetivo para a formação de neuroesferas;

- avaliar diferentes protocolos para a diferenciação das neuroesferas formadas em neurônios retinais;

- analisar por imunofluorescência, o potencial de diferenciação das CTIPD em neurônios retinais. 
4 MATERIAIS E MÉTODOS 


\subsection{Células Tronco Imaturas da Polpa Dentária}

Para este estudo foi utilizada apenas uma linhagem de CTIPD, denominada DL5 (dente de leite 5), a qual foi previamente estabelecida e caracterizada pela $\operatorname{Prof}^{\mathrm{a}} \operatorname{Dr}^{\mathrm{a}}$ Irina Kerkis, no Laboratório de Genética do Instituto Butantan, São Paulo, SP (LIZIER et al., 2012). As CTIPD foram extraídas de dentes decíduos esfoliados de uma criança com 7 anos de idade, após consentimento informado dos responsáveis pelo paciente. Brevemente, o tecido pulpar proveniente dos dentes foi colocado em placas de Petri $35 \mathrm{~mm}\left(\mathrm{Nunc}^{\mathrm{TM}}\right)$, em meio de cultivo basal constituído por $15 \%$ soro fetal bovino (SFB - HyClone, Logan, UT - USA) e DMEM-F12 (Dulbecco's Modified Eagles Médium - Gibco, Grand Island, NY - USA), suplementado com $1 \%$ penicilina e streptomicina (Gibco), 1\% L-glutamina $200 \mathrm{mM}$ (Gibco) e $1 \%$ aminoácidos não essenciais (ANE - Gibco). $\mathrm{O}$ tecido foi mantido em estufa para cultivo celular à temperatura de $37^{\circ} \mathrm{C}$ e $5 \%$ de $\mathrm{CO}_{2}$ até que as células tronco começassem a migrar do tecido pulpar para a superfície plástica da placa. Após sete dias, as células foram dissociadas enzimaticamente (TrypLE Express 0,25\% - Gibco), sendo uma parte replaqueada e outra parte criopreservada.

\subsection{Cultivo e Expansão das CTIPD}

As CTIPD - DL5, na passagem quatro, foram descongeladas em banho-maria a $37{ }^{\circ} \mathrm{C}$ por 2 minutos. Em seguida, as células foram lavadas com meio de cultivo basal e foram então plaqueadas em garrafas de cultura de $25 \mathrm{~cm}^{2}$. O meio de cultivo utilizado foi o mesmo descrito para o isolamento das CTIPD (KERKIS et al., 2006). Após atingirem semiconfluência (aproximadamente 70\%), as células foram submetidas a uma dissociação enzimática, para que uma parte pudesse ser novamente criopreservada, enquanto a outra parte das células eram replaqueadas em novas garrafas de cultivo a fim de expandi-las, bem como realizar as análises descritas a seguir.

\subsection{Cultivo e Expansão das Células do Epitélio Pigmentar da Retina (EPR)}

As células do EPR (linhagem ARPE-19) de origem humana foram cedidas pelo Dr. Gustavo Grottone do Departamento de Oftalmologia da Escola Paulista de Medicina UNIFESP, o qual é colaborador deste projeto. Brevemente, as células foram cultivadas em meio DMEM-F12 (Gibco), 10\% SFB comum (LGC, São Paulo, Brasil), 1\% ANE (Gibco), 
1\% L-glutamina 200 mM (Gibco) e 1\% antibiótico (Gibco). Ao atingirem confluência de $100 \%$, ocupando toda a placa de cultivo de $35 \mathrm{~mm}$, as células foram desagregadas por tripsina $0,25 \%$ (Invitrogen) e expandidas para posteriormente serem utilizadas nos testes de diferenciação das neuroesferas em neurônios retinais. O meio de cultura utilizado na expansão das células do EPR (meio condicionado) foi armazenado e usado como método alternativo na tentativa de diferenciação retinal.

\subsection{Caracterização}

\subsubsection{Imunofluorescência}

No intuito de analisar a expressão de alguns marcadores da diferenciação retinal (APÊNDICE - quadro 1) nas CTIPD, bem como avaliar a diferenciação das neuroesferas (APÊNDICE - quadro 2), realizamos a técnica de imunofluorescência. Os anticorpos secundários utilizados estão descritos no quadro 3 do apêndice. Brevemente, as células foram lavadas duas vezes com solução de lavagem tamponada (PBS - do inglês, phosphate-buffered saline) e então fixadas com paraformaldeído $4 \%$ durante pelo menos 12 horas. No dia seguinte, elas foram lavadas duas vezes em tampão de lavagem + Tween 20 (TBS - 20 mM Tris- $\mathrm{HCl}, \mathrm{pH} 7,4 ; 0,15 \mathrm{M} \mathrm{NaCl} ; 0,05 \%$ Tween-20) e permeabilizadas com $0,1 \%$ Triton (Sigma, St Louis, MO, USA). Em seguida, as células foram bloqueadas com albumina bovina a 5\% (BSA - Sigma), e então incubadas com os respectivos anticorpos primários por uma hora à temperatura ambiente. Após lavar três vezes com TBS, os anticorpos secundários foram adicionados por uma hora. As diluições de todos os anticorpos estão descritas nos quadros do apêndice. As lâminas foram então preparadas em meio de montagem Vectashield com 4‘,6-Diamidino-2-phenylindol (DAPI - Vector Laboratories, Burlingame, CA - USA) e analisadas por microscopia de fluorescência (Nikon Eclipse Ti - Tóquio, Japão).

\subsubsection{Citometria de Fluxo}

Com o mesmo intuito de avaliar a expressão dos marcadores específicos para células retinais, citados anteriormente (APÊNDICE - quadro 1), utilizamos a técnica de citometria de fluxo. As CTIPD indiferenciadas foram cultivadas em garrafas de cultura de $75 \mathrm{~cm}^{2}$ (Corning, NY, USA) até atingirem $70 \%$ de confluência. Neste ponto, estas foram digeridas enzimaticamente (TrypLE Express, Gibco), contadas com o auxílio da câmara de Neubauer, e 
transferidas na concentração $5 \times 10^{5}$ células para tubos específicos para citometria de fluxo. Após a centrifugação a $1000 \mathrm{rpm}$ por cinco minutos, o sobrenadante foi descartado e as células foram ressuspendidas em PBS contendo $2 \%$ soro fetal bovino e o anticorpo de interesse. As células foram então incubadas por 1 hora a $4{ }^{\circ} \mathrm{C}$. Em seguida, as células foram novamente centrifugadas e ressuspendidas em $1 \mathrm{ml}$ de PBS para serem analisadas em um FACS (fluoeresce-activated cell sorter, Becton Dickinson, São Jose, CA), usando o programa CELL Quest (Becton Dickinson).

\subsection{Diferenciação das CTIPD em Neuroesferas}

As CTIPD foram cultivadas em garrafa de cultivo de $25 \mathrm{~cm}^{2}$ até atingirem a semiconfluência de $70 \%$. Em seguida, as células foram tripsinizadas e divididas em duas placas de $35 \mathrm{~mm}$, previamente tratadas com agarose 1\% (Sigma), a qual formava uma fina camada sobre o fundo da placa. O meio de diferenciação utilizado foi Neurobasal suplementado com 3\% B27 (ambos da Gibco). As placas foram incubadas à temperatura de $37{ }^{\circ} \mathrm{C}$ e $5 \%$ de $\mathrm{CO}_{2}$ e mantidas por 3 dias na estufa. No segundo dia, já foi possível observar o início da formação de estruturas esféricas em suspensão.

\subsection{Transferência das Neuroesferas}

Uma vez formadas as neuroesferas em suspensão, fez-se necessária a transferência dessas estruturas para outra placa de cultivo, bem como o uso de lamínulas e soro para adesão. Desta maneira, adaptamos uma técnica para aspiração das neuroesferas, utilizando-se de um microscópio invertido (Nikon Eclipse TE200) e uma micropipeta de volume $10 \mu 1$ (Eppendorf, Hamburgo, Alemanha). As esferas foram aspiradas uma a uma, evitando ao máximo a sucção do meio e sem atingir a camada de agarose, sendo então transferidas para nova placa de $35 \mathrm{~mm}$, contendo lamínula e meio basal de cultivo das CTIPD, o qual continha soro fetal bovino. Foram mantidas nestas condições por mais quatro dias. Dentro deste período houve apenas uma troca do meio.

\subsection{Microscopia Eletrônica de Transmissão}

As neuroesferas produzidas, segundo nosso protocolo, descrito na seção 4.5 desta dissertação, foram coletadas em tubo falcon contendo solução de glutaraldeído 2,5\% para 
fixação. Em seguida, as células foram lavadas com solução de PBS duas vezes para uma nova fixação, agora com ósmio (Polysciences, Inc., USA) a $1 \%$ a $4{ }^{\circ} \mathrm{C}$ durante uma hora. Após este período, as células foram submetidas à desidratação em série crescente de alcoóis $(50 \%, 70 \%$, 95\% e 100\%) e a amostra passou então por cinco banhos antes do processo de inclusão, sendo eles:

- óxido de propileno por duas vezes de 10 minutos cada;

- óxido de propileno, acrescido de resina araldite na proporção 3:1 por duas horas;

- óxido de propileno, acrescido de resina araldite na proporção 1:1 por duas horas;

- óxido de propileno, acrescido de resina araldite na proporção 1:3 por duas horas;

- resina araldite pura durante 5 horas.

Após os banhos, as esferas foram incluídas em resina araldite e incubadas em estufa a $60{ }^{\circ} \mathrm{C}$ por 72 horas para polimerização da resina.

O material foi processado em ultramicrótomo Reichert-Jung, modelo Ultracut com cortes de $400 \mathrm{~nm}$ de espessura. Para a visualização foi realizada uma coloração de contraste com uranil acetato $1 \%$ por 5 minutos e nitrato de chumbo por mais 5 minutos. As amostras foram então analisadas em microscópio eletrônico de transmissão LEO-806E.

\subsection{Diferenciação das Neuroesferas em Progenitores Retinais}

A fim de induzir as neuroesferas a adquirirem características de progenitores retinais, coletamos algumas esferas, após quatro dias de sua formação na placa de agarose, para transferi-las para nova placa de $35 \mathrm{~mm}$ com lamínula. Porém desta vez, o meio não foi substituído para um meio de cultivo contendo soro, e sim mantido o mesmo meio de diferenciação (Neurobasal e B27) acrescido apenas de um conhecido indutor da diferenciação retinal/neural, o ácido retinóico (AR - Sigma), na concentração final de 0,5 $\mu \mathrm{M}$. As esferas foram mantidas nestas condições por mais quatro dias e foram então fixadas com formaldeído $4 \%$ para posterior análise.

\subsection{Co-cultivo das Neuroesferas com Células do EPR}

Após a confirmação e determinação do melhor protocolo para diferenciação das CTIPD em neuroesferas, estas foram co-cultivadas com as células do EPR no período de cinco a dez dias. Para bloquear a proliferação das células do EPR, estas foram pré-tratadas com mitomicina C (Concentração $10 \mathrm{ug} / \mathrm{ml}$ ) por 3 horas e então lavadas três vezes com 
solução de PBS. As neuroesferas foram selecionadas de acordo com tamanho e formato mais próximos do ideal e transferidas manualmente, uma a uma, para a placa contendo o EPR, o qual atuou como camada de alimentação (“feeder monolayer”).

\subsection{Desagregação das Neuroesferas}

Como método alternativo para a diferenciação retinal, utilizamos uma técnica que consiste em desagregar as neuroesferas e plaqueá-las em diferentes meios de cultivo para obtenção do melhor método de diferenciação. As neuroesferas foram coletadas em microtubos de 1,5 ml, centrifugadas a 1000 RPM por 5 minutos, lavadas com PBS e incubadas por 10 minutos em solução de tripsina 0,25\%. Em seguida, as esferas já desagregadas foram semeadas em placas de 12 poços para avaliação, em duplicata, de seis tipos diferentes de meios, divididos em três grupos descritos a seguir. A divisão foi realizada de acordo com o meio basal utilizado, diferindo apenas pelos agentes indutores.

\section{GRUPO 1}

-Meio 1: Neurobasal + B27 + Ácido retinóico

-Meio 2: Neurobasal + B27 + Ácido retinóico + FGF (Fibroblast Grown Factor)

\section{GRUPO 2}

-Meio 3: 50\% Meio condicionado EPR + 50\% Neurobasal + B27 + Ácido retinóico -Meio 4: 50\% Meio condicionado EPR + 50\% Neurobasal + B27 + Ácido ret. + FGF

\section{GRUPO 3}

-Meio 5: Meio condicionado EPR sem indutores

-Meio 6: Meio condicionado EPR + B27 + Ácido retinóico + FGF

\subsection{Diferenciação das CTIPD em Neurônios Retinais}

Para avaliarmos se seria possível realizar a diferenciação retinal sem a passagem pelo estágio de neuroesfera, iniciamos o protocolo de diferenciação diretamente da cultura de CTIPD. As células foram cultivadas sob condições padrão, com meio basal em garrafa de 25 $\mathrm{cm}^{2}$ até atingirem uma confluência de aproximadamente $90 \%$. Foram então digeridas enzimaticamente e plaqueadas em uma placa de 6 poços contendo lamínula de vidro e meio 
neurobasal, acrescido de 2\% B27 e 0,5 uM de ácido retinóico. A cultura foi mantida por 21 dias, sendo o meio trocado a cada sete dias. A fixação das células foi realizada com formaldeído $4 \%$.

\subsection{Diferenciação das Neuroesferas em Neurônios Retinais}

Para tal teste de diferenciação, utilizamos nosso próprio protocolo de diferenciação das CTIPD em neuroesferas e sua posterior transferência para adesão à placa de cultivo, como descrito, respectivamente, nas seções 4.5 e 4.6 desta dissertação. As esferas aderidas foram então mantidas em cultura por cinco dias, em meio Neurobasal acrescido de $2 \%$ de B27 e 0,5 uM de ácido retinóico, até o momento que as células começaram migrar da esfera. Foi realizada uma digestão enzimática, utilizando tripsina $0,25 \%$, e as células foram replaqueadas em nova placa de petri de $35 \mathrm{~mm}$, mantendo o mesmo meio de cultivo por mais 10 dias, porém com acréscimo de $5 \mathrm{uM}$ de Ácido retinóico, sendo o meio trocado a cada 3 dias. A cultura foi mantida por mais cinco dias, quando foi fixada em formaldeído $4 \%$.

$\mathrm{Na}$ repetição do experimento, modificamos a quantidade de células a serem submetidas à formação das neuroesferas, plaqueando menos células que no experimento inicial. O protocolo seguido foi o mesmo sem alteração no tempo ou meio de cultivo utilizados. 
Figura 8 - Etapas da Diferenciação das CTIPD em Neurônios Retinais-símile

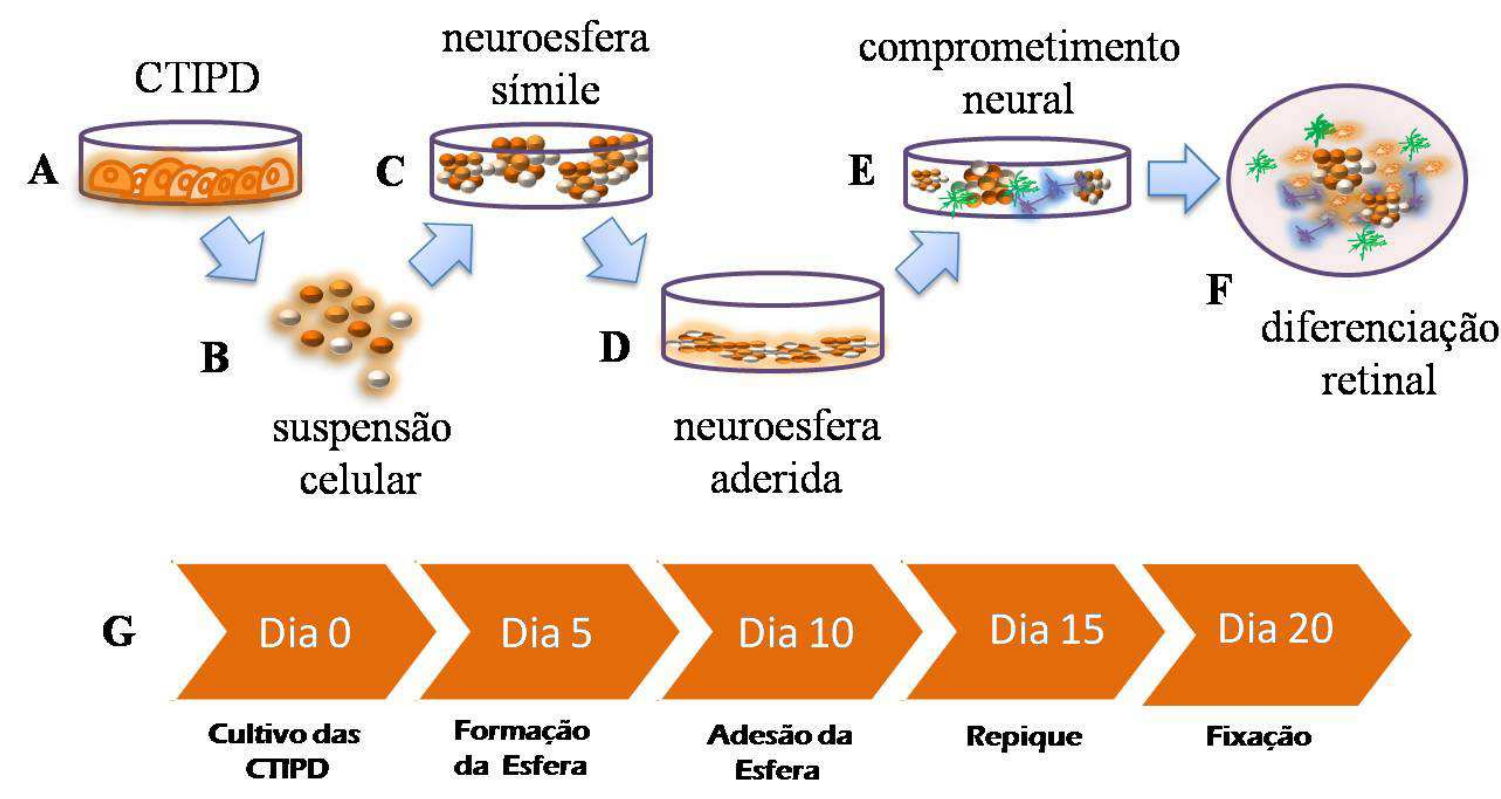

A) CTIPD indiferenciadas em meio basal. B) Suspensão das CTIPD. C) Formação dos agregados celulares semelhantes as neuroesferas em meio NB + B27. D) Adesão das neuroesferas em meio NB + B27 com AR. E) Após o repique celular podemos observar agrupamentos celulares com comprometimento neural e presença de células gliais. F) Visão superior da placa E; neurosferas compostas por diferentes tipos de precursores. Na periferia notam-se células neurais diferenciadas. G) Linha do tempo demonstrando as ações do processo de diferenciação retinal. Diferentes cores representam diferentes tipos celulares (marrom = astrócitos; verde = oligodendrocitos; azul $=$ tipos diversos de neurônios, incluindo os fotoreceptores). $\mathrm{NB}=$ neurobasal; $\mathrm{AR}=$ ácido retinóico.

\subsection{Imunofluorescência nas Neuroesferas Diferenciadas em Neurônios Retinais}

O protocolo para realização da imunofluorescência após o processo de diferenciação foi o mesmo realizado para as células indiferenciadas e está descrito na seção 4.4.1. 
5 RESULTADOS 


\subsection{Cultivo e Expansão das CTIPD}

As CTIPD foram descongeladas como previamente descrito por Kerkis et al. (2006) e mantidas em cultura com meio basal, em estado indiferenciado. Pudemos observar a manutenção da morfologia fibroblast-like, bem como a capacidade de proliferação ativa.

Figura 9 - CTIPD Indiferenciada
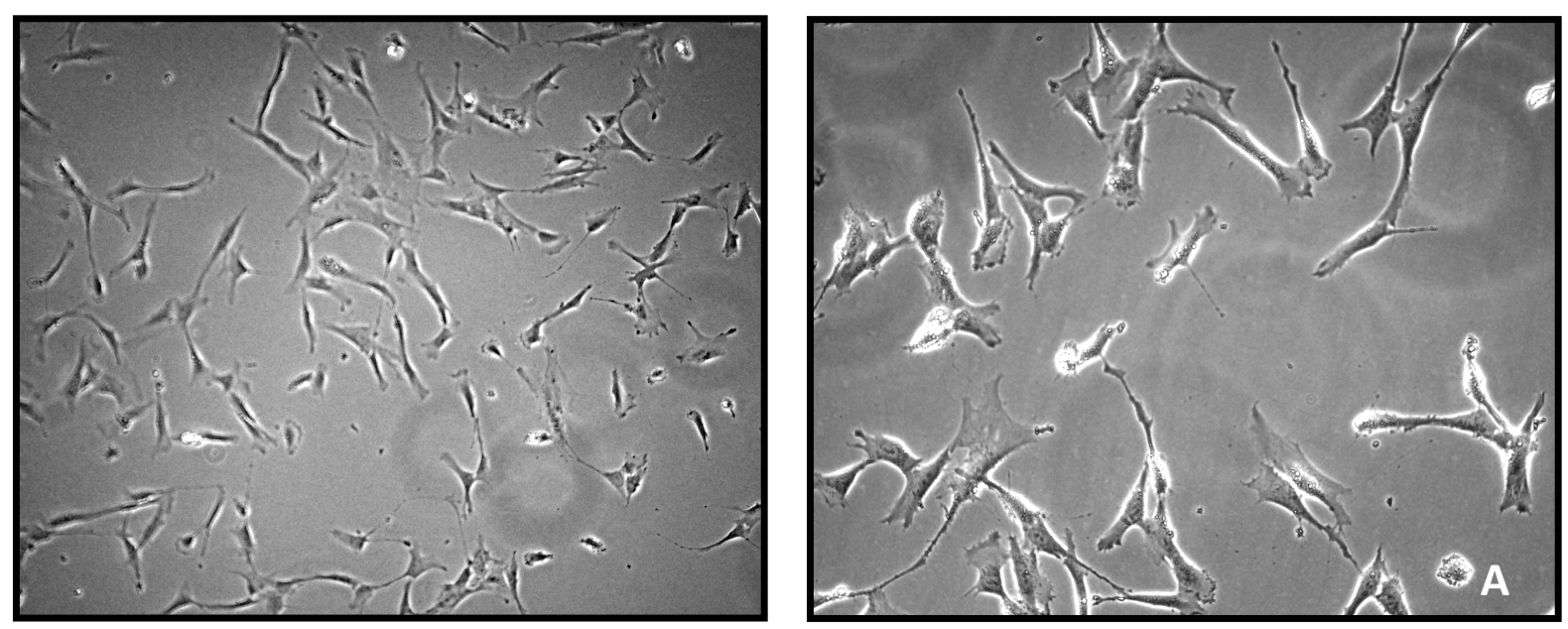

CTIPD indiferenciadas na passagem 4. A) objetiva 10x. B) objetiva 20x.

\subsection{Cultivo e Expansão das Células Epiteliais da Retina}

As células do EPR foram descongeladas em meio basal em garrafas de cultivo de 25 $\mathrm{cm}^{2}$. Após uma hora do procedimento, já podiam ser observadas células aderidas e com morfologia epitelial-like. Estas células foram tripsinizadas a cada três ou quatro semanas, uma vez que as mesmas eram mantidas em cultura mesmo depois de atingirem $100 \%$ de confluência. A cada repique, $50 \%$ do total de células eram divididos em até quatro garrafas de cultivo de $25 \mathrm{~cm}^{2}$ e os outros $50 \%$ eram novamente criopreservados. Quando as mesmas preenchiam completamente a superfície cultivável das garrafas (100\% de confluência) e eram mantidas em cultura por mais de três semanas, era possível observar a presença de pontos escuros no citoplasma das células, sugerindo a produção do pigmento típico desta cultura (melanina). 
Figura 10 - Células do Epitélio Pigmentar da Retina.
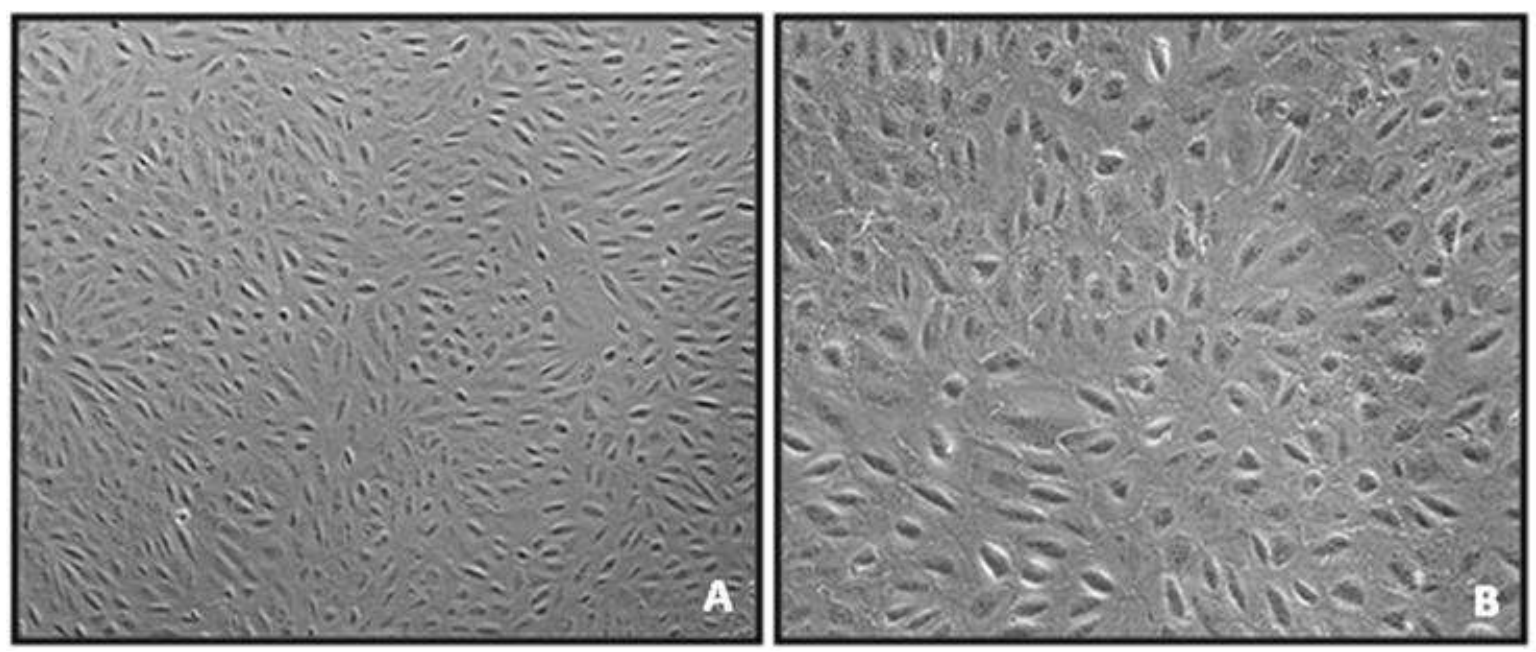

A - Células 100\% confluentes - objetiva 10x. B - Presença de pigmentos característicos dessas células - objetiva 20x.

\subsection{Caracterização das CTIPD}

\subsubsection{Imunofluorescência}

Avaliamos por imunofluorescência as CTIPD previamente caracterizadas pelo nosso grupo (LIZIER et al., 2012), com o intuito de verificar se estas células expressam CD73 (ecto5'-nucleotidase), um marcador de CTM que foi recentemente relatado ser um precursor retinal. Avaliamos também a expressão do marcador vimentina, uma proteína de filamento intermediário característica de células mesenquimais. Como pode ser observado na figura abaixo, ambos os marcadores foram positivos para as CTIPD na passagem 4 . 
Figura 11 - Imunofluorescência - CTIPD Indiferenciada
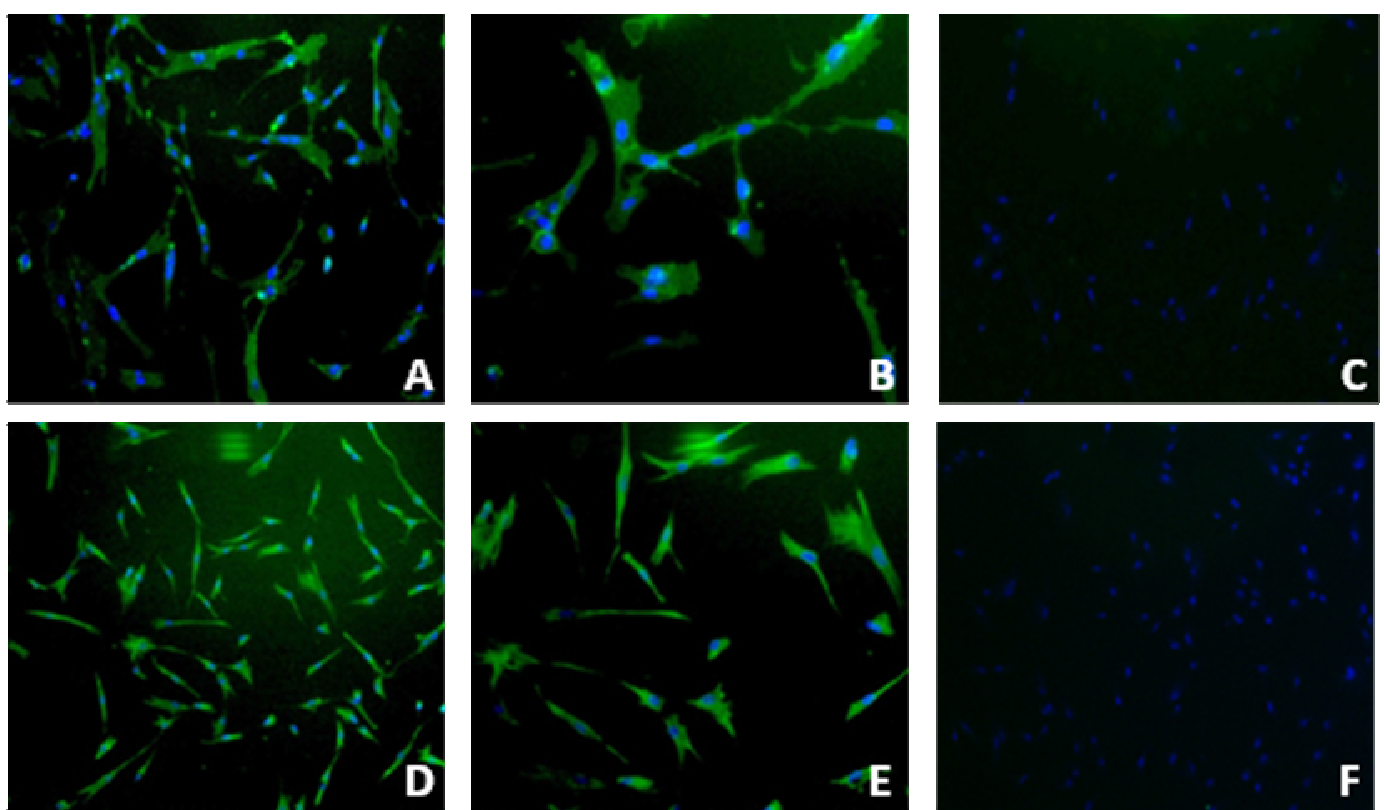

CTIPD indiferenciada mostrando marcação positiva para CD73 em A-10x e B-20x. Marcação positiva para Vimentina, como mostrado em D-10x e E-20x. C e F - Controles negativos (apenas anticorpo secundário) Núcleos foram corados com DAPI.

\subsubsection{Imunofluorescência - Marcadores Retinais}

Tendo em vista a origem embrionária das CTIPD na crista neural, a qual origina muitos dos tecidos cranianos, verificamos se as CTIPD, ainda indiferenciadas, expressavam ou não os marcadores específicos da diferenciação retinal, como Pax-6, Chx-10, Crx, Nrl, Calbindin e Rhodopsin. Demonstramos que as CTIPD foram negativas para estes anticorpos, comprovando que antes do início do processo de diferenciação, as CTPID indiferenciadas não expressam tais marcadores retinais. 
Figura 12 - Imunofluorescência - CTIPD Indiferenciada - Marcadores Retinais
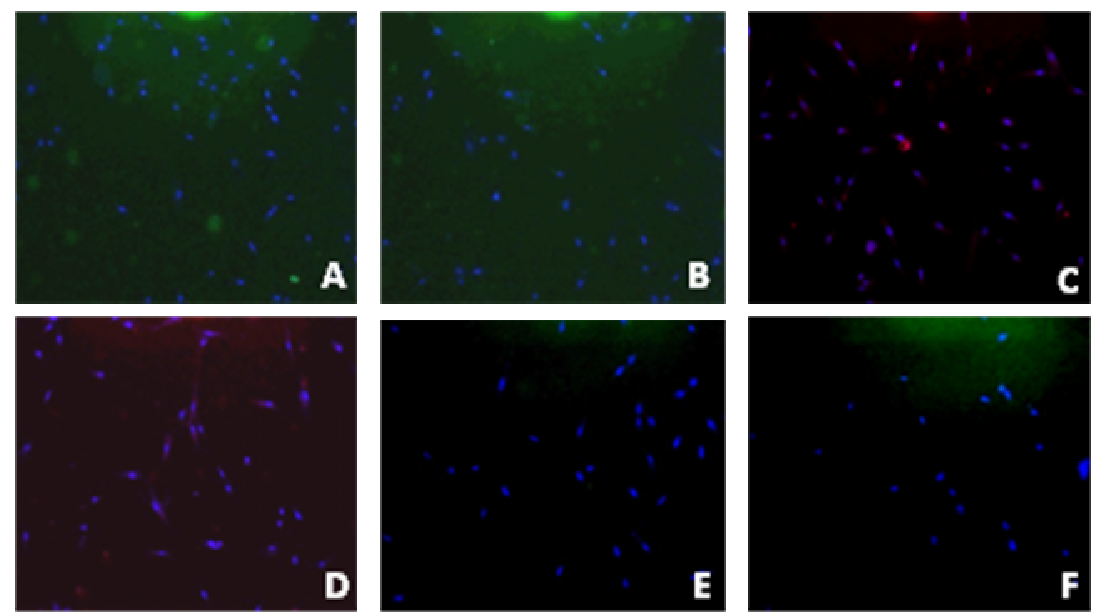

As CTIPD indiferenciadas não apresentaram marcação para todos os marcadores da diferenciação retinal. A-F) objetiva 10x. Núcleos corados com DAPI.

\subsubsection{Citometria de Fluxo (FACS)}

A fim de confirmar, por meio de outra técnica os resultados obtidos pela análise de imunofluorescência, realizamos uma avaliação por citometria de fluxo para os anticorpos específicos da diferenciação retinal (Pax-6, Chx-10, Crx, Nrl, Calbindin e Rhodopsin) e para o CD73. Os resultados com os marcadores retinais e para o CD73 foram os mesmos obtidos pela técnica de imunofluorescência, ou seja, não houve reação aos anticorpos avaliados para a diferenciação retinal, enquanto a expressão de CD73 foi confirmada. 
Figura 13 - Citometria de Fluxo - CTIPD Indiferenciadas
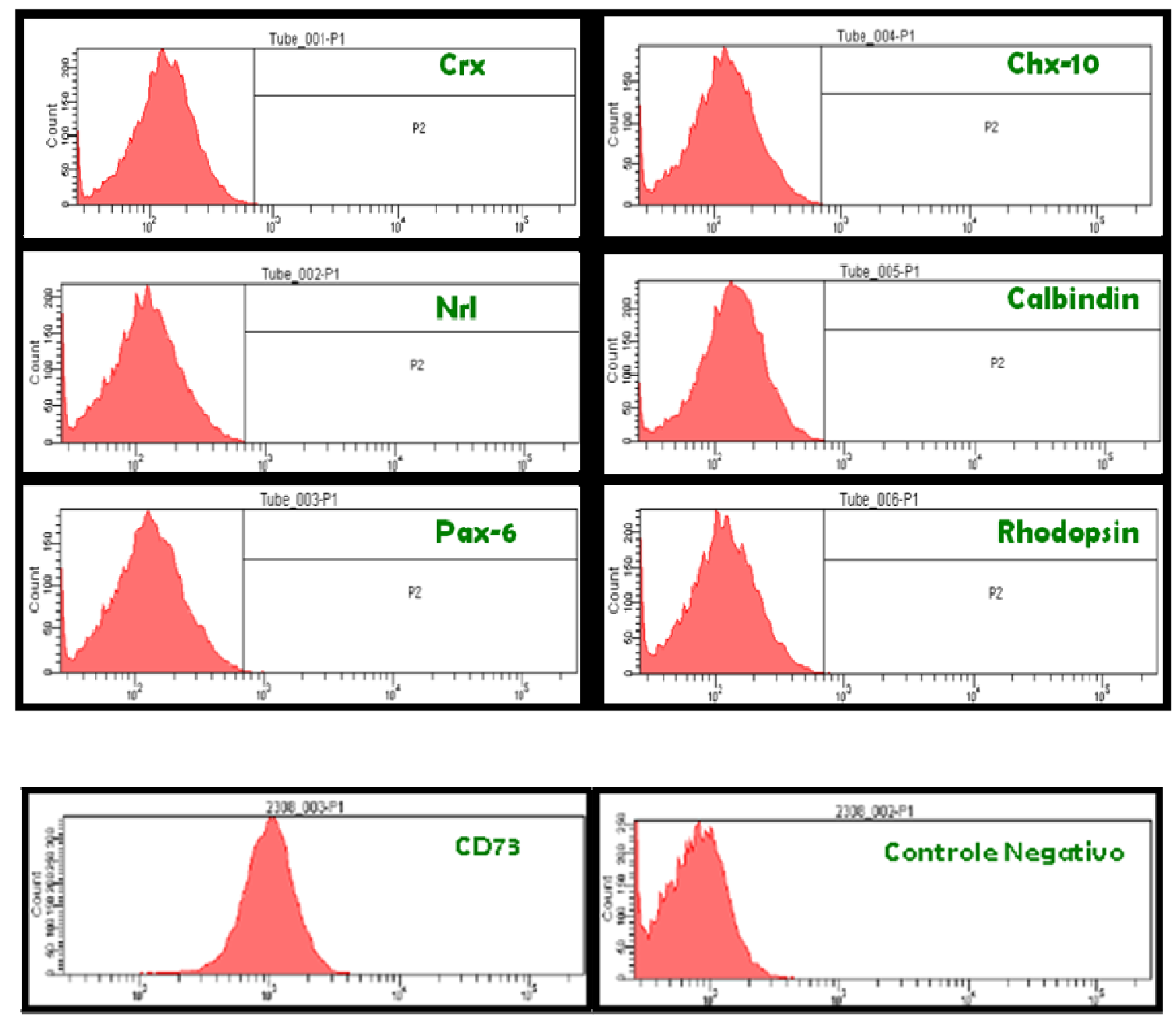

Histogramas individuais de citometria de fluxo demonstrando a curva deslocada para a esquerda no caso de expressão negativa (anticorpos específicos da diferenciação retinal e controle negativo) e a curva deslocada para a direita demonstrando marcação positiva para CD73. 


\subsection{Diferenciação das CTIPD}

\subsubsection{Neuroesferas}

Três dias após as CTIPD terem sido submetidas ao protocolo de diferenciação desenvolvido pelo nosso grupo, pudemos observar diversas estruturas semelhantes à neuroesferas formadas na placa, podendo ser notados diferentes tamanhos e formas. As esferas menores e disformes foram descartadas, sendo escolhidas para posterior análise, somente aquelas maiores e de formato regular.

Figura 14 - Neuroesferas
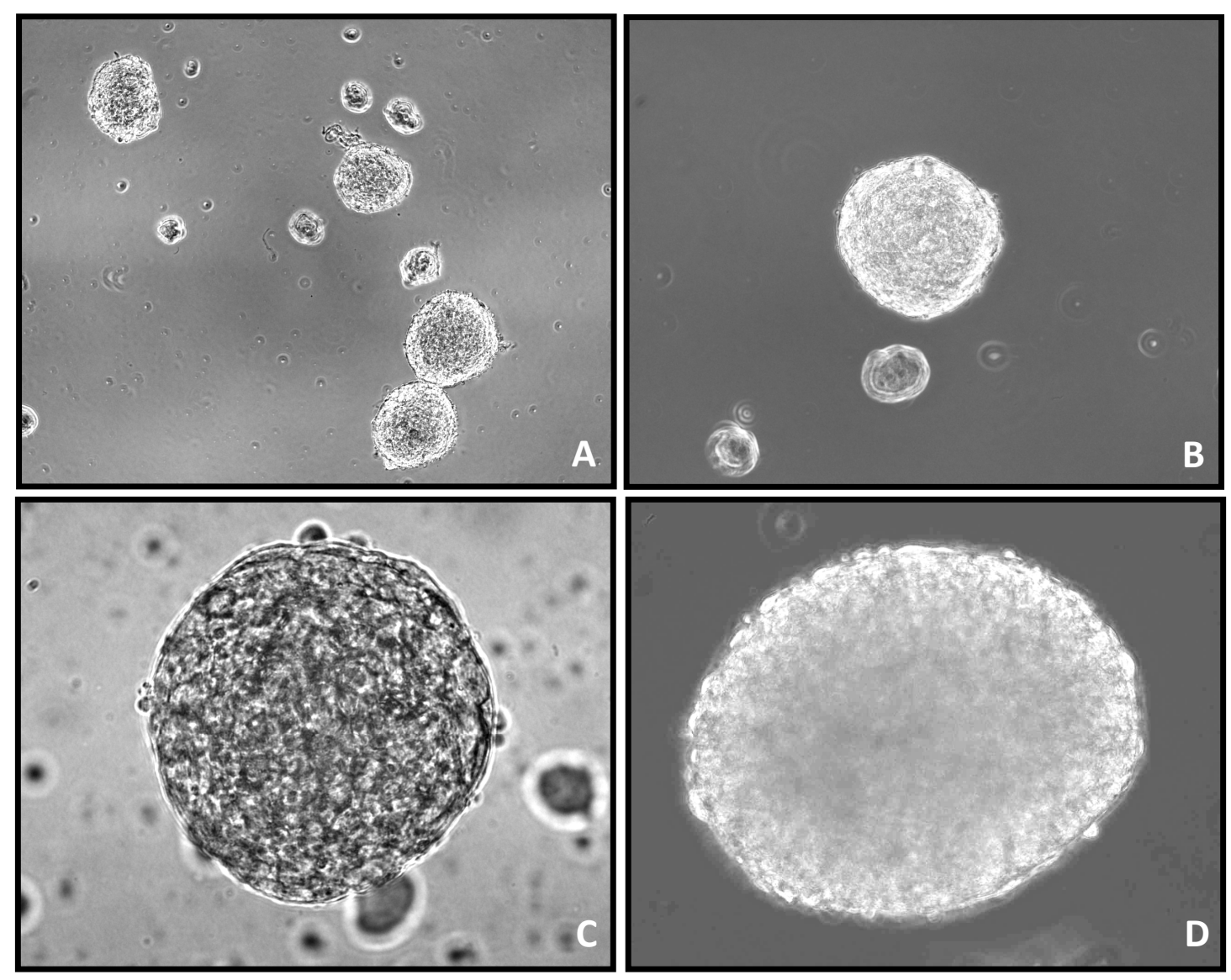

Neuroesferas formadas em suspensão. A-B) objetiva 10x. C-D) - objetiva 20x. 


\subsubsection{Adesão das Neuroesferas}

Após a formação das neuroesferas, foi necessária a transferência destas estruturas para outra placa de cultivo, na qual as mesmas pudessem se aderir para a indução da diferenciação retinal, bem como para sua avaliação. Foram então feitas adaptações no protocolo de cultivo, para que a esfera pudesse aderir à lamínula. Dois dias após a transferência das estruturas, já era possível visualizar as primeiras células que migravam das esferas. Tais células possuíam morfologia diferente das fibroblast-like típica das CTIPD indiferenciadas, sugerindo que as mesmas apresentavam um início de comprometimento com a linhagem neural.

Figura 15 - Neuroesferas Aderidas
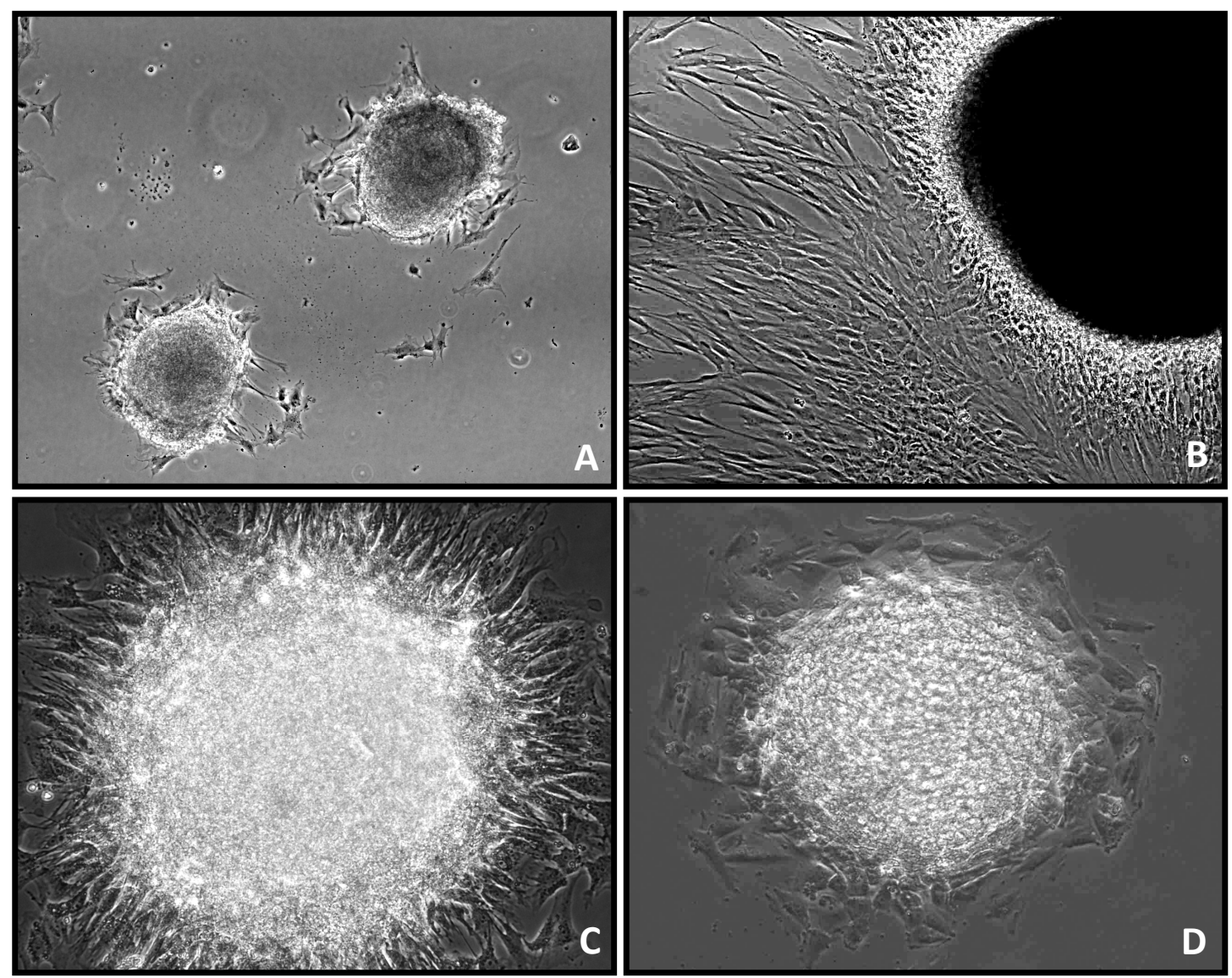

Neuroesferas aderidas à placa, liberando células que já não apresentam morfologia fibroblast-like. A) objetiva 10x. B-D) objetiva 20x. 


\subsubsection{Microscopia Eletrônica de Transmissão}

Realizamos em seguida a microscopia eletrônica de transmissão nas neuroesferas recém-formadas. Observamos que as mesmas foram compostas por células ainda indiferenciadas com núcleos grandes e pouco citoplasma, o qual era pobre em organelas intracelulares. Entre as células indiferenciadas, já nesta fase pudemos notar também a presença de células em processo de inicial de diferenciação. Estas células se caracterizavam também pela alta razão entre núcleo e citoplasma, típica de células precursoras ou não totalmente diferenciadas. As células apresentaram-se justapostas e com a formação de conexões intercelulares do tipo gap (do inglês "gap junction") evidenciada em maior aumento e a presença de microvilosidades nas células periféricas da esfera sugerindo um comprometimento com a linhagem neuroepitelial.

Figura 16 - Microscopia Eletrônica de Transmissão
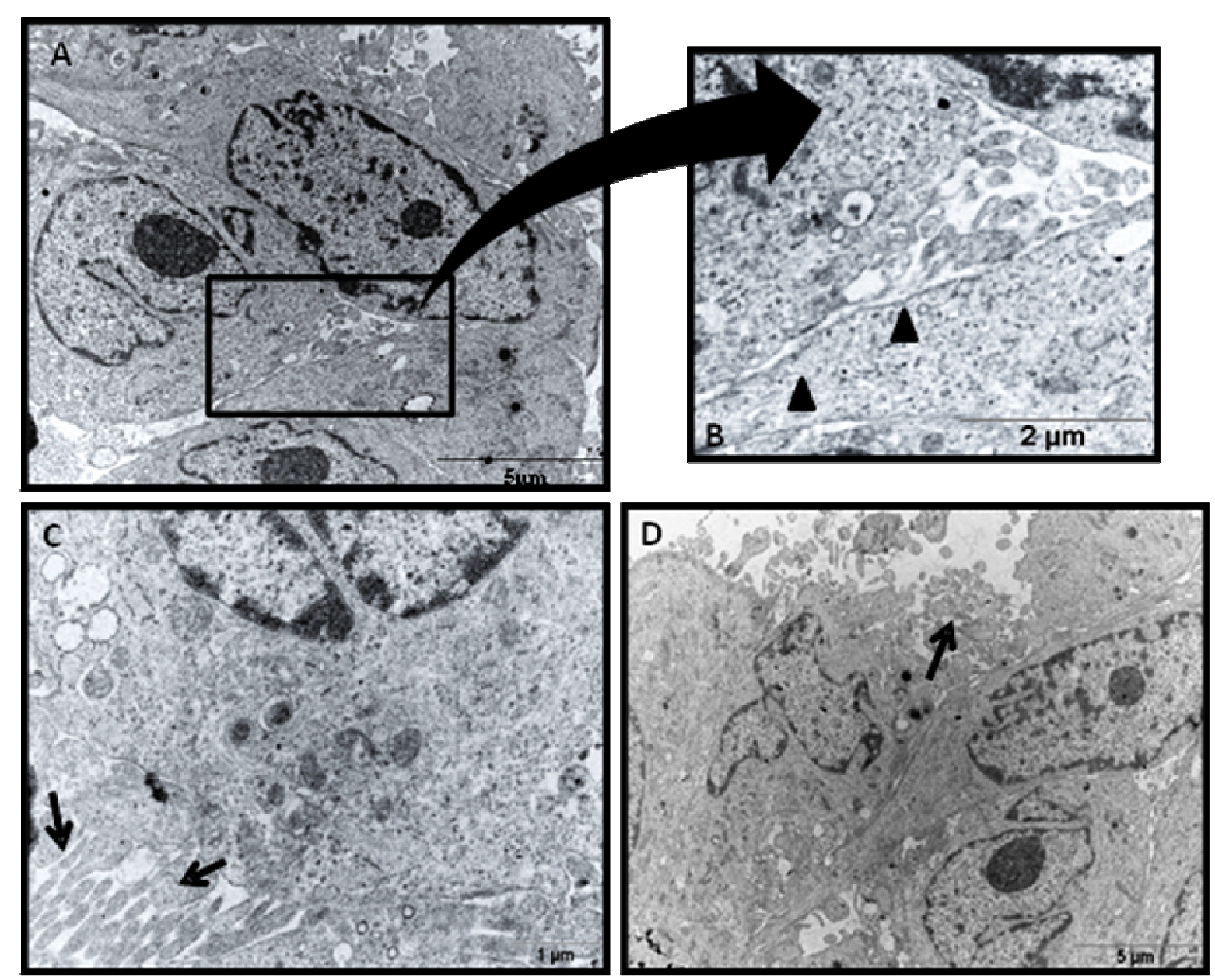

Microscopia eletrônica de transmissão das neuroesferas. A) Células em menor aumento com formação de junções "gap", evidenciada no destaque em aumento maior (B). C-D) Setas indicando as microvilosidades típicas de células neuroepiteliais. 


\subsubsection{Coloração das Neuroesferas com Hematoxilina/Eosina}

A fim de iniciar o processo de diferenciação retinal a partir das neuroesferas, fizemos com que estas se aderissem à placa de cultivo de acordo com o descrito na seção 4.6 desta dissertação. Porém neste ensaio utilizamos meio de diferenciação composto por neurobasal acrescido de 2\% B27 e ácido retinóico (5 uM). Após cinco dias, pudemos observar uma alteração significativa na morfologia das células que migravam da esfera, as quais apresentaram indícios de um comprometimento com a linhagem neural, como mostrado na figura 17. A fim de evidenciar esta morfologia, fixamos a esfera e as células, com formaldeído $4 \%$ e em seguida realizamos a coloração de Hematoxilina/Eosina (HE). Pudemos observar as células em um arranjo semelhante ao de uma rede celular, característico da linhagem neural, mais especificamente semelhante à células gliais, que ficaram evidentes pelo tamanho do corpo celular e principalmente pela emissão de prolongamentos entre as células.

Figura 17 - Neuroesferas Aderidas - Meio de Diferenciação

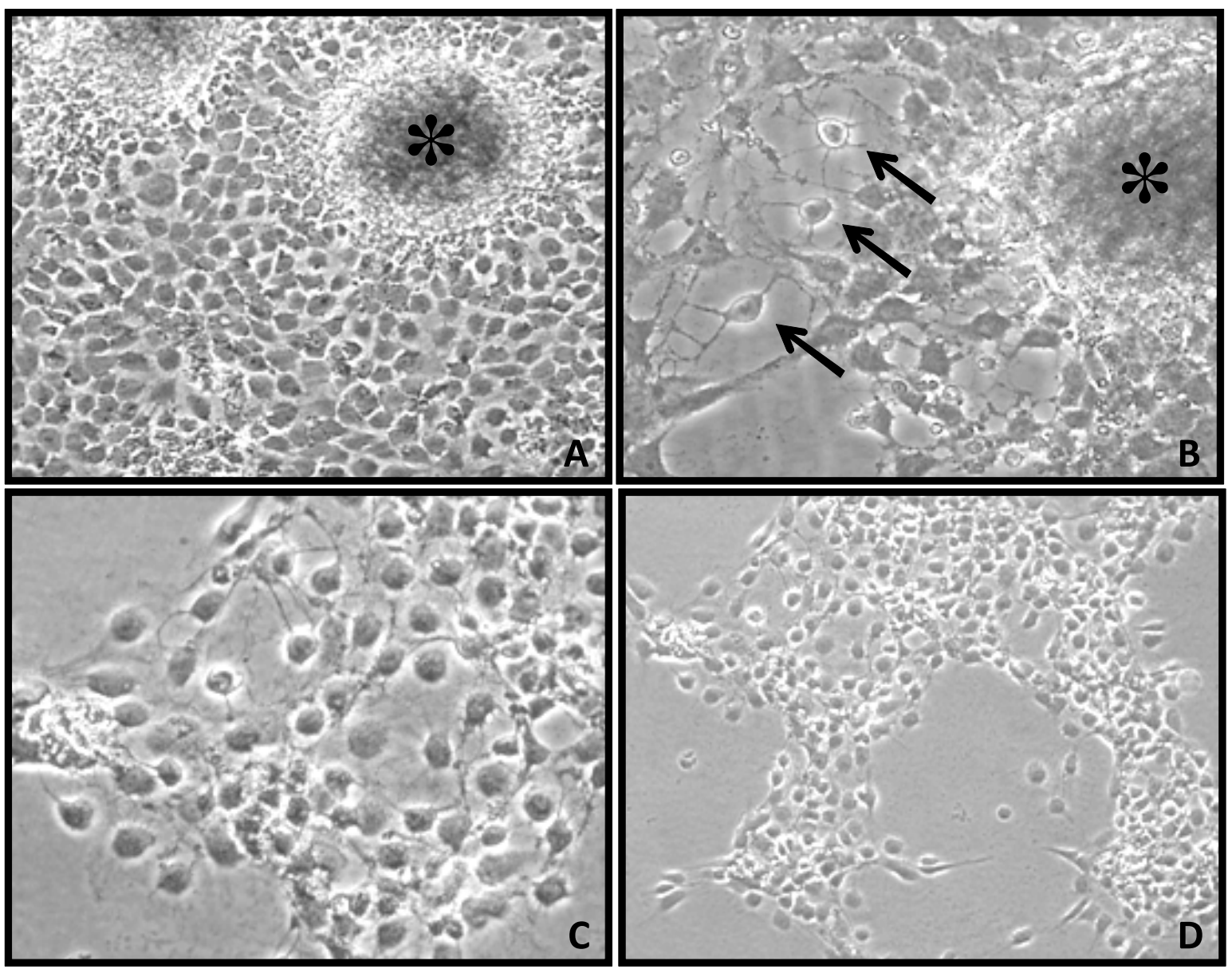

Neuroesferas aderidas em meio de diferenciação. A-B) Asteriscos indicam o centro da esfera e as setas mostram as células neurais-like que migram da esfera - objetiva 20x. C-D) Células mais distantes do centro da esfera, porém sem perder a morfologia neural-like - objetiva 10x. 
Figura 18 - Coloração das Neuroesferas com Hematoxilina/Eosina
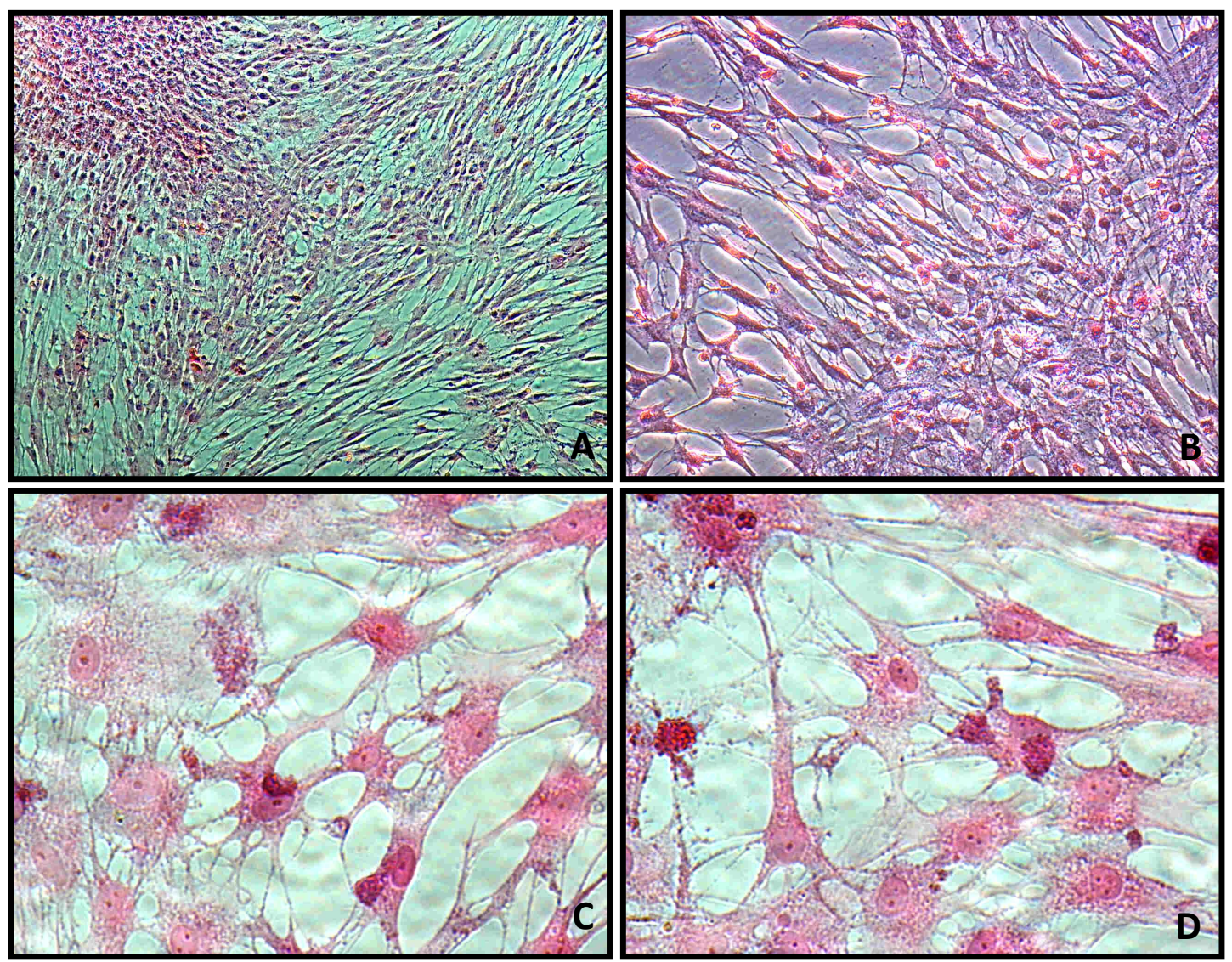

Neuroesferas aderidas liberando células com morfologia glial-like coradas com HE. A) objetiva 10x. B) objetiva 20x. C-D) objetiva 60x.

\subsubsection{Imunofluorescência nas Neuroesferas}

Após a formação e adesão das neuroesferas, foram realizadas análises por imunofluorescência para verificar a expressão de progeniotres neurais/retinais. Verificamos a expressão positiva de $\beta$-III-Tubulin na periferia das esferas, sugerindo a presença de células comprometidas com a linhagem neural. Enquanto a expressão de nestin, observada preferencialmente no centro das esferas, sugere a presença de precursores neurais menos diferenciados. Também foi possível verificar a expressão positiva para o Pax-6, um marcador de precursor retinal de extrema importância para o desenvolvimento ocular. 
Figura 19 - Imunofluorescência - Neuroesferas
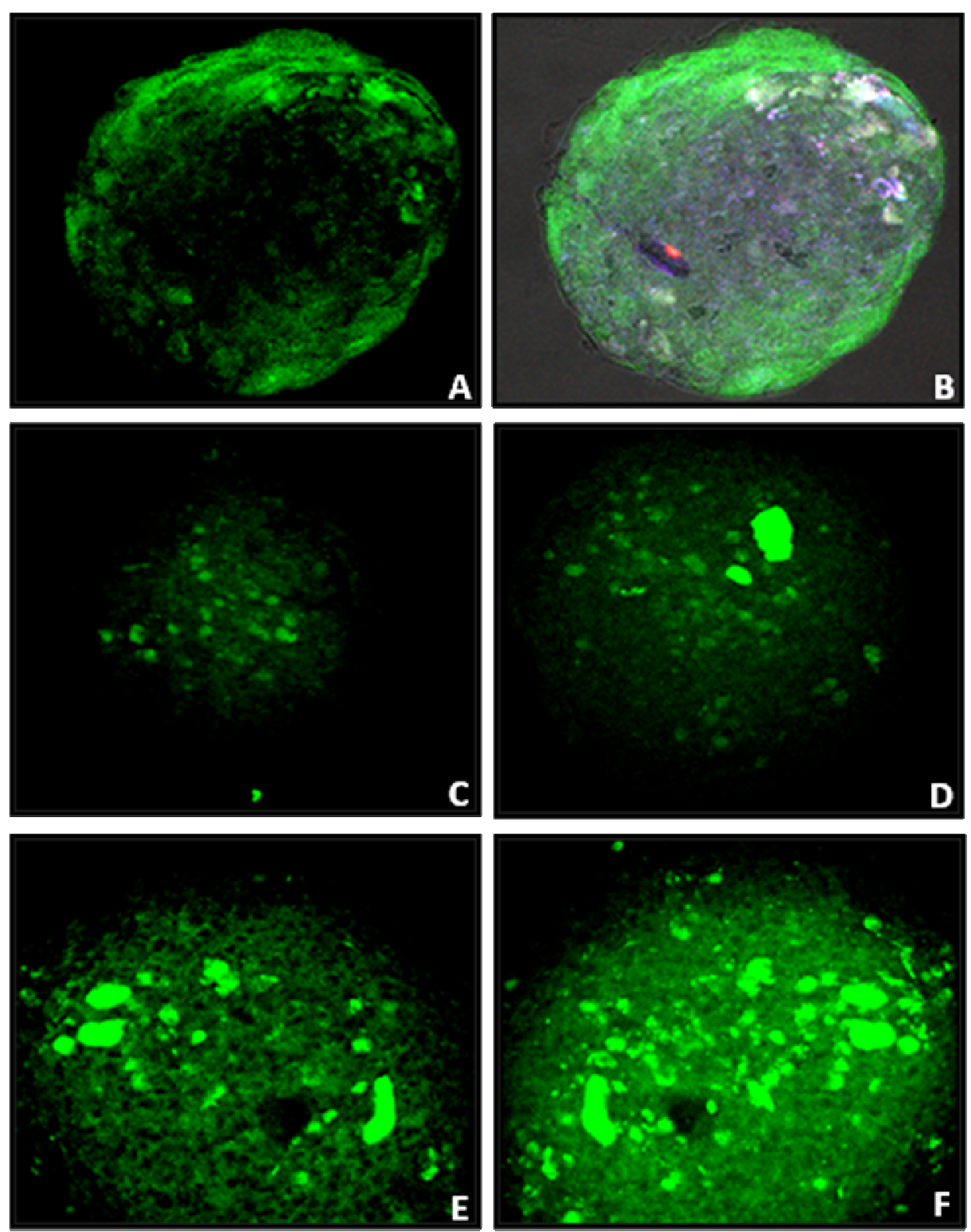

A-B) Marcação positiva de $\beta$-III-Tubulin na periferia das neuroesferas. C-D) Expressão positiva de nestin no centro das esferas. E-F) Expressão de Pax-6 nas neuroesferas, sugerindo o início de um comprometimento com a linhagem retinal. A-F) objetiva 40x.

\subsubsection{Co-cultivo das CTIPD com Células do EPR}

$\mathrm{Na}$ tentativa de realizar a diferenciação retinal a partir das neuroesferas, estas foram mantidas em co-cultivo sobre as células do EPR por cinco dias em dois diferentes meios de cultivo. Pudemos notar uma significativa diferença na morfologia de ambas as células do EPR e da neuroesfera. No cultivo com meio condicionado pelo EPR (Figura 20 - A-B) as células pigmentares apresentaram uma morfologia fusiforme, mais alongada, enquanto as células da 
neuroesfera não foram capazes de migrar pelo EPR. Já no cultivo com meio neurobasal (Figura 20 - C-D), as células do EPR apresentaram morfologia epitelial, com células mais arredondadas, características desta linhagem e as células da neuroesfera foram capazes de se soltar e migrar sobre o EPR inativado. Após 10 dias, ambas as esferas tinham liberado todas as células, as quais se fundiram com as células do EPR.

Figura 20 - Co-cultivo das CTIPD com EPR

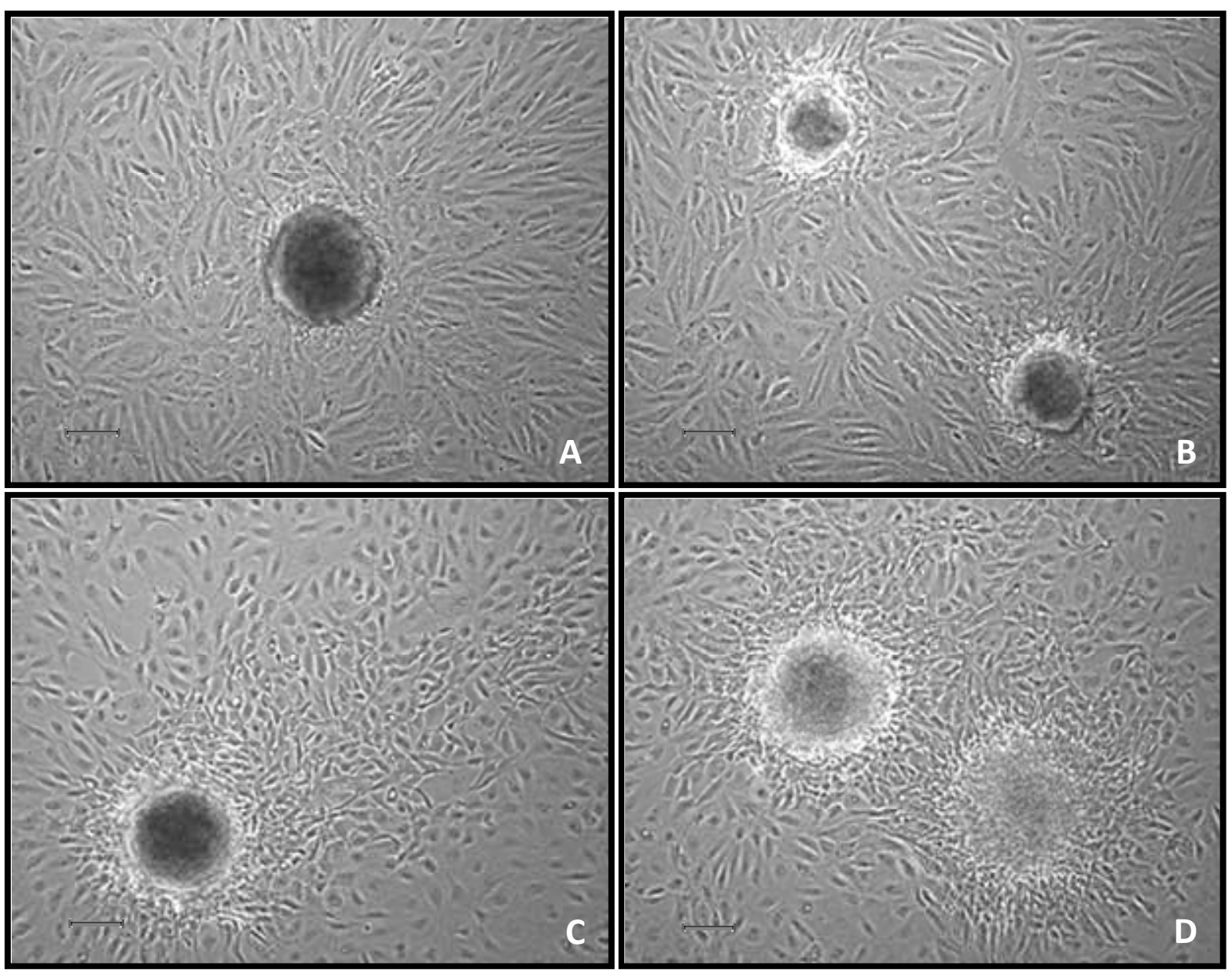

Neuroesferas em co-cultivo com as células do EPR. A-B) Cultivo em meio condicionado pelo EPR - objetiva 10x. C-D) Cultivo em meio neurobasal - objetiva 10x.

\subsubsection{Desagregação das Neuroesferas}

Como método alternativo para obtenção da diferenciação retinal, decidimos testar diferentes meios de cultivo indutores. Utilizamos neuroesferas formadas há quatro dias, as quais foram desagregadas e plaqueadas em seis diferentes meios de cultivo, previamente 
descritos na seção 4.10 - Materiais e Métodos. Estes meios foram subdivididos em três grupos. Pudemos notar uma significante variação entre a morfologia das células dos três grupos, porém dentro dos grupos, os indutores não foram responsáveis por alterações morfológicas significativas. No grupo 1 as células se mostraram bastante afiladas e cresceram menos em relação aos demais grupos. No grupo 2 pudemos observar maior quantidade de células porém com morfologia diferente dos grupos 1 e 3 e semelhante a células comprometidas com o início da diferenciação osteogênica. O grupo 3 foi o mais satisfatório, com uma boa quantidade celular, morfologia também afilada e mais próxima da linhagem neuronal. 
Figura 21 - Desagregação das Neuroesferas
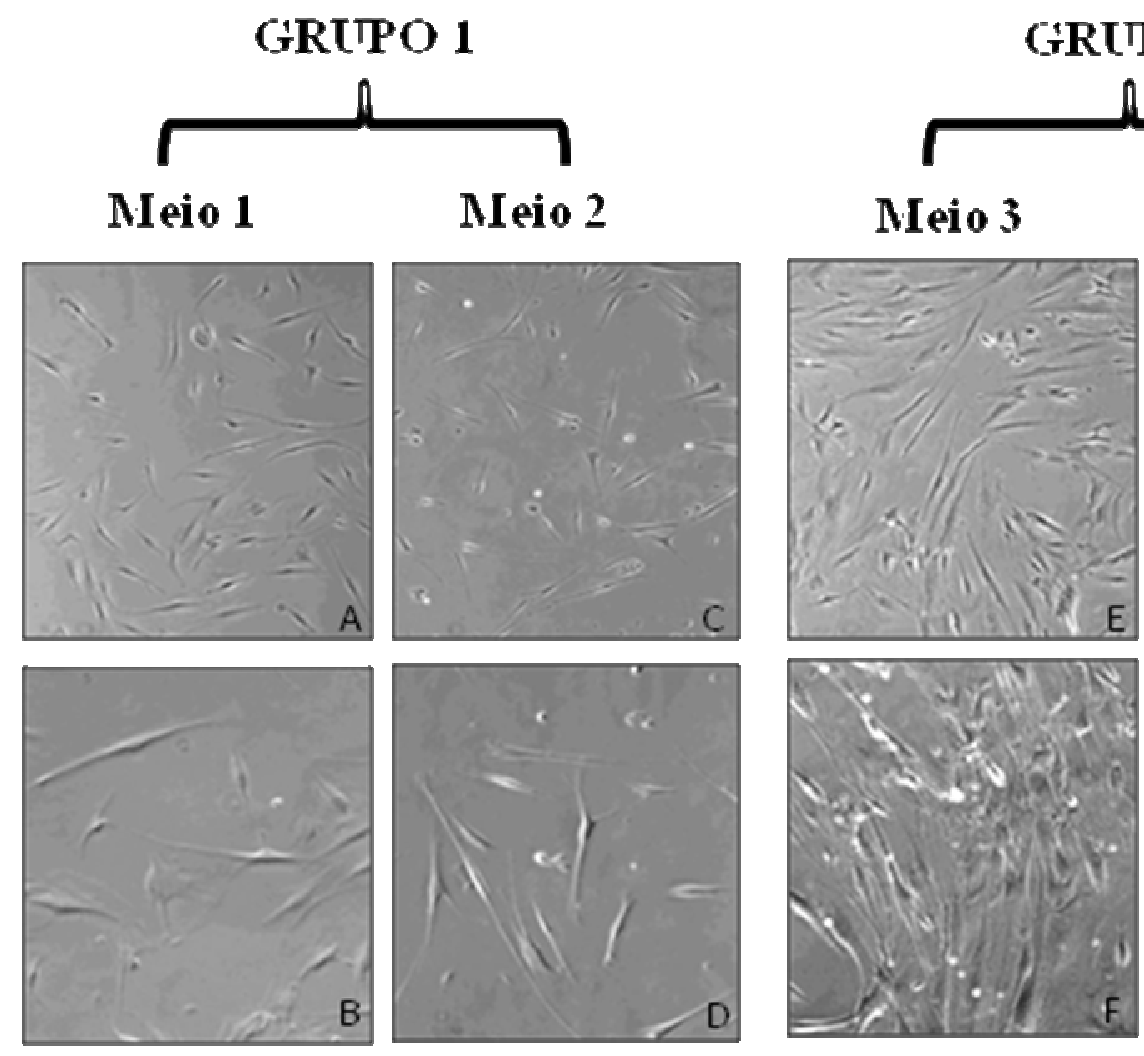

\section{GRIPO 2}
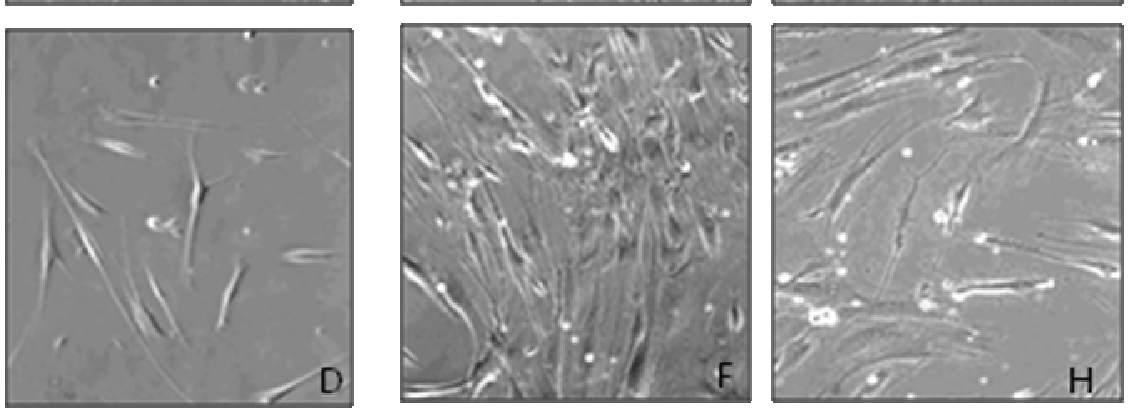

Meio 4

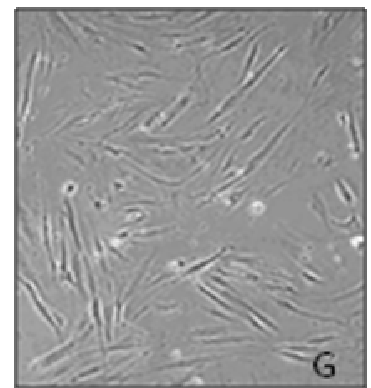

\section{GRIPO 3}

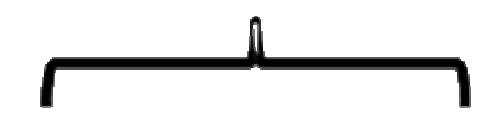

Meios

Meio 6
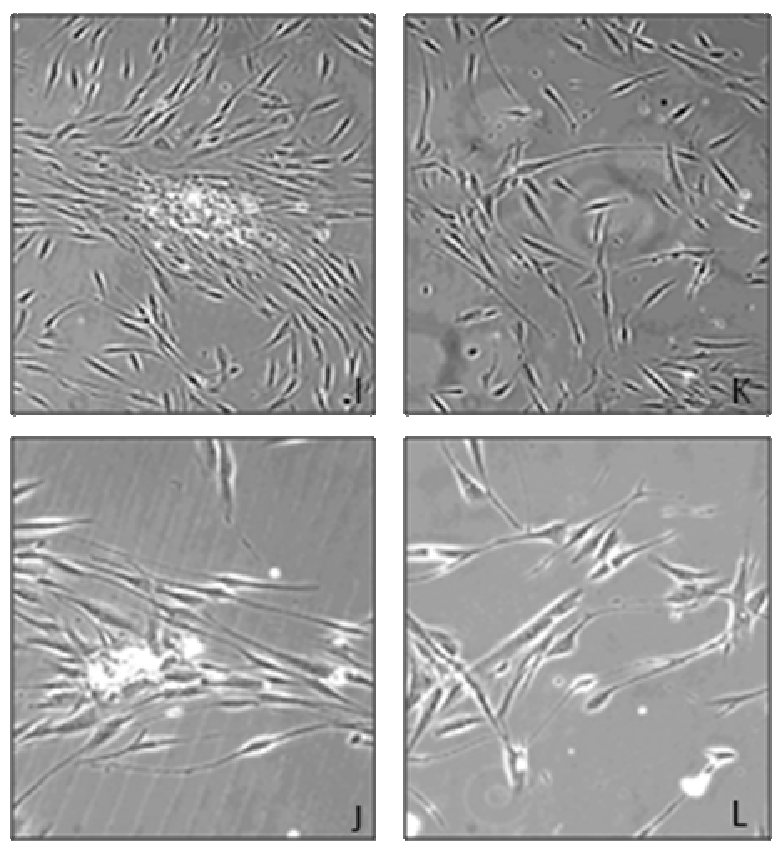

Neuroesferas desagregadas e plaqueadas em diferentes meios de cultivo e indutores. A-D) Meio Neurobasal. EH) Meio condicionado pelo EPR e Meio Neurobasal na proporção 1:1. I-L) Meio condicionado pelo EPR. A,C,E,G,I e K - objetiva 10x. B,D,F,H,J e L - objetiva 20x. 


\subsubsection{Diferenciação Direta das CTIPD em Células Neural-like}

$\mathrm{Na}$ tentativa de realizar a diferenciação retinal evitando o estágio de neuroesfera, as CTIPD foram plaqueadas diretamente em meio neurobasal e mantidas por 21 dias. No início do cultivo, as células mantiveram morfologia semelhante à células mesenquimais, porém a partir do $15^{\circ}$ dia, as células passaram a adquirir características de células neurais, como perda de citoplasma, núcleos deslocados e refringentes, emissão de prolongamentos e conexões intercelulares.

Foi então realizado um ensaio de imunofluorescência para avaliar o perfil celular obtido utilizando os marcadores da diferenciação retinal e alguns marcadores da diferenciação neural. Embora morfologicamente as células estivessem condizentes com a diferenciação neural, o resultado da imunofluorescência demonstrou que tais células não apresentaram expressão de nenhum marcador de diferenciação retinal, sendo positivas apenas para $\beta$-IIITubulin e para o marcador glial GFAP. 
Figura 22 - Diferenciação Direta das CTIPD em Células Neural-like
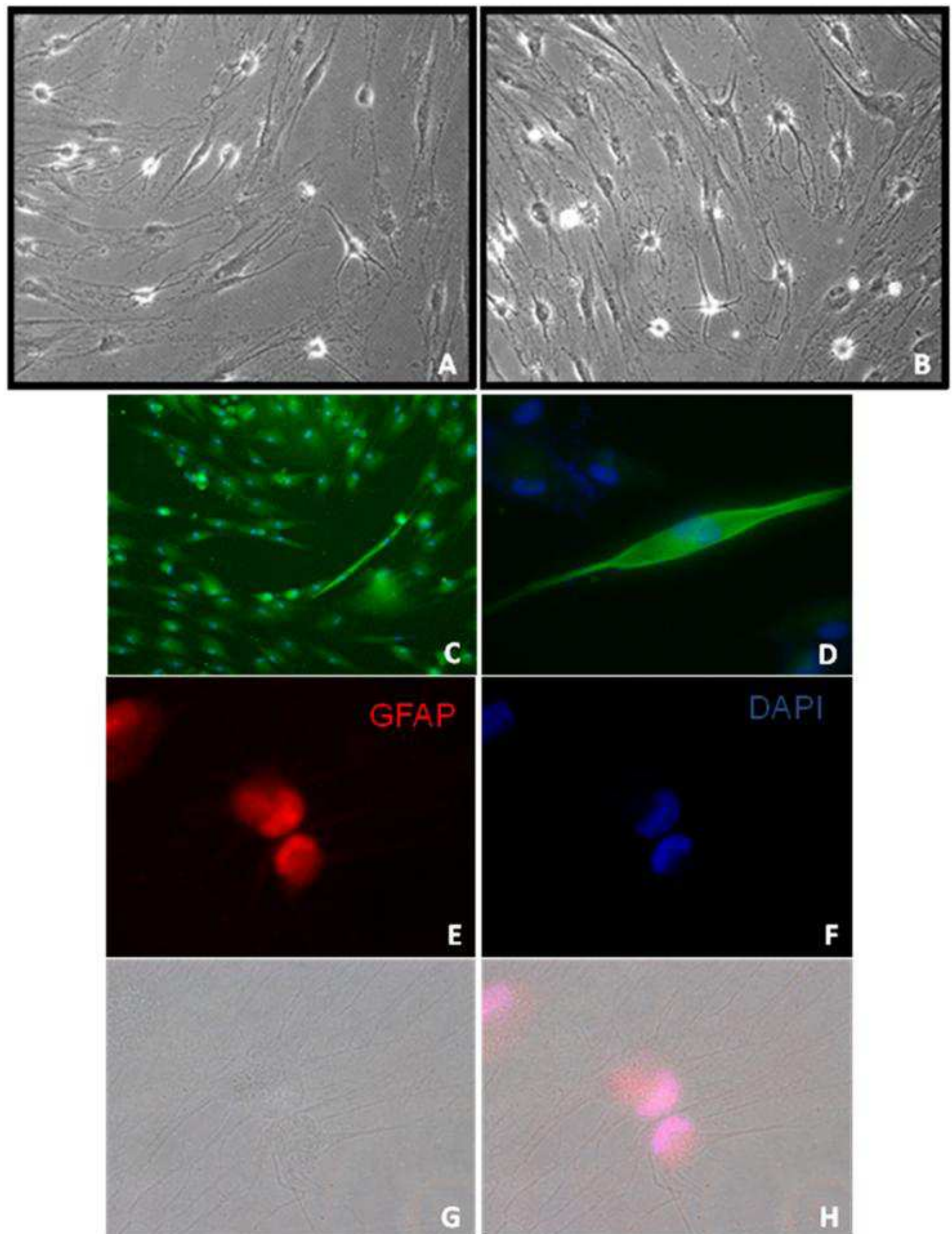

A-B) Contraste de fase mostrando células com morfologia glial-like - objetiva 10x. C-D) Imunofluorescência mostrando expressão de $\beta$-III-Tubulin - C) objetiva 10x. D) objetiva 60x. E-H) Expressão postiva de GFAP objetiva 40x. E) GFAP marcando corpo e núcleo celular. F) Núcleos corados com DAPI. G) Campo claro demonstrando a morfologia glial-like das células. H) Sobreposição de todos os filtros (Rodamina + DAPI + Campo claro). 


\subsubsection{Diferenciação das Neuroesferas em Neurônios Retinais}

Como a tentativa de diferenciação retinal anterior (seção 5.4.8) não demonstrou resultados satisfatórios, voltamos a realizar os testes de diferenciação a partir das neuroesferas como inicialmente programado. As neuroesferas formadas e posteriormente aderidas liberaram células em grande quantidade, dentre as quais, algumas apresentaram morfologia semelhante a neurônios. Após aproximadamente cinco dias de cultivo, nós observamos que as neuroesferas quando aderidas, não preenchiam a placa de maneira homogênea, apresentando espaços muito concentrados, como ao redor da esfera, e espaços muito vazios na periferia da placa, então notamos a necessidade de um repique para que as células pudessem ser distribuídas de maneira homogênea. No intuito de aumentar a quantidade celular e enriquecer a nossa cultura com as células com comprometimento neuronal, cultivamos estas células em meio neurobasal + B27 e AR por dez dias. As células apresentaram uma morfologia semelhante aos diferentes tipos de células neuronais. 
Figura 23 - Diferenciação das Neuroesferas em Neurônios Retinais
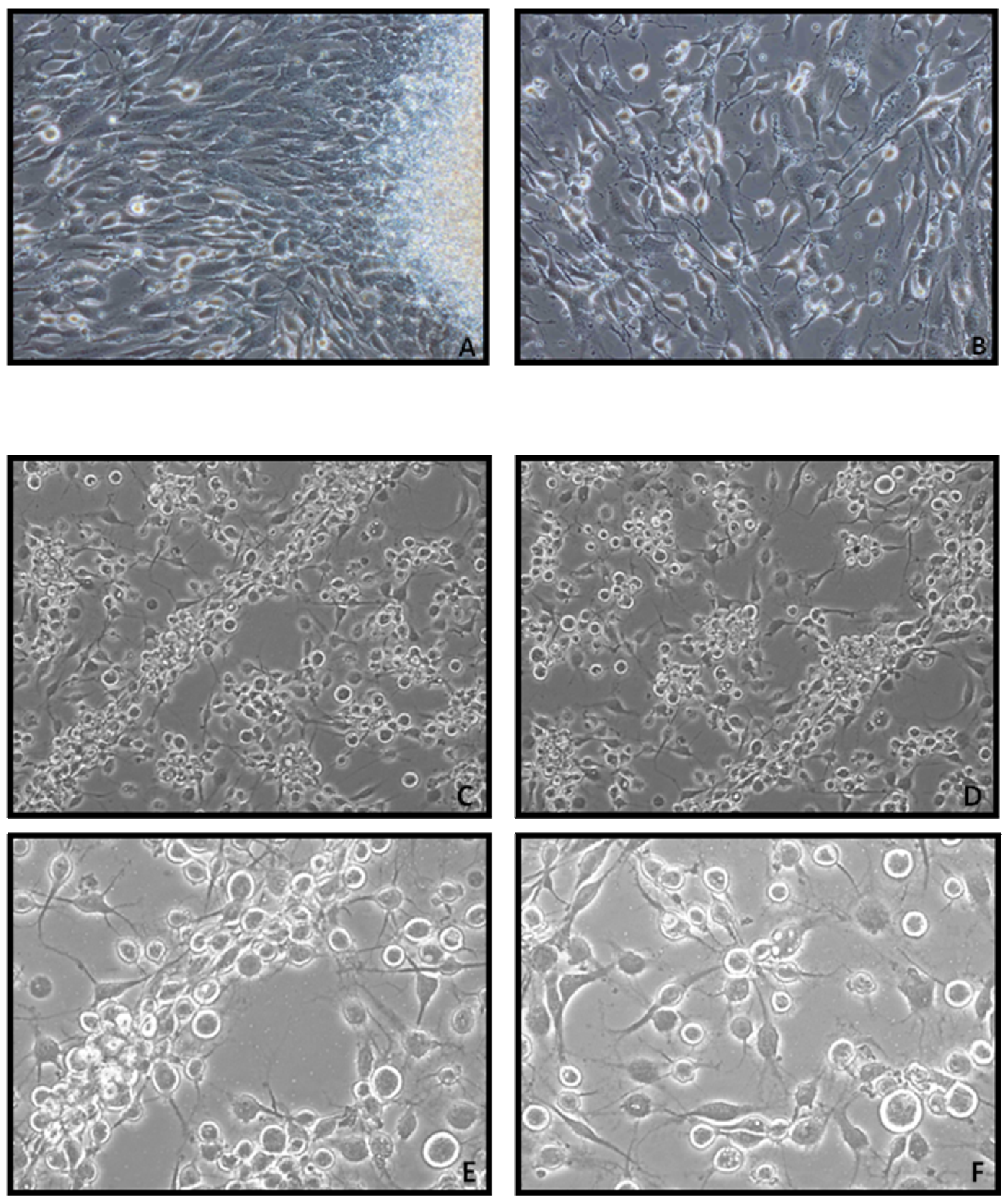

Contraste de fase mostrando a diferenciação das neuroesferas em neurônios-símile. A-B) Neuroesferas aderidas mostrando a confluência ao redor da esfera e as células com morfologia neuronal-like que migram da esfera objetiva 10x. C-F) Após o repique as células aderem de maneira mais uniforme porém com dois tipos bastante distintos quanto à morfologia: células arredondadas menos aderidas e células semelhante à glia mais fortemente aderidas. C-D) Objetiva 10x. E-F) Objetiva 20x. 
Quando utilizamos uma quantidade de células e um tempo de dissociação enzimática menor pudemos verificar que dependendo desta variante, o resultado pode ser bastante diferente. Observamos que nessas condições ocorre a formação de neuroesferas secundárias, as quais apresentaram morfologia muito semelhante às neuroesferas que podem ser obtidas a partir de células neuronais do próprio SNC ou a partir de células tronco embrionárias. As estruturas formadas são pequenos aglomerados celulares em suspensão, sem formato definido, que quando deixados em cultura somente em meio Neurobasal, sem troca de meio, aderem à lamínula após dois dias. Em seguida, podem ser observadas células típicas neuronais ao redor destas estruturas aderidas, denominadas rosetas. 
Figura 24 - Diferenciação das Neuroesferas em Neurônios Retinais - Rosetas
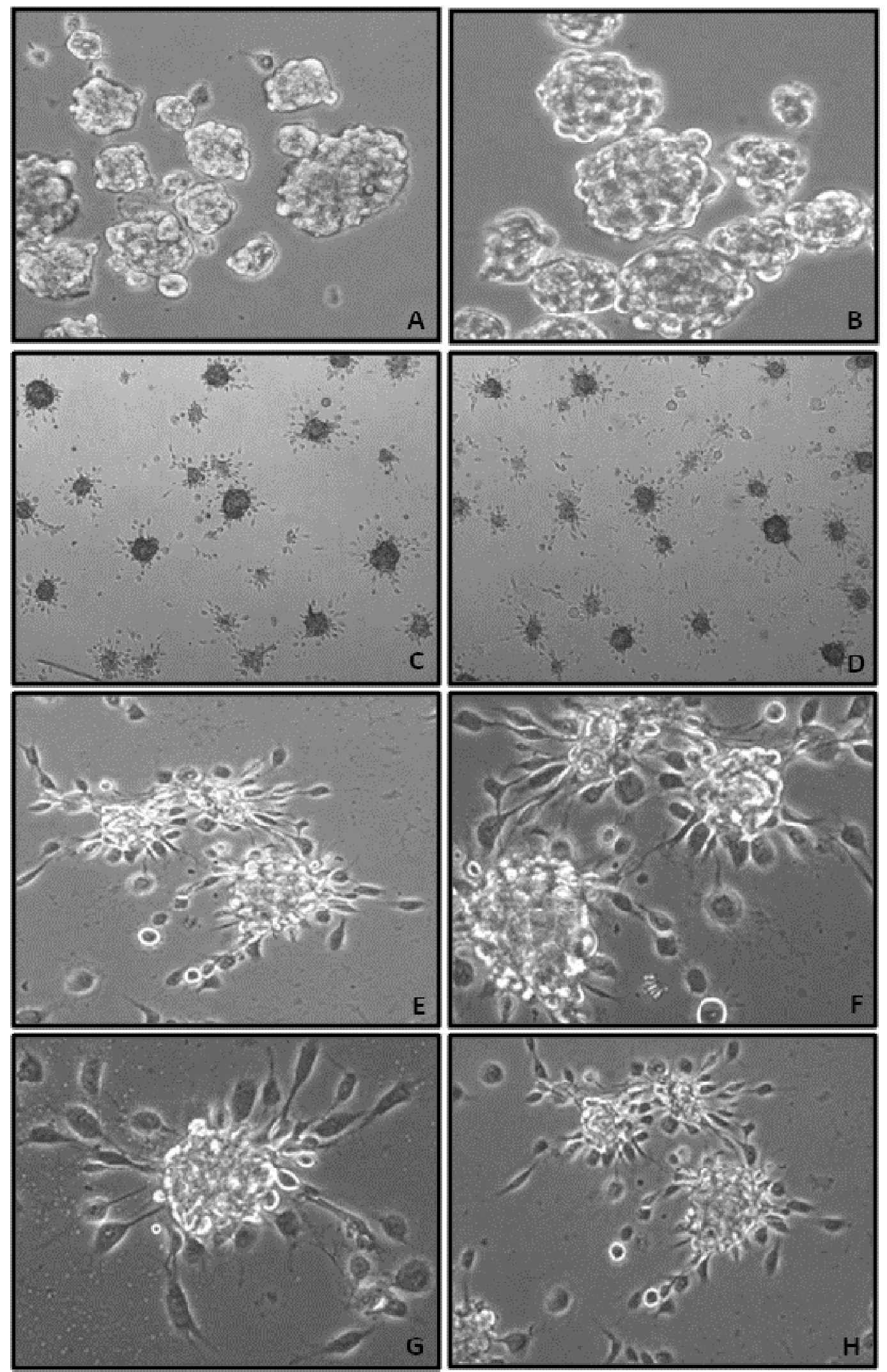

A-B) Neuroesferas secundárias em suspensão - objetiva 20x. C-D) Neuroesferas secundárias aderidas - objetiva 10x. E-H) Neuroesferas aderidas mostrando as células com morfologia neural-like - objetiva 20x. 


\subsubsection{Imunofluorescência - Avaliação das Células Diferenciadas}

Para avaliarmos as células diferenciadas, realizamos um ensaio de imunofluorescência, primeiramente verificando a expressão de CD73, o qual havia sido avaliado também antes do processo de diferenciação. Realizamos também a avaliação por imunofluorescência para os marcadores específicos da diferenciação retinal como Pax-6, Chx10, Crx, Nrl, Calbindin, Rhodopsin e Recoverin. Os resultados estão apresentados a seguir de acordo com os marcadores:

- CD73: CD73, também conhecido como ecto-5'-nucleotidase, cataliza a conversão extracelular de 5'-adenosina monofosfatase em adenosina. É um marcador de superfície celular, tanto de precursores de cones, como de bastonetes. Sua localização está geneticamente localizada entre Crx e Nrl (KOSO et al., 2009). 
Figura 25 - Imunofluorescência - CD73
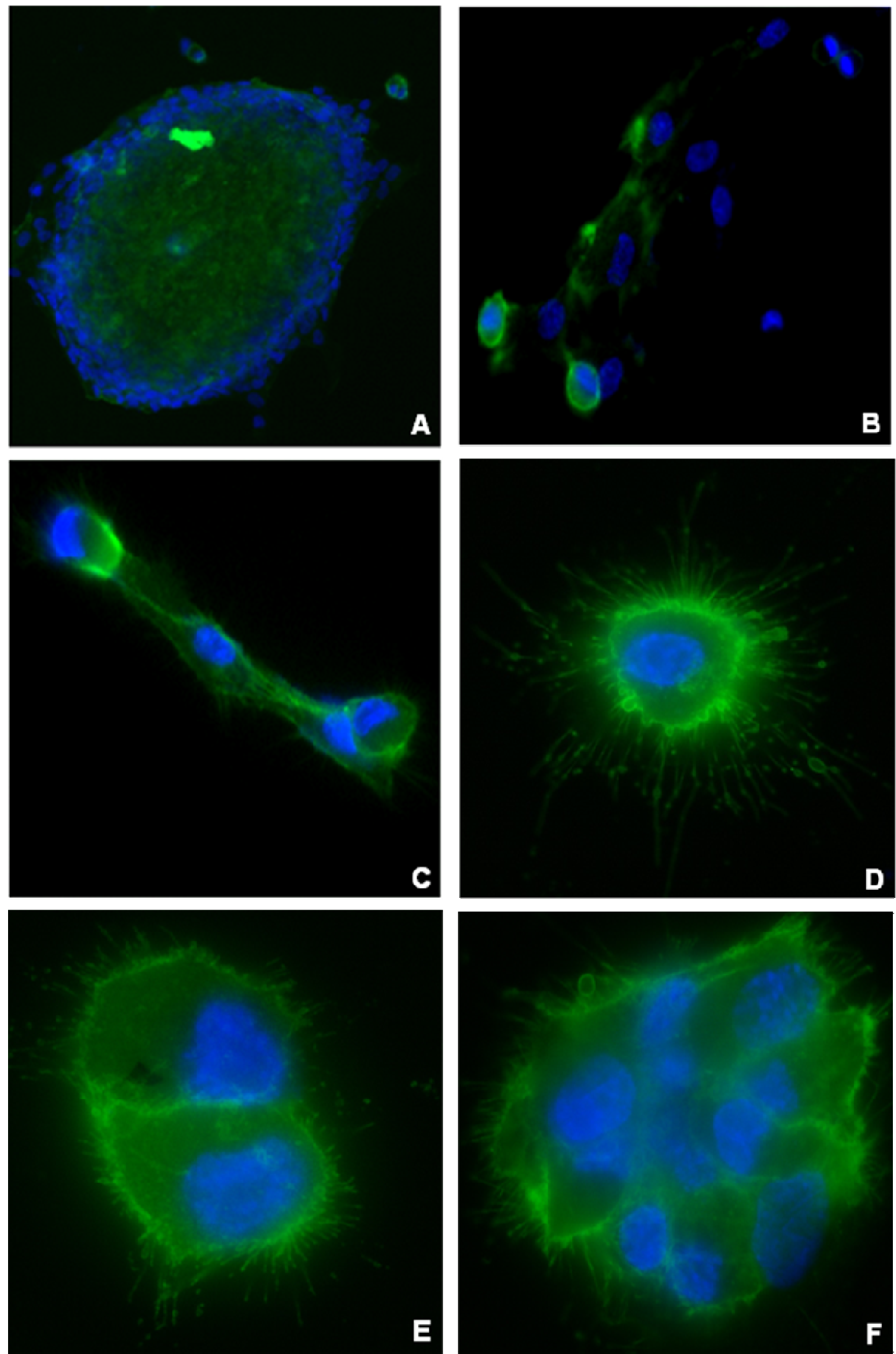

Expressão positiva de CD73 nas CTIPD pós-diferenciação retinal. A-D) objetiva 40x. E-F) objetiva 100x. Núcleos corados com DAPI. 
- NESTIN: é uma proteína de filamento intermediário expressa em células progenitoras neurais e em células neuroepiteliais. Sua expressão ocorre preferencialmente no citoplasma celular.

Figura 26 - Imunofluorescência - NESTIN
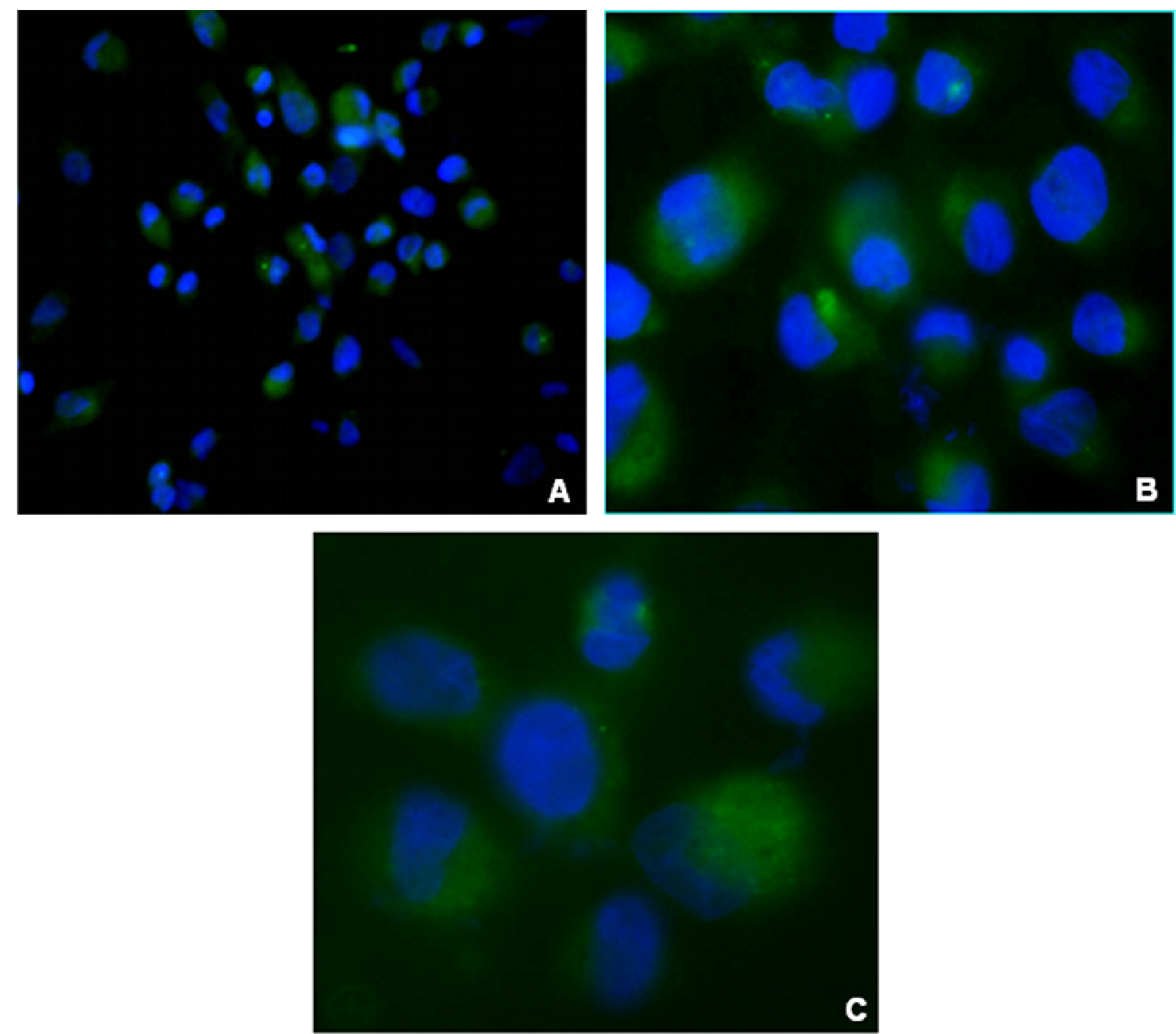

Expressão positiva de nestin nas CTIPD pós-diferenciação retinal. A-C) objetiva 100x. Núcleos corados com DAPI. 
- PAX-6: Por se tratar de um fator de transcrição, a expressão ocorre mais intensamente na região nuclear e perinuclear. Em células precursoras, a expressão citoplasmática também pode ser visualizada devido à alta razão entre núcleo e citoplasma característico deste estágio de diferenciação. A expressão também não ocorre de maneira sincronizada, ou seja, pode ocorrer mais intensamente em algumas células, assim como existem muitas células que são negativas para expressão deste marcador, dependendo do estágio de maturação que se encontram.

Figura 27 - Imunofluorescência - PAX-6
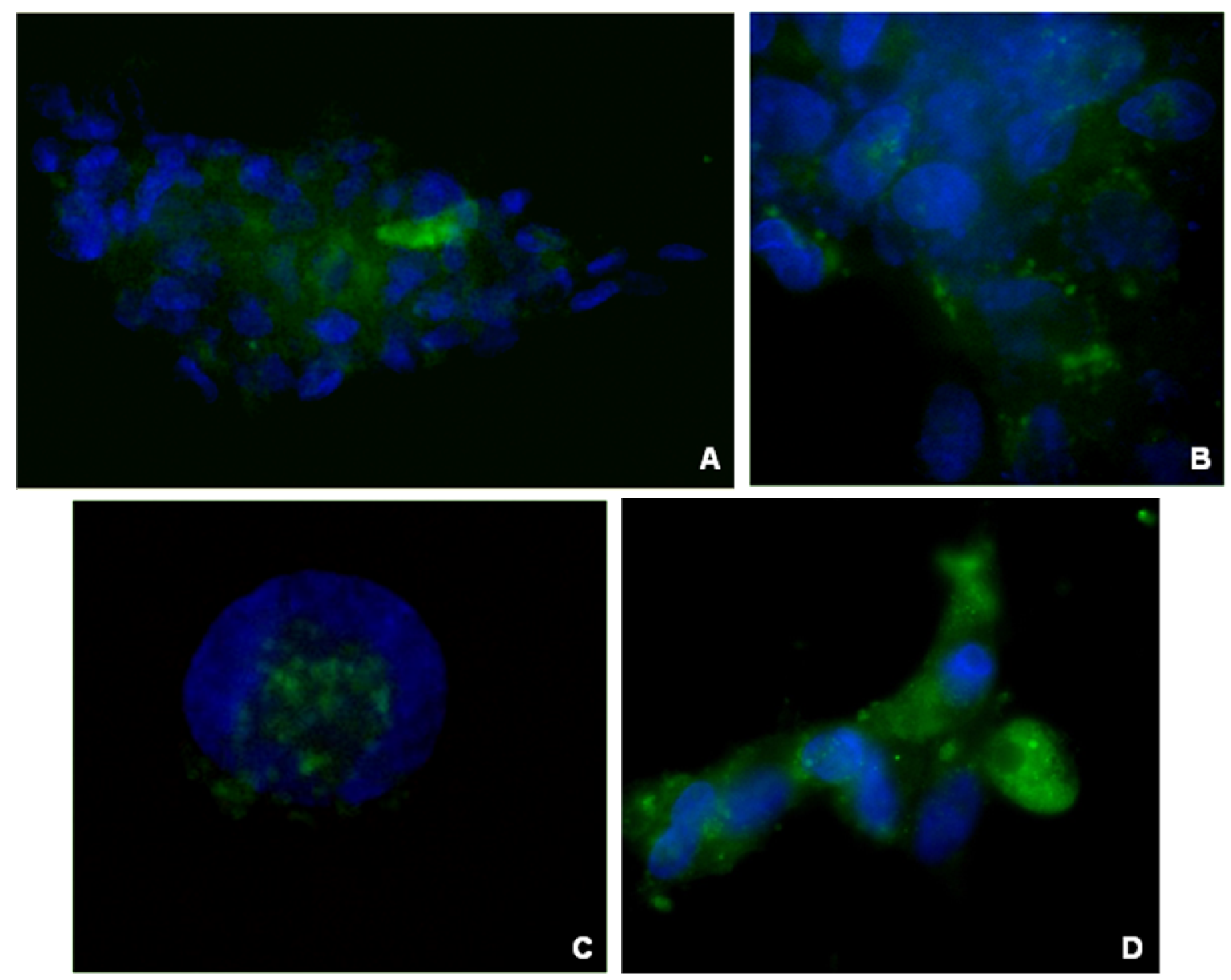

Expressão positiva de Pax-6 nas CTIPD pós-diferenciação retinal. A-C) objetiva 100x. Núcleos corados com DAPI. 
- CHX-10: Assim como Pax-6, Chx-10 também é um fator de transcrição envolvido na diferenciação de precursores retinais recentes no desenvolvimento. Chx-10 ativa o fator de transcrição Crx. Quando comparado à expressão de Pax-6, tanto a intensidade da expressão, como a quantidade de células marcadas, foi bem maior para o Chx-10.

Figura 28 - Imunofluorescência - CHX-10
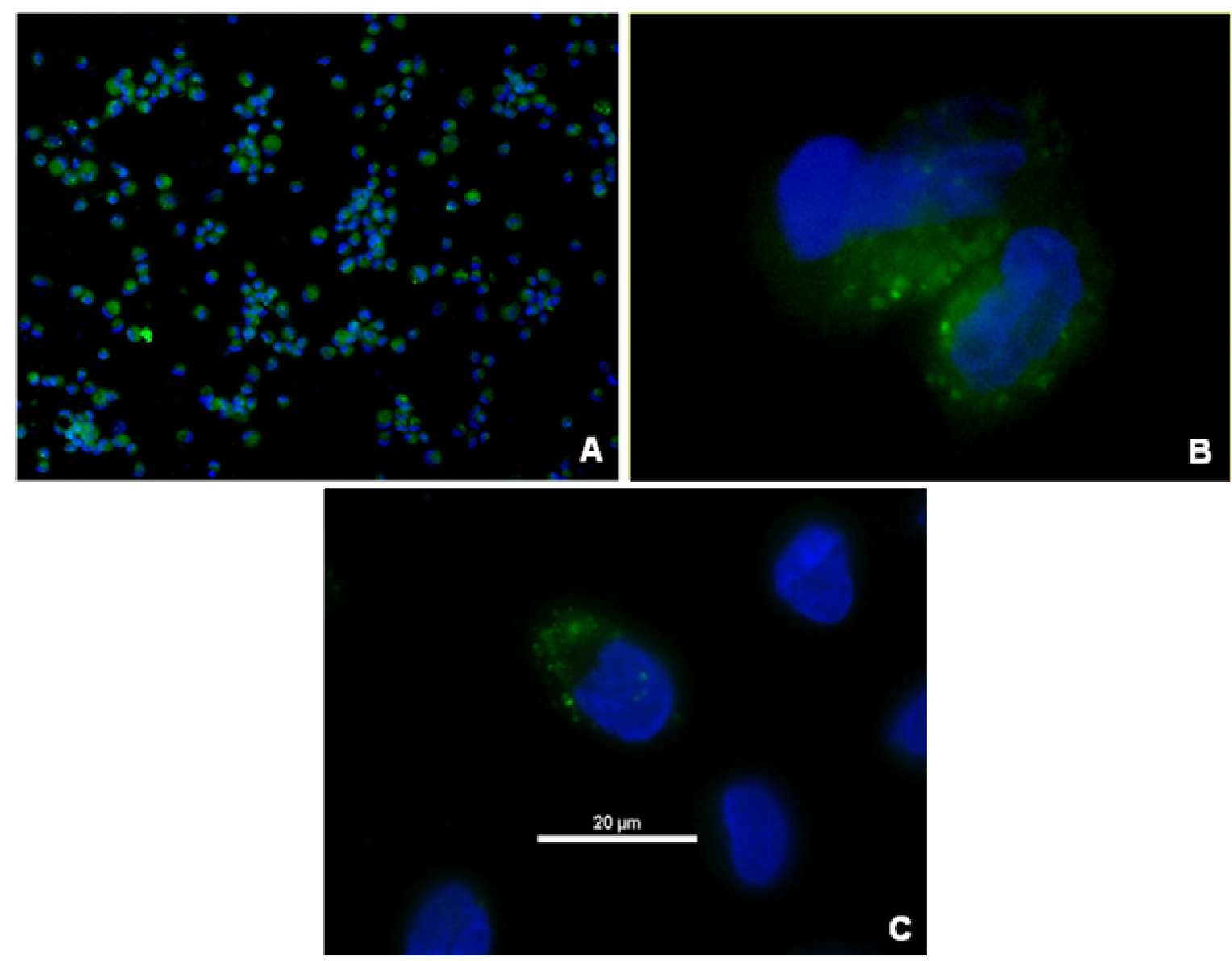

Expressão positiva de Chx-10 nas CTIPD pós-diferenciação retinal. A) objetiva 20x. B-C) objetiva 100x. Núcleos corados com DAPI. 
- CRX: é considerado um marcador de precursor de fotorreceptores, tendo sua expressão no núcleo e região perinuclear. O gene Crx codifica um fator de transcrição que coordena a expressão de fotorreceptores e sendo assim Crx ativa outro fator de transcrição, o Nrl. A presença citoplasmática deste fator também é observada pela alta razão núcleo/citoplasma destas células.

Figura 29 - Imunofluorescência - CRX
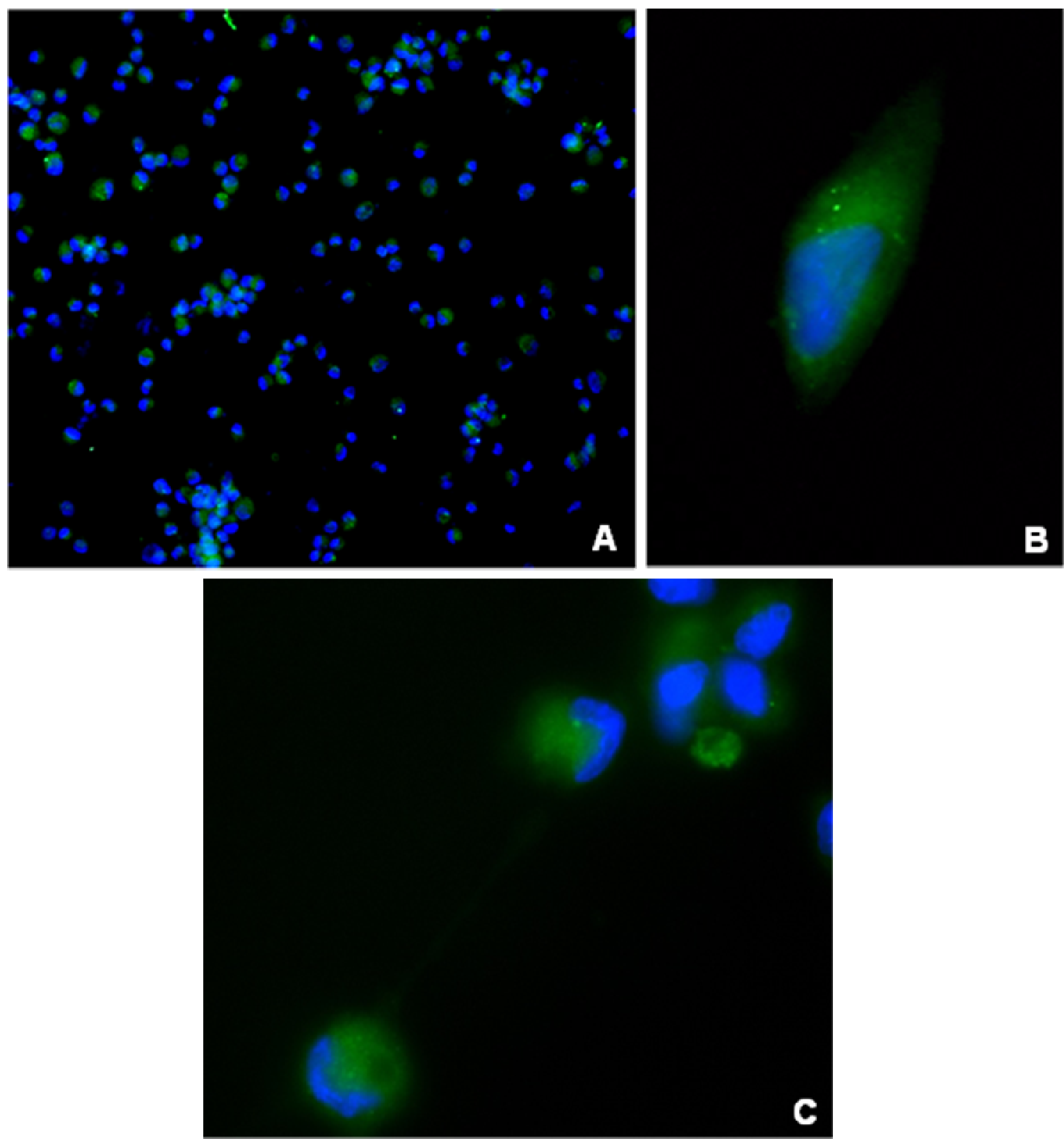

Expressão positiva de Crx nas CTIPD pós-diferenciação retinal. A) objetiva 20x. B-C) objetiva 100x. Núcleos corados com DAPI. 
- NRL: é um fator de transcrição expresso em neurônios retinais, mais intensamente na região nuclear e perinuclear e que promove a expressão de rhodopsin através da sua ligação no promotor do gene rhodopsin. É expresso em todo o sistema nervoso central e periférico durante o desenvolvimento, mas na vida adulta fica restrito ao neocórtex e neurônios retinais.

Figura 30 - Imunofluorescência - NRL
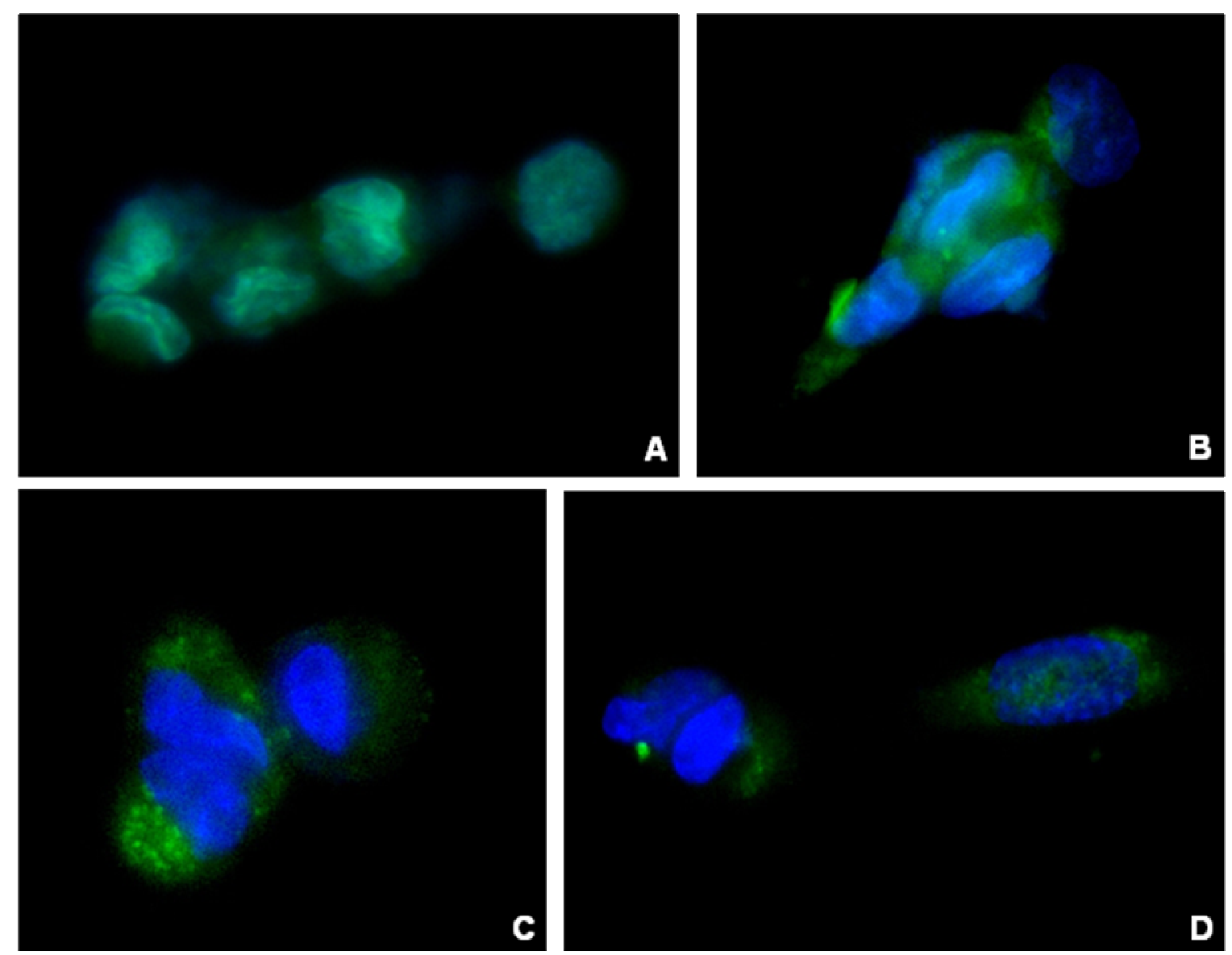

Expressão positiva de Nrl nas CTIPD pós-diferenciação retinal. A-C) objetiva 100x. Núcleos corados com DAPI. 
- CALBINDIN: Calbindin é também conhecido como uma proteína ligante de cálcio dependente de vitamina $\mathrm{D}$ e é expressa em tecidos neurais assim como nas células horizontais da retina. Sua expressão ocorre no citoplasma celular.

Figura 31 - Imunofluorescência - CALBINDIN
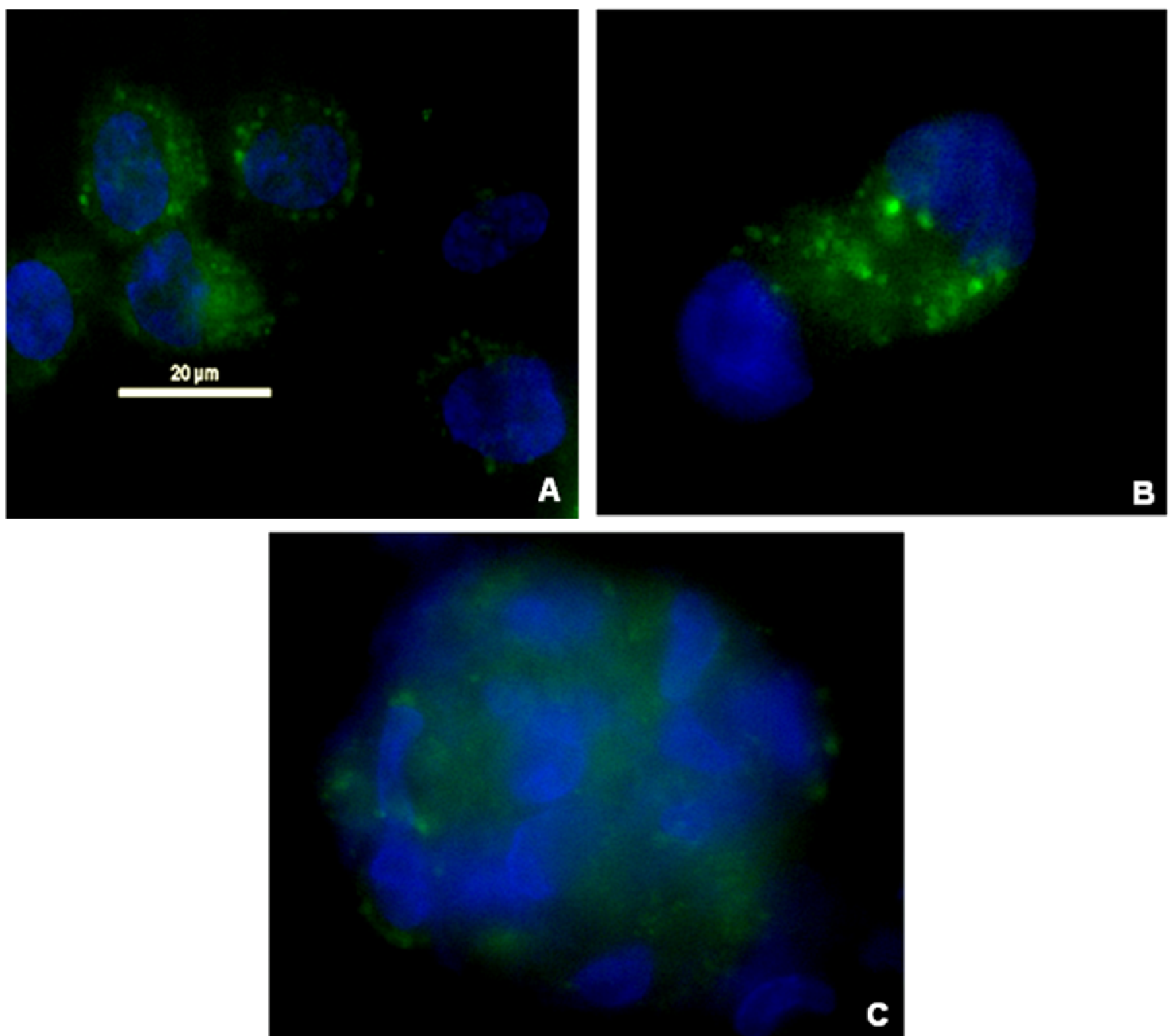

Expressão positiva de Calbindin nas CTIPD pós-diferenciação retinal. A-C) objetiva 100x. Núcleos corados com DAPI. 
- RECOVERIN: é uma proteína de fotorreceptores ligante de Cálcio, implicada na regulação da atividade da rodopsina quinase, uma enzima necessária para a adaptação luminosa. Nós encontramos poucas células que expressam esta proteína, porém com a técnica de imunofluorescência não é possível quantificar este valor. A marcação ocorre mais intensamente no citoplasma celular.

Figura 32 - Imunofluorescência - RECOVERIN
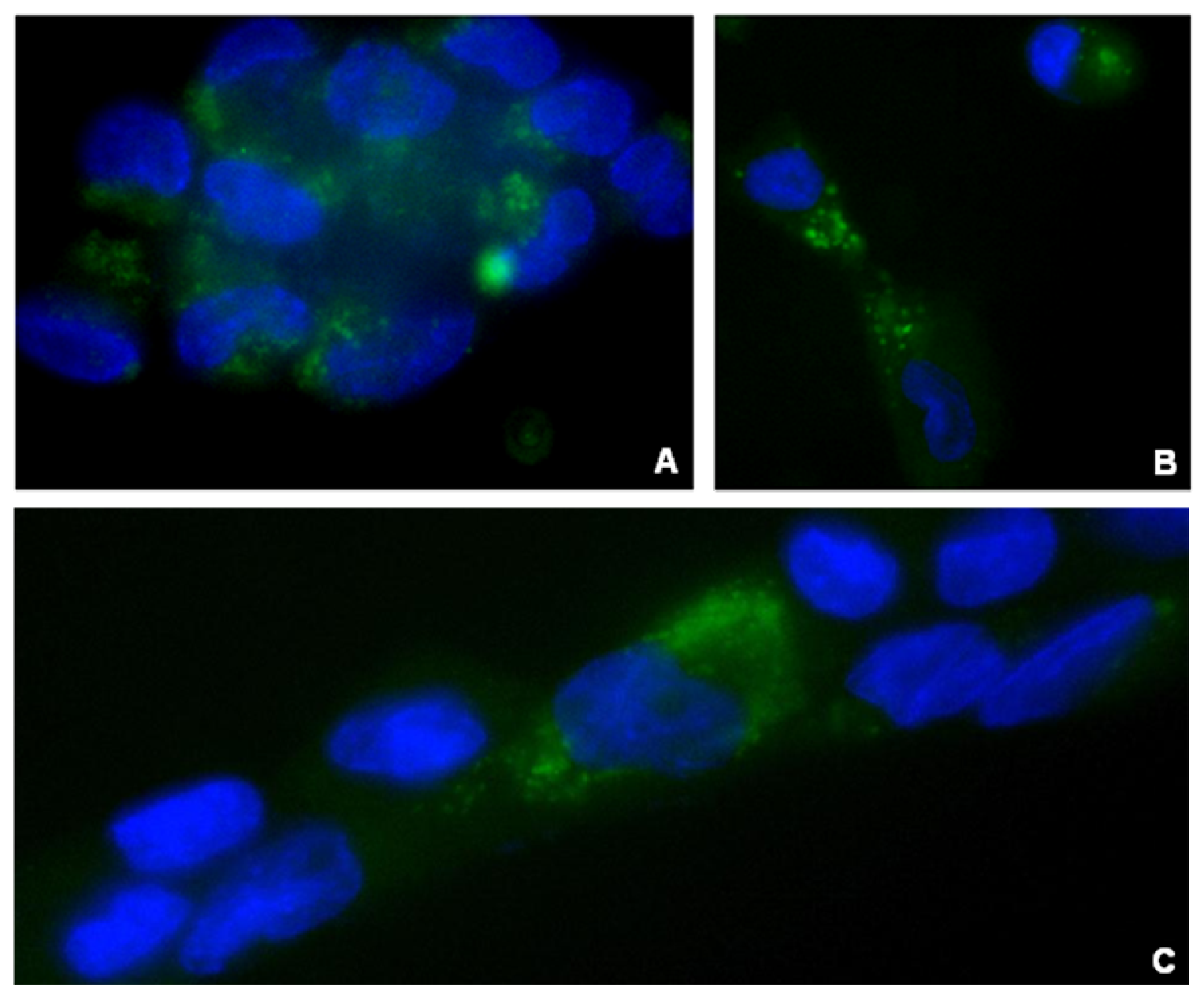

Expressão positiva de Recoverin nas CTIPD pós-diferenciação retinal. Apenas uma pequena porção das células expressa esta proteína, como fica evidente nas imagens. A-C) objetiva 100x. Núcleos corados com DAPI. 
- RHODOPSIN: é um pigmento visual dos fotorreceptores responsável pela absorção de fótons, mais especificamente, pela adaptação claro/escuro. Sua localização celular é mais citoplasmática, podendo também ser visualizada no núcleo. A quantidade de células que expressam esta proteína também foi bem menor em relação a expressão dos precursores retinais.

Figura 33 - Imunofluorescência - RHODOPSIN
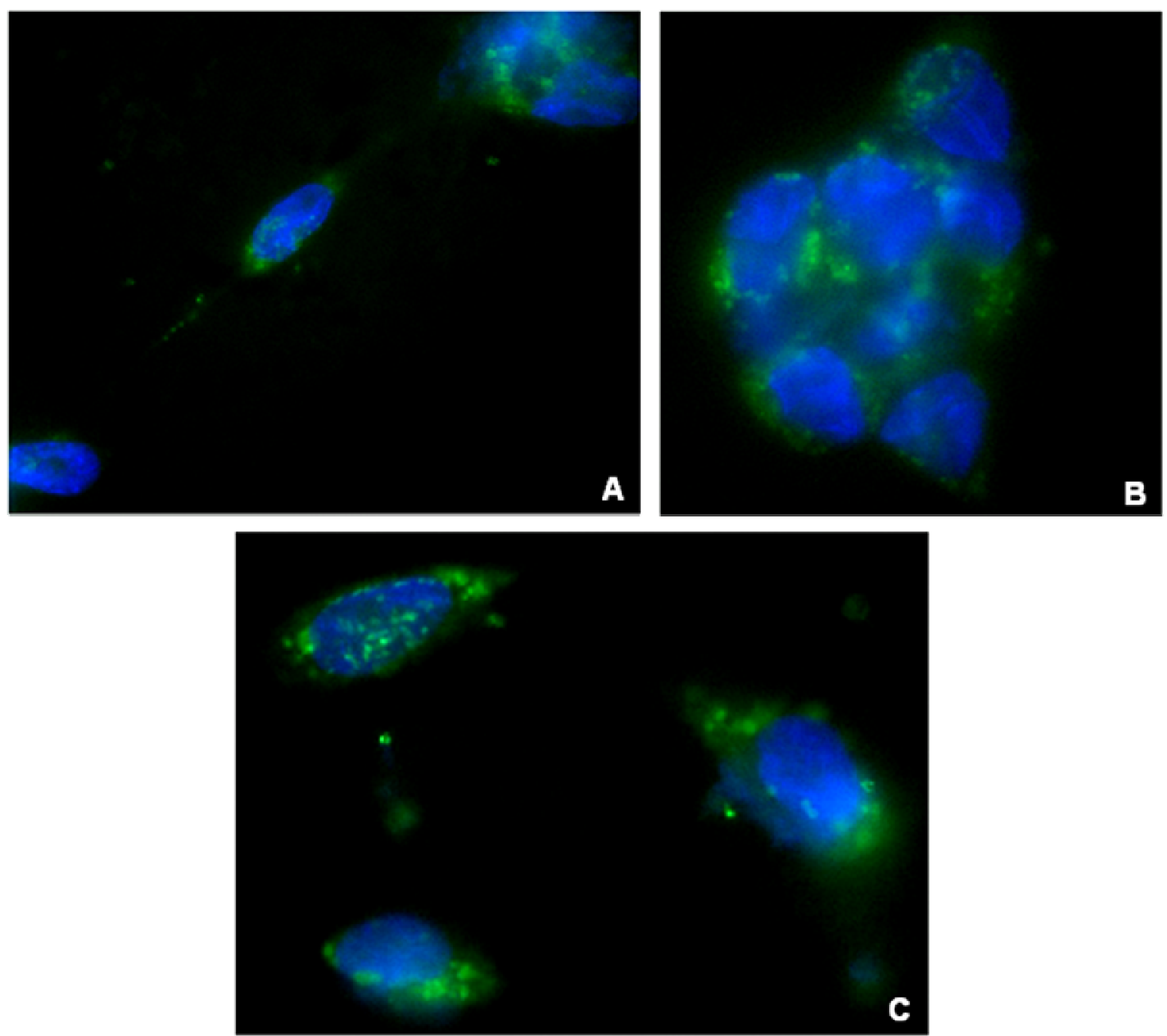

Expressão positiva de Rhodopsin nas CTIPD pós-diferenciação retinal. A-C) objetiva 100x. Núcleos corados com DAPI. 
6 DISCUSSÃO 
As patologias degenerativas retinianas podem levar à perda parcial ou completa da camada neurossensorial da retina, causando um dano irreversível na visão. Embora ainda não exista um método de prevenir ou tratar tais patologias, muitos estudos nessa área tem buscado o desenvolvimento de novas terapias capazes de contribuir nessa incessante busca pela recuperação da visão (ZHANG; WANG, 2010).

Nosso estudo teve por objetivo elaborar um protocolo de diferenciação das CTIPD em células semelhantes a neurônios retinais, in vitro, para desenvolvimento de uma futura terapia celular em degenerações retinianas. O desenvolvimento deste protocolo incluiu duas etapas de diferenciação: primeiramente foram obtidas neuroesferas compostas de células precursoras neuronais e retinais e em seguida induzimos a diferenciação destas células precursoras em neurônios retinais. A primeira etapa do protocolo que é a obtenção de células precursoras retinais já nos fornece grandes avanços no que diz respeito à aplicação terapêutica destas células. Porém na tentativa de verificar a capacidade das CTIPD em originar neurônios retinais maduros, terminalmente diferenciados, foi desenvolvida a segunda etapa.

O presente projeto foi bastante desafiador uma vez que não existem dados contundentes na literatura sobre a capacidade das CTA de se diferenciarem em neurônios retinais. Sendo assim, a utilização das CTA é um grande diferencial do nosso estudo, pois se por um lado esta população celular contribui para evitarmos a formação tumoral e a imunogenicidade pertinente às CT embrionárias, por outro lado, as CTA apresentam potencial mais limitado de diferenciação quando comparadas com CTE. Embora essa limitação na capacidade de diferenciação das CTA seja motivo de questionamento entre pesquisadores, acreditamos no potencial de diferenciação das CTIPD pelos resultados já comprovados pelo nosso grupo em trabalhos anteriores, os quais demonstraram a capacidade das CTIPD em se diferenciar para as linhagens osteogênica, adipogênica e condrogênica (GOMES et al., 2010; KERKIS et al., 2008; MONTEIRO et al., 2009) além do potencial de diferenciação para linhagem neuronal (ALMEIDA et al., 2011; KERKIS et al., 2006).

As CTIPD, previamente estabelecidas pelo nosso grupo (KERKIS et al., 2006; LIZIER et al., 2012), foram caracterizadas por imunofluorescência e citometria de fluxo para verificarmos se nesta população indiferenciada havia expressão de marcadores de precursores retinais como Pax-6, Chx-10, bem como de neurônios retinais em desenvolvimento e também maduros como Crx, Nrl, Calbindin e Rhodopsin. Como já era esperado, as CTIPD indiferenciadas foram negativas para expressão de todos os marcadores testados o que funciona para nós como um controle do processo de diferenciação das mesmas. A reação com o anticorpo anti-vimentina, embora já estudada por Lizier et al. (2012) na caracterização das 
CTIPD, foi realizada a fim de confirmarmos a natureza das CT utilizadas e como um controle positivo da reação de imunofluorescência. A vimentina é um marcador de citoesqueleto de células mesenquimais, estrutura essencial para a estabilidade celular (ERIKSSON et al., 1993).

Ainda com as CTIPD no estado indiferenciado, constatamos a expressão de CD73, um marcador descrito por Koso et al. (2009) como precursor comum de fotorreceptores cones e bastonetes em células retinais, tanto em camundongos como em primatas. Sua expressão estaria geneticamente localizada entre Crx e Nrl. Este marcador foi também expresso em células induzidas pluripotentes derivadas das CTIPD assim como nas CTE utilizadas como controle (BELTRÃO-BRAGA et al., 2012). Adicionalmente, Suzuki et al. (2012), observou a expressão positiva deste marcador em células pluripotentes induzidas de camundongos. Diferentemente destes trabalhos, nós observamos a expressão deste marcador em todas as CTIPD indiferenciadas, independente delas expressarem ou não Crx e Nrl. A avaliação deste marcador após o processo de diferenciação será detalhada a seguir.

Na primeira etapa do processo de diferenciação, nosso estudo concluiu que as CTIPD foram capazes de se agregar em neuroesferas, expressando marcadores da linhagem neuronal como Nestin e $\beta$-III-Tubulin em condições livres de soro em um tempo menor que o verificado pelo trabalho de Chiou et al. (2005). Nestin é uma proteína de filamento intermediário presente em progenitores neurais e células neuroepiteliais. A síntese de nestin decresce com a maturação da diferenciação enquanto outras proteínas de neurofilamento começam a ser expressas (LOTHIAN et al., 1997). A $\beta$-III-Tubulin é uma proteína presente em progenitores neurais e neurônios imaturos, sendo sua síntese diminuída com a maturação do processo de diferenciação. Nós pudemos observar nas neuroesferas, que a expressão de nestin ocorre somente no centro do agregado celular e à medida que estas células vão se direcionando para a periferia da esfera, esta expressão é diminuída ou ausente. O inverso ocorre com a $\beta$-III-Tubulin, a qual é mais expressa na periferia do esferoide, demonstrando a maturação neural que está ocorrendo do centro para a periferia. Embora a $\beta$-III-Tubulin, seja um marcador para neurônios imaturos, no processo de diferenciação, sua expressão ocorre mais tardiamente que a expressão de nestin. Tais resultados são consistentes com os observados por Hermann et al. (2004), bem como com o que foi observado pelo nosso grupo nas esferas obtidas a partir de CTE de camundongo diferenciadas em células neuronais (HAYASHI et al., 2010).

Os resultados verificados na microscopia eletrônica de transmissão foram compatíveis com os resultados observados na neuroesfera. Dentre células não diferenciadas, observamos 
algumas já em início de diferenciação, sendo consideradas células precursoras. Isso ficou evidente pela presença de células com alta razão entre núcleo e citoplasma, pobre em organelas e também pela formação de junções do tipo gap, as quais não estão presentes em células mesenquimais, mas que são típicas em células neuroepiteliais. Outra característica de células neuroepiteliais é a presença de microvilosidades observadas em bastante quantidade nas nossas células. Isso demonstra, por outro método, que as células da neuroesfera estão em início de comprometimento com a linhagem neuroepitelial que dá origem às células neuronais e retinais.

Os marcadores utilizados para avaliar a diferenciação, tanto em neuroesferas como em neurônios retinais, foram selecionados de acordo com trabalhos de grande relevância publicados na área (MACLAREN; PEARSON, 2007; OSAKADA et al., 2008, 2009). O gene Pax-6 codifica um fator de transcrição que controla o desenvolvimento ocular e quando parcialmente deficiente leva a aniridia, ou seja, ausência da íris do olho. Halder, Callaerts e Gehring (1995), demonstraram que o gene Pax-6 pode induzir a geração ectópica de um olho inteiro quando expressado no tórax de drosófilas, demonstrando a importância deste gene sobre o desenvolvimento ocular. Chx-10 é um dos primeiros marcadores associados com a formação da vesícula óptica na retina neural. Uma mutação nesse gene pode causar microftalmia, ou seja, a presença de um globo ocular de tamanho menor que o normal (FERDA et al., 2000). Crx e Nrl são os principais fatores de transcrição envolvidos na geração de fotorreceptores até o momento. O gene Crx é expresso em fotorreceptores tanto na retina em desenvolvimento, como madura, enquanto o $\mathrm{Nrl}$ é expresso exclusivamente em fotorreceptores bastonetes e é indispensável para o desenvolvimento e manutenção destes (FURUKAWA et al., 1997; MEARS et al., 2001). Calbindin é primeiramente associado a neurônios de axônios longos como os neurônios retinais, mas também pode ser expresso em outros tipos celulares. $\mathrm{O}$ nome Calbindin se refere a várias proteínas ligantes ao cálcio (do inglês calcium-binding). É um factor determinante no controle da dinâmica sináptica do $\mathrm{Ca}^{2+}$, presumivelmente com forte impacto sobre a plasticidade e processamento de informação em células neuronais (SCHMIDT, 2012). A expressão isolada deste marcador não pode ser considerada uma evidência da diferenciação retinal, somente quando associada à expressão de outros marcadores característicos de neurônios retinais. Rhodopsin é uma cromoproteína ou um pigmento encontrado em células fotorreceptoras da retina, responsável pela adaptação visual em ambientes de pouca luz. Quando exposto à luz, este pigmento é degradado e após um intervalo de tempo no escuro, ele retorna a sua forma original. Uma mutação no gene rhodopsin pode levar à retinose pigmentar. 
Figura 34 - Marcadores Expressos Durante o Desenvolvimento Ocular

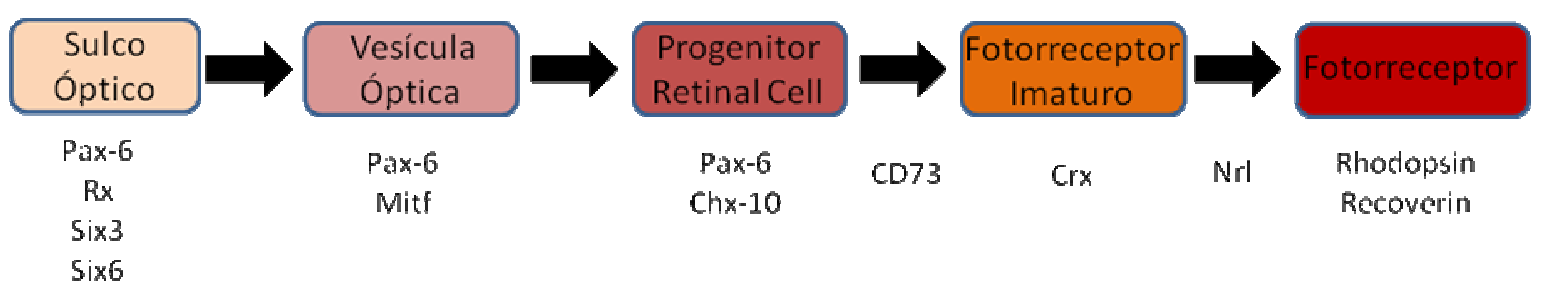

Esquema representando os marcadores expressos em cada fase do desenvolvimento ocular humano.

Após a obtenção das neuroesferas em suspensão, foram necessárias algumas alterações no protocolo que permitissem a adesão destas estruturas à lamínula ou placa de Petri, tanto para a avaliação da esfera formada como para continuação do processo de diferenciação. De acordo com o esperado, as esferas se fixaram em menos de 24 horas e começaram a liberar células. Em cinco dias já foi possível visualizar uma grande quantidade de células ao redor das esferas assim como demonstrado por Chiou et al. (2005). Realizamos então a coloração de HE, a qual foi uma ferramenta valiosa para a visualização do processo de diferenciação, uma vez que foi possível evidenciar a morfologia dos tipos celulares encontrados, bem como a emissão de prolongamentos intercelulares, formando uma rede celular característica da linhagem neural.

Além dos marcadores da linhagem neural, quando acrescentamos ácido retinóico ao protocolo de obtenção das neuroesferas, pudemos observar a expressão de um importante fator de transcrição, o Pax-6. O ácido retinóico, derivado da vitamina A ou retinol, é um conhecido indutor da diferenciação retinal e um elemento crítico para o desenvolvimento do olho e da função visual (KAM et al., 2012). O padrão de expressão do Pax-6 foi semelhante ao descrito por Meyer et al. (2009), no qual as células positivas estão localizadas no interior da esfera, comprovando que apesar de "pré-diferenciadas" em neurônios retinais-símile, elas se mantém imaturas e com capacidade de levar a diferenciação a termo.

$\mathrm{Na}$ segunda e última etapa do projeto, que foi a diferenciação retinal a partir das neuroesferas obtidas, realizamos diversos testes para desenvolvimento de um protocolo efetivo de diferenciação. Primeiramente, as neuroesferas foram submetidas ao co-cultivo sobre células do EPR inativadas, na tentativa de que as células epiteliais da retina pudessem liberar fatores indutores no processo de diferenciação, como verificado por Dunn et al. (1996). O teste foi realizado com dois diferentes meios de cultivo que atuaram de maneira bastante distinta quanto à morfologia celular, sendo mais satisfatória a morfologia das células cultivadas em meio neurobasal. Porém, com 10 dias de co-cultivo, a esfera tinha liberado 
todas as suas células, se desfazendo sobre o EPR, como se estivesse se fundindo às células epiteliais. Desta maneira, concluímos que este não seria um método adequado para estabelecimento de um protocolo de diferenciação.

Como um método alternativo para a diferenciação retinal, as neuroesferas foram desagregadas e plaqueadas em seis diferentes meios de cultivo. A avaliação morfológica das células apontou o meio condicionado pelo EPR, com e sem indutores, como o meio de cultivo mais adequado para a diferenciação, embora o resultado com todos os meios testados não tenha sido totalmente satisfatório. Seguindo com este protocolo de diferenciação, pudemos notar que estabelecer um protocolo utilizando um meio condicionado não era a maneira ideal para identificar os reais agentes indutores, pois não conhecemos a constituição daquele meio e sua composição pode variar muito de acordo com as condições de cultivo do EPR. Assim, optamos por não mais utilizar o EPR como estímulo para diferenciação retinal e partir para testes com meios e indutores apenas comerciais.

Uma tentativa de diferenciação retinal evitando a passagem pelo estágio de neuroesfera foi realizada a fim de verificarmos a real necessidade desta etapa e também visando uma diminuição no tempo de diferenciação. Morfologicamente a cultura adquiriu características de células neurais, como perda de citoplasma, núcleos deslocados e refringentes, emissão de prolongamentos e conexões intercelulares, porém o resultado da imunofluorescência demonstrou que tais células não apresentaram expressão de nenhum marcador de diferenciação retinal, sendo positivas apenas para expressão de GFAP e $\beta$-IIITubulina. Isso demonstra que este processo de diferenciação direta pode ser adequado para o desenvolvimento de células neuronais, mais especificamente células gliais, porém o mesmo não foi eficiente na geração de células retinais. Sendo assim, voltamos a avaliar protocolos que incluíssem o estágio de neuroesfera, como inicialmente programado.

O processo de diferenciação das neuroesferas em neurônios retinais foi bastante complexo, dado o alto grau de especialização destas células somado à capacidade de diferenciação mais restrita das CTA, porém após diversos protocolos testados, pudemos observar não só morfologicamente, como também por imunofluorescência que nossas células passaram a expressar alguns marcadores específicos da diferenciação retinal. Inicialmente e em maior intensidade e quantidade, verificamos a expressão de Chx-10, um precursor retinal e Crx, o qual é considerado um precursor de fotorreceptores. Observamos também, porém numa quantidade bem menor, a expressão de alguns marcadores mais maduros da diferenciação retinal, como Nrl, Calbindin, Recoverin e Rhodopsin. Podemos supor com tais resultados que o processo de diferenciação se encontra numa fase de transição entre precursores e neurônios 
retinais maduros, até mesmo porque o próprio processo de diferenciação não ocorre de maneira sincronizada, ou seja, cada célula tem um tempo específico de resposta àquele determinado estímulo.

A expressão positiva do CD73 após a diferenciação é mais um indicativo do estágio em que o processo de diferenciação se encontra. Como pôde ser observado, a expressão de CD73 foi bastante intensa e em grande parte das células e segundo, Koso et al. (2009) sua localização estaria geneticamente situada entre a expressão de Crx e Nrl. Isso condiz com os nossos resultados, onde observamos uma intensa expressão de Crx e uma fraca expressão de Nrl. Desta maneira, temos fortes indícios de que nossa diferenciação retinal está nesta fase de transição entre precursores e fotorreceptores maduros.

Após o estudo de diversos trabalhos, tanto de diferenciação retinal, como da aplicação clínica destas células, pudemos notar a importância da diferenciação em células precursoras. Um precursor é uma célula já comprometida com determinada linhagem, porém mantém seu potencial de proliferação ativo e com boa capacidade migratória, que são quesitos fundamentais para uma boa enxertia no tecido hospedeiro. A célula totalmente especializada tem sua vantagem clínica, pois a injeção estaria ocorrendo com as células específicas que o paciente necessita, porém sem essa capacidade de dar origem a novas células ou de migrar para o local exato da lesão. Idealmente, uma aplicação clínica deveria contar com esses dois tipos celulares; a célula precursora, bem como, a célula madura, para um melhor resultado in vivo. Porém não podemos deixar de citar que as doenças degenerativas da retina são diferentes umas das outras, e os pacientes também variam quanto à idade, fase e grau de comprometimento da doença e será difícil que um único tratamento se aplique a todas as doenças em suas diferentes fases clínicas.

Desta forma podemos concluir que atingimos um grande avanço na diferenciação das CTIPD em células precursoras retinais. Porém, nosso estudo somente poderá ser validado quando os ensaios funcionais forem realizados, primeiramente demonstrando a capacidade das células de se integrarem, anatômica e funcionalmente com as células retinais (nicho) em modelos animais saudáveis. Se estas células puderem migrar e se diferenciar em fotorreceptores dentro deste ambiente saudável, teremos atingido a primeira etapa de comprovação do estado funcional das células retinais derivadas das CTIPD. Assim também estabelecemos um modelo de controle positivo para futuros ensaios com a utilização destas células em animais que possuem doenças degenerativas da retina. 
7 CONCLUSÕES 
De acordo com os resultados demonstrados no presente trabalho, podemos concluir que:

- as CTIPD foram capazes de formar as estruturas semelhantes às neuroesferas in vitro, podendo ser mantidas em cultura, tanto em suspensão como aderidas, por longos períodos;

- as neuroesferas, quando aderidas na placa de cultivo, liberaram células com morfologia semelhante à células neuronais e expressaram marcadores característicos desta linhagem (nestin e $\beta$-III-Tubulin), demonstrando o início de um comprometimento neural;

- simultaneamente, as neuroesferas expressaram um marcador de progenitor retinal (Pax6), sugerindo que neste estágio, já é possível indicarmos o início do comprometimento retinal;

- pudemos concluir também que a diferenciação retinal, utilizando co-cultivo ou meio condicionado pelo EPR, pode não ser uma alternativa viável, pois não é possível identificar os reais agentes indutores, sendo estes muito variáveis de acordo com as condições de cultivo do EPR;

- a tentativa de diferenciação retinal das CTIPD evitando o estágio de neuroesfera, não foi satisfatória, pois foram geradas apenas células com características neurais, em sua maioria, células gliais, porém sem expressão para os marcadores retinais;

- utilizando o marcador CD73 demonstramos que a transição mesenquima-epitélio ocorre nas CTIPD conforme a diferenciação acontece. As CTIPD CD73+ após o processo de diferenciação, se agrupam em grumos e apresentam características de células epiteliais justapostas com microvilosidades, como foi também demonstrado pela microscopia eletrônica;

- a imunofluorescência nas células diferenciadas apresentou resultados bastante significantes, expressando intensamente os marcadores de precursores retinais e com 
menos intensidade, mas também positivos, os marcadores de neurônios retinais maduros. Isso demonstra que nosso protocolo foi efetivo na geração de células comprometidas com a linhagem retinal em diversos estágios de maturação.

Desta forma podemos concluir que atingimos um grande avanço na diferenciação das CTIPD em células precursoras retinais. Porém, nosso estudo somente poderá ser validado quando os ensaios funcionais forem realizados, primeiramente demonstrando a capacidade das células de se integrarem, anatômica e funcionalmente com as células retinais (nicho) em modelos animais saudáveis. 
REFERÊNCIAS

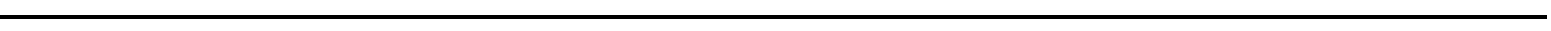




\section{REFERÊNCIAS $^{1}$}

ALMEIDA, F. M. et al. Human dental pulp cells: a new source of cell therapy in a mouse model of compressive spinal cord injury. J. Neurotrauma, v. 9, p. 1939-1949, 2011. Epub 2011 Aug 8.

ALVARADO, S. A. Stem cells: time to check our premises. Cell Stem Cell, v. 3, n. 1, p. 2529,2008

BELTRÃO-BRAGA, P. I. et al. Feeder-free derivation of induced pluripotent stem cells from human immature dental pulp stem cells. Cell Transplant., 2011.

BRACK, A. S. et al. Increased Wnt signaling during aging alters muscle stem cell fate and increases fibrosis. Science, v. 7, p. 807-810, 2007.

BRINGMANN, A.; REICHENBACH, A. Role of Muller cells in retinal degenerations. Front. Biosci., v. 6, p. 72-92, 2001.

BULL, N. D.; MARTIN, K. R. Concise review: toward stem cell-based therapies for retinal neurodegenerative diseases. Stem Cells, v. 29, p. 1170-1175, 2011.

CAPLAN, A. I. Mesenchymal Stem Cells. J. Orthop. Res., v. 9, p. 641-650, 1991.

CAPLAN, A. I. Tissue engineering design for the future: new logics, old molecules. Tissue Engineering, v. 6, p. 1-8, 2000.

CAPLAN, A. I. Design parameters for function tissue engineering. Functional Tissue Engineering, v. 6, p. 129-138, 2003.

CAPLAN, A. I. Mesenchymal stem cells: cells-based reconstructive therapy in orthopedics. Tissue Engineering, v. 11, p. 1198-1211, 2005.

CHIOU, S. H. et al. A novel in vitro retinal differentiation model by co-culturing adult human bone marrow stem cells with retinal pigmented epithelium cells. Biochem. Biophys. Res. Commun., v. 3, p. 578-585, 2005.

CONGDON, N. G.; FRIEDMAN, D. S.; LIETMAN T. Important causes of visual impairment in the world today. JAMA, v. 8, p. 2057-2060, 2003.

CONSELHO BRASILEIRO DE OFTALMOLOGIA. Retinopatia Diabética. 2003. Disponível em: <http://www.umani.com.br/index.php/retinopatia-diabetica/>. Acesso em: 15 dez. 2011.

DAS, A. V. et al. Retinal properties and potencial of the adult mammalian ciliary epithelium stem cells. Vision Research, v. 2, p. 1653-1666, 2005.

\footnotetext{
${ }^{1}$ De acordo com:

ASSOCIAÇÃO BRASILEIRA DE NORMAS TÉCNICAS. NBR 6023: informação e documentação: referências: elaboração. Rio de Janeiro, 2002.
} 
DE FILIPPIS, L. et al. A novel, immortal, and multipotent human neural stem cell line generating functional neurons and oligodendrocytes. Stem Cells, v. 5, p. 2312-2321, 2007.

DORRELL, M. I. et al. Adult bone marrow-derived stem cells use R-cadherin to target sites of neovascularization in the developing retina. Blood, v. 1, p. 3420-3427, 2004.

DUNN, K. C. et al. ARPE-19, a human retinal pigment epithelial cell line with differentiated properties. Exp. Eye Res., v. 2, p. 155-169, 1996.

DURRUTY, P. et al. Evaluation of retinal involvement in type 2 diabetics with microalbuminuria. Rev. Med. Chil., v.3, p.1085-1092, 2000.

ERIKSSON, H. P. Genes knockout of C-src, transforming growth factor $\alpha 1$ and tenascin suggest superfluous nonfunctional expression proteins. J. Cell Biol., v. 1, p.1079-1081, 1993.

FERDA, P. E. et al. Human microphthalmia associated with mutations in the retinal homeobox gene CHX10. Nat. Genet., v.6, p.397-401, 2000.

FRYE, M.; FISHER, A. G.; WATT, F. M. Epidermal stem cells are defined by global histone modifications that are altered by Myc-induced differentiation. PLoS One, v. 2, 2007.

FURUKAWA, T.; MORROW E. M.; CEPKO C. L. Crx, a novel otx-like homeobox gene, shows photoreceptor-specific expression and regulates photoreceptor differentiation. Cell, v. 4, p. 531-541, 1997.

GOMES, J. A. et al. Corneal reconstruction with tissue-engineered cell sheets composed of human immature dental pulp stem cells. Invest. Ophthalmol. Vis. Sci., v. 2, p. 1408-1414, 2010 .

GONG, L. et al. Differentiation of rat mesenchymal stem cells transplanted into the subretinal space of sodium iodate-injected rats. Clinical and Experimental Ophthalmology, v.1, p. 666-671, 2008.

GRUPO RETINA SÃO PAULO. O olho humano. 2007. Disponível em: <http://www.gruporetina.org.br/olho.htm>. Acesso em: 15 dez. 2011.

HALDER, G.; CALLAERTS, P.; GEHRING, W. J. Induction of ectopic eyes by targeted expression of the eyeless gene in Drosophila. Science, v. 5, p. 1788-1792, 1995.

HAYASHI, M. A. et al. Long-term culture of mouse embryonic stem cell-derived adherent neurospheres and functional neurons. Tissue Eng. Part C Methods, v. 7, p. 1493-1502, 2010.

HERMANN, A. et al. Efficient generation of neural stem cell-like cells from adult human bone marrow stromal cells. J. Cell Sci., v. 8, p. 4411-4422, 2004.

HERZOG, E. L. et al. Plasticity of marrow-derived stem cells. Blood, v. 102, p. 3483-3493, 2003. 
HOPLEY, C. et al. Cost utility of photodynamic therapy for predominantly classic neovascular age related macular degeneration. Br. J. Ophthalmol., v. 88, p. 982-987, 2004.

ISOOLHOS. Retina: Degeneração macular relacionada à idade. 2005. Disponível em: <http://www.isoolhos.com.br/retina/>. Acesso em: 15 dez. 2011.

JIANG, Y. et al. Pluripotency of mesenchymal stem cells derived from adult marrow. Nature, v. 6, p. 41-49, 2002.

JONAS, J. B. et al. Intravitreal autologous bone marrow-derived mononuclear cell transplantation. Acta Ophthalmol., v. 1, p. 131-132, 2010.

JONG, P. T. Age-related macular degeneration. N. Engl. J. Med., v. 14, p. 1474-1485, 2006.

MELDAU, D. C.. Retina. 2010. Disponível em: 〈http://www.infoescola.com/visao/retina/>. Acesso em: 26 set. 2011.

KAM, R. K. et al. Retinoic acid synthesis and functions in early embryonic development. Cell Biosci., v. 2, 2012.

KERKIS, I. et al. Early transplantation of human immature dental pulp stem cells from baby teeth to golden retriever muscular dystrophy (GRMD) dogs: Local or systemic? J. Transl. Med., v. 8, 2008.

KERKIS, I. et al. Isolation and characterization of sub-population of dental pulp stem cells expressing OCT-4 and other key embryonic stem cells markers. Cells Tissues and Organs, v. 6, 2006.

KLASSEN, H.; SAKAGUCHI, D. S.; YOUNG, M. J. Stem cells and retinal repair. Prog. Retin. Eye Res., v. 3, p.149-181, 2004.

KOSO, H. et al. CD73, a novel cell surface antigen that characterizes retinal photoreceptor precursor cells. Investigative Ophthalmology \& Visual Science, v. 50, n. 11, p. 5411-5418, 2009.

LAMBA, D. A. et al. Efficient generation of retinal progenitor cells from human embryonic stem cells. Developmental Biology, v. 9, p. 12769-12774, 2006.

LAMBA, D. A. et al. Generation, purification and transplantation of photoreceptors derived from human induced pluripotent stem cells. PLoS One, v. 5, 2010.

LANCE. Células Tronco, o que são? 2010. Disponível em: <http://www.lanceufrj.org/ceacutelulas-tronco.html>. Acesso em: 12 abr. 2012.

LASLETT, A. L.; FILIPCZYK, A. A.; PERA, M. F. Characterization and culture of human embryonic stem cells. Trends Cardiovasc. Med., v. 19, p. 295-301, 2003. 
LEWIS, G. P.; FISHER, S. K. Up-regulation of glial fibrillary acidic protein in response to retinal injury: its potential role in glial remodeling and a comparison to vimentin expression. Int. Rev. Cytol., v. 5, p. 263-290, 2003.

LIVESEY, F. J.; CEPKO, C. L. Vertebrate neural cell-fate determination: lessons from the retina. Nature Reviews-Neuroscience, v. 4, p. 109-117, 2001.

LIZIER, N. F. et al. Scaling-up of dental pulp stem cells isolated from multiple niches. PLoS ONE, v. 7, 2012.

LHOTIAN, C.; LENDHAL, U. An evolutionary conserved region in the second intron of the human nestin gene direct gene expression to CNS progenitor cells and to early neural crest cells. Eur. J. Neurosci., v. 21, p. 452-462, 1997.

MACLAREN, R. E.; PEARSON, R. A. Stem cell therapy and the retina. Eye (Lond.), v. 10, p. 1352-1359, 2007.

MACLAREN, R. E. et al. Retinal repair by transplantation of photoreceptor precursors. Nature, v. 6, p. 203-207, 2006.

MARKIEWICZ, I. et al. Cellular environment directs differentiation of human umbilical cord blood-derived neural stem cells in vitro. J. Histochem. Cytochem., v. 59, p. 289-301, 2011. Epub 2011 Jan 12.

MARMOR, M. F. Retinal pigment epithelium. In: YANOFF, M.; DUKER, J. S. Ophthalmology. St Louis, MO: Mosby, 2004. v. 12, p. 775-778.

MEARS, A. J. et al. Nrl is required for rod photoreceptor development. Nat. Genet., v. 29, p. 447-452, 2001.

MENDONÇA COSTA, A. et al. Reconstruction of large cranial defects in nonimmunosuppressed experimental design with human dental pulp stem cells. J. Craniofac. Surg., v. 9, p. 204-210, 2008.

MEYER, J. S. et al. Modeling early retinal development with human embryonic and induced pluripotent stem cells. Proc. Natl. Acad. Sci. USA, v. 15, p. 16698-16703, 2009.

MONTEIRO, B. G. et al. Human immature dental pulp stem cells share key characteristic features with limbal stem cells. Cell Prolif., v. 4, p. 587-594, 2009.

MOSCOVICI, M. O potencial neural das células tronco imaturas da polpa dentária humana. In: LIZIER, N. F.; KERKIS, I. (Ed.). Temas de neurorregeneração. Campos do Jordão: Med Line, 2009. p. 113-115.

NAKAGAMI, H. et al. Adipose tissue-derived stromal cells as a novel option for regenerative cell therapy. Journal of Atherosclerosis and Thrombosis, v. 13, n. 2, p. 77-81, 2005.

OSAKADA, F. et al. Toward the generation of rod and cone photoreceptors from mouse, monkey and human embryonic stem cells. Nat. Biotechnol., v. 8, p. 215-224, 2008. 
OSAKADA, F. et al. In vitro differentiation of retinal cells from human pluripotent stem cells by small-molecule induction. J. Cell Sci., v. 17, p. 3169-3179, 2009.

PITTENGER, M. F.; MARTIN, B. J. Mesenchymal stem cells and their potential as cardiac therapeutics. Circ. Res., v. 95, n. 1, p. 9-20, 2004.

POZDNYAKOV, S. et al. Retina remodeling following diode laser. Can. J. Ophthalmol., v. 2, p. 203-207, 2008.

RYAN, S. J.; STOUT, J. T.; DUGEL, P. V. Posterior penetrating ocular trauma. In: RYAN, S. J. Retina, v. 32, p. 2235-2250, 1994.

RESNIKOFF, S. et al. Global data on visual impairment in the year 2002. Bull. World Health Organ., v. 5, p. 844-851, 2004.

SAKAGUCHI, D. S. et al. Transplantation of neural progenitor cells into the developing retina of the Brazilian opossum: an in vivo system for studying stem/progenitor cell plasticity. Dev. Neurosci., v. 15, p. 336-345, 2004.

SALOMÃO, S. R.; MITSUHIRO, M. R. K. H.; BELFORT JUNIOR, R. Visual impairment and blindness: an overview of prevalence and causes in Brazil. Anais da Academia Brasileira de Ciências, v. 1, p. 539-549, 2009.

SCHMIDT, H. Three functional facets of calbindin D-28k. Front. Mol. Neurosci., 2012. Epub 2012 Mar 15.

SCHUBERT, H. D. Structure and function of the neural retina. In: Yanoff M., Duker J.S. Ophthalmology, St Louis, MO, Mosby; v. 7, p. 771-774, 2004.

SIEIRO, R. Retinose Pigmentar. 2006. Disponível em: $<$ http://www.laservisao.com.br/doencas.php?tit=Doen\%E7as\&codigo=21>. Acesso em 16 dez. 2011.

SIQUEIRA DA FONSECA, S. A. et al. Human immature dental pulp stem cells' contribution to developing mouse embryos: production of human/mouse preterm chimaeras. Cell Prolif., v. 9, p. 132-140, 2009.

SIQUEIRA, R. C. Terapia celular nas doenças oftalmológicas. Rev. Bras. Hematol. Hemoter., v. 4, p. 120-127, 2009.

SIQUEIRA, R. C. et al. Intravitreal injection of autologous bone marrow-derived mononuclear cells for hereditary retinal dystrophy: a phase I trial. Retina, v. 2, p. 1207-1214, 2011.

SLATTER, D. Retina: fundamentos de oftalmologia veterinária. 3. ed. São Paulo: Roca, 2005. v. 16, p. 451-488. 
SUZUKI, N. et al. Establishment of retinal progenitor cell clones by transfection with Pax6 gene of mouse induced pluripotent stem (iPS) cells. Neurosci. Lett., v. 6, p. 116-121, 2012. Epub 2012 Jan 3.

TAKAHASHI, M. et al. Widespread integration and survival of adult-derived neural progenitor cells in the developing optic retina. Mol. Cell Neurosci., v. 43, p. 340-348, 1998.

THOMSON, J. A. et al. Embryonic stem cell lines derived from human blastocysts. Science, v. 5, p. 1145-1147, 1998.

TOHMA, Y. et al. Bone marrow-derived mesenchymal cells can rescue osteogenic capacity of devitalized autologous bone. Journal of Tissue Engineering and Regenerative Medicine, v. 2, p. 61-68, 2008.

TUCKER, B. A. et al. Transplantation of adult mouse iPS cell-derived photoreceptor precursors restores retinal structure and function in degenerative mice. PLoS One, v. 6, 2011.

VECINO, E. Gene therapy against retinosis pigmentary. Arch. Soc. Esp. Oftalmol., v. 83, p. 213-214, 2008.

WANG, S. et al. Non-invasive stem cell therapy in a rat model for retinal degeneration and vascular pathology. PLoS One, v. 5, 2010.

WIKIMEDIA COMMONS. All Things Stem Cell. 2009. Disponível em: <http://www.allthingsstemcell.com/glossary/>. Acesso em: 18 mar. 2012.

XUFANG, S.; HUANRONG, J.; HONG, Y. In vitro culture of bone marrow mesenchymal stem cells in rats and differentiation into retinal neural-like cells*. Journal of Huazhong University of Science and Technology, v. 12, p. 598-600, 2007.

ZHANG, Y.; WANG, W. Effects of bone marrow mesenchymal stem cell transplantation on light-damaged retina. Invest. Ophthalmol. Vis. Sci., v. 3, p. 3742-3748, 2010.

ZHOU L, et al. Differentiation of induced pluripotent stem cells of Swine into rod photoreceptors and their integration into the retina. Stem Cells, v. 13, p. 972-980, 2011.

ZUK, P. A.; ZHU, M.; MIZUNO, H. Multi-lineage cells from human adipose tissue: implication for cell-based therapies. Tissue Engineering, v. 7, p. 211-228, 2001.

ZUK, P. A. et al. Human adipose tissue is a source of multipotent stem cells. Molecular Biology of the Cell, v. 13, p. 4279-4295, 2002. 
APÊNDICE - Quadros 
Quadro 1 - Anticorpos Primários

\begin{tabular}{|llll|}
\hline Anticorpo & Origem & Diluição & Fabricante \\
\hline CD73 & Mouse & $1: 100$ & $*$ \\
Vimentina & Mouse & $1: 100$ & Santa Cruz Biotechnology \\
Pax-6 & Goat & $1: 100$ & Santa Cruz Biotechnology \\
Chx-10 & Goat & $1: 100$ & Santa Cruz Biotechnology \\
Crx & Rabbit & $1: 100$ & Santa Cruz Biotechnology \\
Nrl & Rabbit & $1: 100$ & Santa Cruz Biotechnology \\
Calbindin & Rabbit & $1: 100$ & Santa Cruz Biotechnology \\
Recoverin & Goat & $1: 100$ & Santa Cruz Biotechnology \\
Rhodopsin & Rabbit & $1: 100$ & Santa Cruz Biotechnology \\
\hline Gentilmente cedido pelo Dr. Arnold Caplan - Case Western Reserve
\end{tabular}

Quadro 2 - Anticorpos Primários - Linhagem Neural

\begin{tabular}{|llll|}
\hline Anticorpo & Origem & \multicolumn{1}{c}{ Diluição } & \multicolumn{1}{c|}{ Fabricante } \\
\hline Nestin & Goat & $1=100$ & Santa Cruz Biotechnology \\
Beta-III-Tubulin & Mouse & $1=100$ & Chemicon \\
GFAP & Goat & $1=100$ & Santa Cruz Biotechnology \\
\hline
\end{tabular}

Quadro 3 - Anticorpos Secundários

\begin{tabular}{|lccc|}
\hline Anticorpo & Origem & Diluição & Fabricante \\
\hline FITC anti-goat & Rabbit & $1: 200$ & Santa Cruz Biotechnology \\
FITC anti-mouse & Goat & $1: 200$ & Santa Cruz Biotechnology \\
FITC anti-rabbit & Goat & $1: 200$ & Santa Cruz Biotechnology \\
\hline
\end{tabular}

